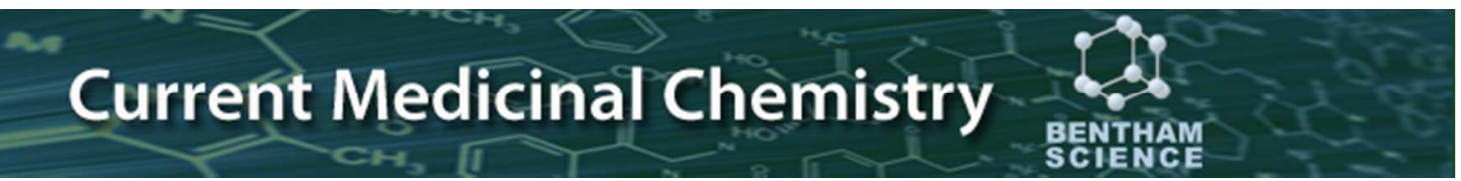

\title{
Innovative Therapeutic Potential of Cannabinoid Receptors as Targets in Alzheimer's disease and Less Well-Known Diseases
}

\begin{tabular}{|r|l|}
\hline Journal: & Current Medicinal Chemistry \\
\hline Manuscript ID & CMC-2017-0573.R1 \\
\hline Manuscript Type: & Review \\
\hline Date Submitted by the Author: & n/a \\
\hline Complete List of Authors: & Páez, Juan A.; IQM \\
& Campillo, Nuria; Centro de Investigaciones Biológicas-CSIC, \\
\hline \multicolumn{2}{|l}{} \\
\hline & $\begin{array}{l}\text { Alzheimer's disease, CB2 agonist, Endocannabinoid system (eCS), Bone } \\
\text { disorders, Cardiovascular diseases, Austism disorders }\end{array}$ \\
\hline Note: The following files were submitted by the author for peer review, but cannot be converted to \\
PDF. You must view these files (e.g. movies) online. \\
\hline Fig1.cdx \\
Fig2.cdx \\
Fig4.cdx \\
Fig5.cdx \\
Fig6.cdx \\
Fig7.cdx \\
Fig8.cdx \\
Fig9.cdx \\
Fig10.cdx \\
Fig11.cdx \\
Fig12.cdx \\
Fig13.cdx \\
Fig14.cdx \\
Fig15.cdx \\
Fig16.cdx \\
Fig17.cdx \\
\hline
\end{tabular}


Innovative Therapeutic Potential of Cannabinoid Receptors as Targets in Alzheimer's disease and Less Well-Known Diseases

J. A. Páez ${ }^{* a}$ and N. E. Campillo*b

${ }^{a}$ Instituto de Química Médica (IQM-CSIC). C/ Juan de la Cierva, 3, 28006, Madrid, Spain

${ }^{\mathrm{b}}$ Centro de Investigaciones Biológicas (CIB-CSIC). C/ Ramiro de Maeztu, 9, 28040, Madrid, Spain

\section{Correspondence:}

\section{J. A. Páez}

Instituto de Química Médica (IQM-CSIC).

C/ Juan de la Cierva, 3, 28006, Madrid, Spain

jpaez@iqm.csic.es

\section{N. E. Campillo}

Centro de Investigaciones Biológicas (CIB-CSIC).

C/ Ramiro de Maeztu, 9, 28040, Madrid, Spain

nuria.campillo@csic.es 


\begin{abstract}
The discovery of cannabinoid receptors at the beginning of the 1990s, CB1 being cloned in 1990 and CB2 cloned in 1993, and the availability of selective and potent cannabimimetics could only be justified by the existence of endogenous ligands that are capable of binding to them. Thus, the characterisation and cloning of the first cannabinoid receptor (CB1) led to the isolation and characterisation of the first endocannabinoid, arachidonoylethanolamide (AEA), two years later and the subsequent identification of a family of lipid transmitters known as the fatty acid ester 2arachidonoylglycerol (2-AG).

The endogenous cannabinoid system is a complex signalling system that comprises transmembrane endocannabinoid receptors, their endogenous ligands (the endocannabinoids), the specific uptake mechanisms and the enzymatic systems related to their biosynthesis and degradation.

The endocannabinoid system has been implicated in a wide diversity of biological processes, in both the central and peripheral nervous systems, including memory, learning, neuronal development, stress and emotions, food intake, energy regulation, peripheral metabolism, and the regulation of hormonal balance through the endocrine system.

In this context, this article will review the current knowledge of the therapeutic potential of cannabinoid receptor as a target in Alzheimer's disease and other less well-known diseases that include, among others, multiple sclerosis, bone metabolism, and Fragile X syndrome.

The therapeutic applications will be addressed through the study of cannabinoid agonists acting as single drugs and multi-target drugs highlighting the CB2 receptor agonist.
\end{abstract}

Keywords: Alzheimer's disease, CB2 agonist, endocannabinoid system (eCS), bone disorders, Autism disorders, cardiovascular diseases 


\section{Introduction}

The hemp plant has been used medicinally and recreationally from Antiquity. Most authors have located Central Asia as the possible origin of this plant, although the geographic situation is too ambiguous.

It was known in China almost five thousand years ago, when it was used to obtain fibre and oil. The earliest documented uses of hemp in China date from 4000 B.C. [1,2]. Hemp thread and rope have also been found in Turkestan since 3000 B.C. [3]. In addition, hemp cloth and paper were found in the grave of Emperor Wu (Han Dynasty 104-87 B.C.) by Ts'ai Lun. The hemp paper also was frequently used by Tibetans to write their monastic histories due to their durability and quality [3].

Cannabis grain was chosen as one of the "five grains", together with rice, barley, millet and soy beans [2], and is still a source of cooking oil and grain in areas of Nepal [3]. Cannabis may be the oldest plant that is not grown specifically for use as food. However, the location of the first cannabis crops is unclear [3].

There is archaeological evidence that the Scythians of southern Central Asia used the plant during funeral rites as hemp seeds have been in metal tripod censers; for example, Herodotus described this more than 2,000 years ago. The discovery of leaves and fruits of hemp in the Yanghai Tombs (Turpan District in Xinjiang, China), dated by $14 \mathrm{C}$ at 2500 years B.C., provides evidence about the ancient utilisation of Cannabis in China for ritual/medicinal purposes [4].

Pen Ts'ao Ching compiled the herbal around 100 A.D., but this was attributed to the legendary emperor Shen-Nung, (2700 B.C.); this provides evidence that the Chinese knew of its psychotropic properties and therefore of medical cannabis use in China [3].

In India, it formed part of certain religious rites, and was used for its curative properties. The medicinal use of Cannabis was referred to in India in the medical work Susrita, which was compiled around 1000 B.C. and was later recorded in ancient Persia, in about 600 B.C., in the Sanskrit work Zend Avesta [3].

The hallucinogenic use of cannabis seems to be associated with indigenous central Asian shamanistic practices. However, medicinal use was probably not originally distinguished from religious use. In the Atharva Veda (1200 to 1000 B.C.), cannabis was collected as one of the five sacred plants. It was traditionally considered sacred in Tibet and used to facilitate meditation and highlight consciousness in all aspects of the ceremony. There is no evidence regarding the use of psychotropic properties of cannabis by the Arabs before the ninth century. However, Arab scholars translated the Greek texts of Dioscorides and Galen, and became familiar with the medicinal properties of cannabis $[3,5]$. The Greeks and the Romans also grew cannabis to obtain fibre. Early texts on herbal medicines (De Materia Medica) were summarised by Dioscorides (40 - 90 A.D.) and by Galen (129 - 216 A.D.), who wrote of cannabis in the 2nd century A.D. in "De Alimentorum Facultatibus". 
Cannabis appeared in the 1788 New England Dispensatory, which included elements of Dioscorides herbal pharmacopoeia; therefore, cannabis was a common pain remedy in Western medicine in the 1800s [6,7], before aspirin was popularised.

In the 19th century, the interest of the therapeutic potential use of cannabis to Western medicine is primarily due to an Irish physician, William Brooke O'Shaughnessy [8]. Thus, the treatment of general pain, muscle spasms, or stomach cramps is one of the main medicinal uses of cannabis in the UK. However, their use declined in the early 20th century, due to their psychoactivity and effects on behaviour; as a result, cannabis was removed from the British Pharmacopoeia in 1932 and prohibited in 1973 by the Misuse of Drugs Regulation, which is classified in Schedule 1.

In spite of restrictions, renewed interest in the pharmacology and potential therapeutic use of natural cannabinoids was induced by the isolation and elucidation of natural cannabinoids from marihuana extract.

From the 1960s, the isolation of pure compounds from mixtures and elucidation of the structure of these compounds were possible due to the availability of novel chromatography and NMR spectrometric methods. Thus, many cannabinoids were isolated, including cannabidiol [9], $\Delta 9-\mathrm{THC}$, which was reported by Gaoni and Mechoulam in 1964 [10] (Fig. 1), and the subsequent discovery of other natural cannabinoids $[10,11]$. 
Fig. (1). Phytocannabinoids

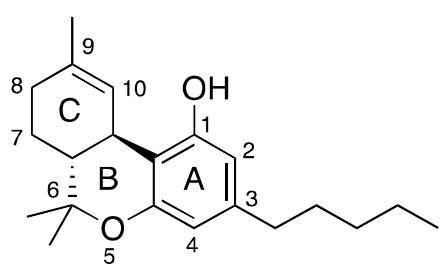

(-)- $\Delta^{9}-$ trans-THC

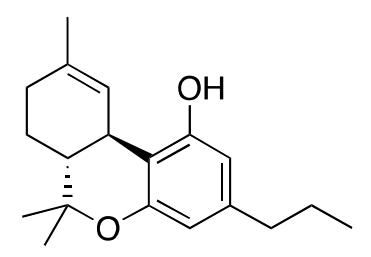

$(-)-\Delta^{9}-\mathrm{THCV}$

\section{Tetrahydrocannabivarin}

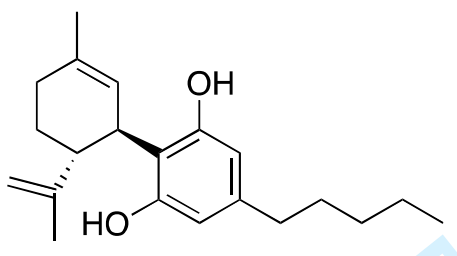

CBD

(-)-Cannabidiol

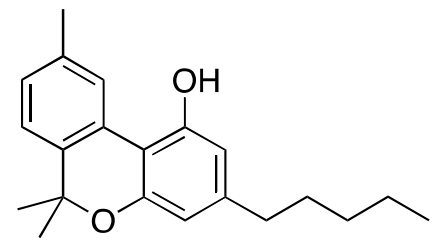

CBN

Cannabinol

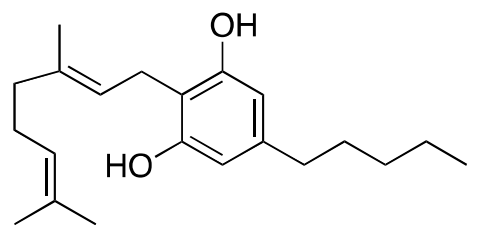

CBG

Cannabigerol<smiles>C=C(C)[C@@H]1CCC(C)=C[C@H]1c1c(O)cc(CCC)cc1O</smiles>

Cannabidivarin (CBDV)

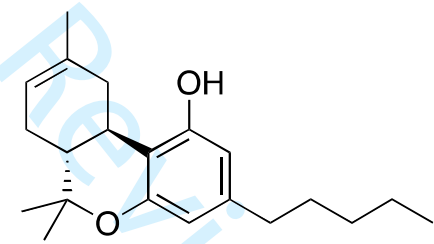

$(-)-\Delta^{8}$-trans-THC

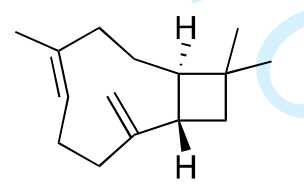

(-)- $\beta$-Caryophyllene

Thereafter, the development of synthetic cannabinoid receptor ligands, such as CP55,940 [12] (Fig. 2) in the 1980s, and the identification of specific $\triangle 9-$ THC binding sites in the human CNS [13], led to the identification of the first cannabinoid receptor. The existence of this receptor was confirmed when Howlett showed that cannabinoids decreased cAMP in neuroblastoma cell cultures [14], suggesting mediation by a Gi/o-coupled receptor [15-17].

The discovery of this cannabinoid receptor and the availability of potent cannabimimetics motivated the search for endogenous ligands capable of binding to them. Thus, the identification of the first cannabinoid receptor (CB1), cloned in 1990 [18], led to the isolation and characterisation of the first endocannabinoid two years later, the arachidonoylethanolamide (AEA), named anandamide, from the 
Sanskrit 'internal bliss' [19]. The CB2 receptor was identified and cloned in 1993 [20]. Afterwards, a family of lipid transmitters that serve as endogenous ligands for the CB1 and CB2 receptors was identified.<smiles>CCCCCCC(C)(C)c1ccc(C2CCC[C@@H](O)C2)c(O)c1</smiles>

CP 47,497<smiles>CCCCCCC(C)(C)c1cc(OC)c([C]2CC3CCC2C3CO)c(OC)c1</smiles>

HU-308<smiles>CCCCC(C)(C)c1ccc([C@@H]2C[C@H](O)CC[C@H]2CCCO)c(O)c1</smiles>

CP 55,940

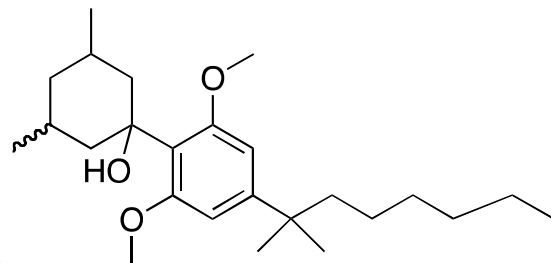

1, O-1966A

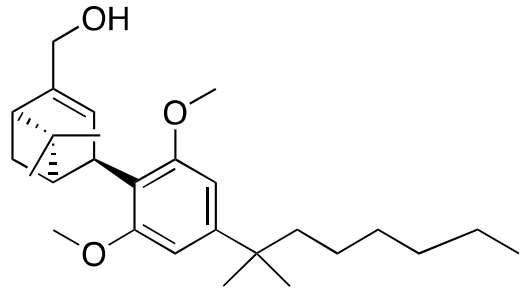

HU-433

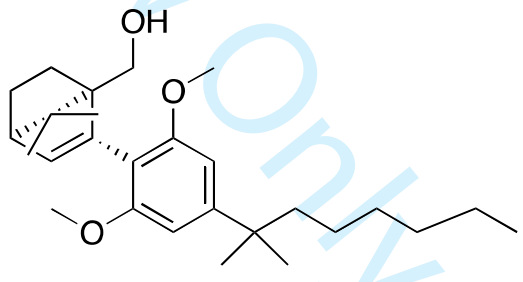

HU-910

Fig. (2). Selected CP55,950 analogs

In this context, this article will review the current knowledge of the therapeutic potential of cannabinoid receptors as targets in Alzheimer's disease and other less well-known diseases, including multiple sclerosis, bone metabolism, and Fragile X syndrome. The therapeutic applications will be addressed through the study of cannabinoid agonists acting as single drugs and multi-target drugs, highlighting the $\mathrm{CB} 2$ receptor agonist. 


\section{Endocannabinoid system}

The endocannabinoid system is a complex endogenous signalling system that comprises transmembrane endocannabinoid receptors, their endogenous ligands (the endocannabinoids), the specific uptake mechanisms and the enzymatic systems related to their biosynthesis and degradation. The endocannabinoid system (eCS, a term introduced by Di Marzo \& Fontana in 1995) [21] plays significant functions in many biological processes, in both normal and pathological conditions that affect the physiology and pathology in the central (CNS) and peripheral [22] nervous systems (for reviews: $[22,23])$.

The cannabinoid receptors belong to the family of G-protein coupled receptors (GPCRs), one of the largest and most studied superfamily of transmembrane proteins [24]. CBRs have been described in many species, including humans, monkey, pig, dog, rat and mouse, but not in insects [25]. The percentage of identity between both CB1 and CB2 receptors and between different species is very variable. Human CBRs exhibit $68 \%$ amino acid sequence identity within the transmembrane region and $44 \%$ amino acid sequence identity throughout the total protein [26].

Initially, it was described that the distribution of CB1 was predominantly in the brain, whereas CB2 was localised in peripheral cells and tissues derived from the immune system. However, along the years, it has been demonstrated by the scientific community that both receptor are widespread along the human body being involved in a great number of biological processes (Fig. 3). CB1 receptors are the most abundant $\mathrm{G}$ protein-coupled receptors in the central nervous system, expressed in both neurons and glial cells, where they regulate neurotransmitter release and act as modulators of excitatory and inhibitory neurotransmission. Regarding the distribution of the CB1 receptor in the CNS [27], this receptor has been found in the hippocampus, some olfactory regions, the caudate, putamen, accumbens nucleus, the substantia nigra pars reticulata, globus palidus, and the horizontal limb of the diagonal band $[13,28]$. Moreover, CB1 receptors are also found in peripheral tissues, such as the cardiovascular and reproductive systems, as well as the gastrointestinal tract [22,29-33]. Thus, CB1 is expressed in the heart, uterus, testis, liver and small intestine, as well as in immune cells [22] and adipose tissue [34]. CB1 receptors regulate important brain functions, including cognition and memory, emotion, motor control, feeding, and pain perception [26] playing an important role in energy balance and metabolism [35].

CB2 receptors are mainly expressed in peripheral tissue. Initially, this receptor was localised in cells of the immune system, which are responsible for the release of cytokines. These receptors were localised on immune cells such as monocytes, macrophages, B-cells, and T-cells [36-39].

In relation to the nervous system, CB2 receptors are mainly located in microglia [40], even though relatively low CB2 receptor expression has also been identified in some neurons [41]. CB2 receptors were found also in other peripheral organs, such as the muscle, liver, intestine and testis [22]. Several studies have reported that CB2 receptor expression might be induced in glial cells (reactive microglia) in response to different damaging conditions associated with local inflammation [42]. 

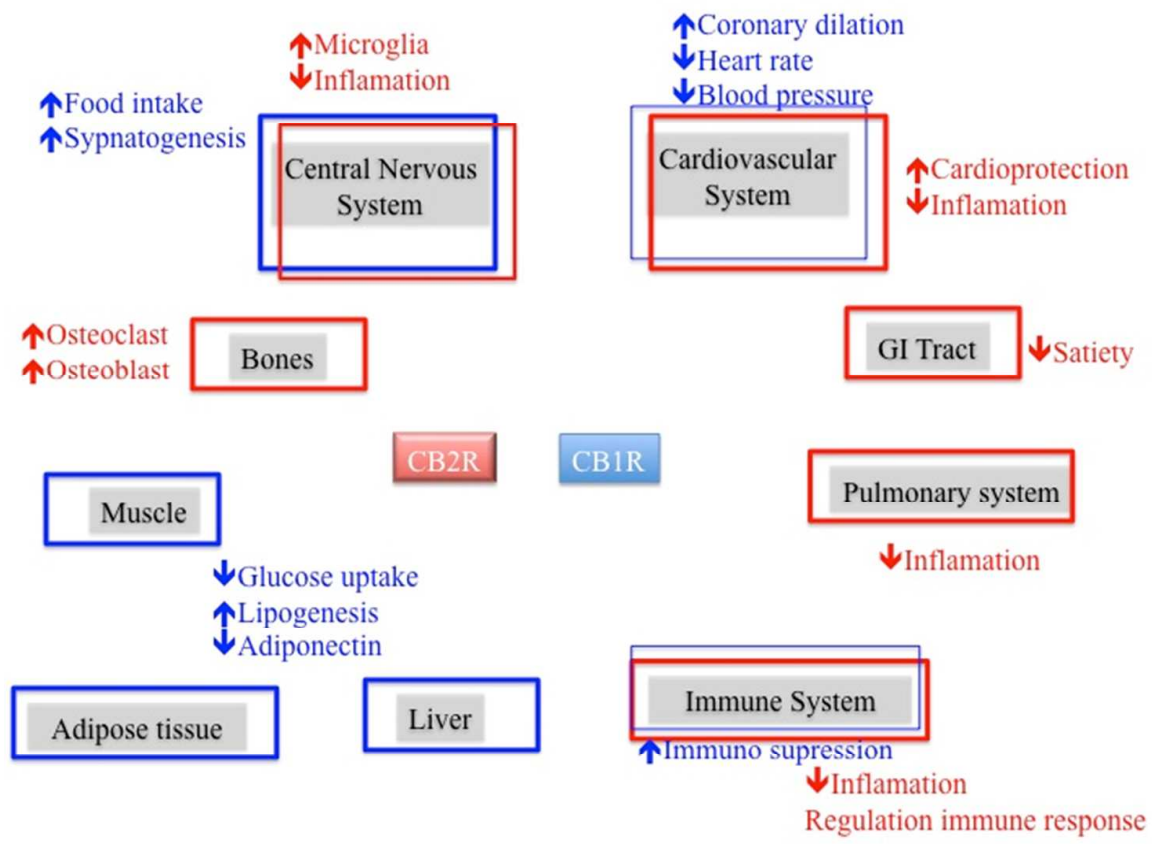

Fig. (3). Schematic representation of the functional role of $\mathrm{CB} 1$ and $\mathrm{CB} 2$ receptors

In the last decade, increasing evidence has shown that cannabinoid receptors may act as CB1-CB2 receptor heteromers in the brain [43]. In fact, the expression of CB1-CB2 receptor heteromers was determined in a variety of brain regions, such as the nucleus accumbens, pineal gland and globus pallidus [43]. The first-generation of allosteric modulators of CB1 receptors, their structure-activity relationships, signalling pathways and the allosteric binding site(s) on the $\mathrm{CB} 1$ receptor have been recently reviewed [44].

In addition, the formation of A2aR-CB1R heteromeric complexes has also been described [45, 46]. Other complexes have been found, as CB1R and 5-HT2aR form heteromers that are expressed and functionally active in specific brain regions involved in memory impairment [45].

The endocannabinoid system is a highly complex organisation where endocannabinoid molecules can interact with 7-transmembrane receptors (CB1, CB2, GPR18, GPR55 (“supposed CB3”) [47,48] and GPR119 [49]), nuclear receptor (PPAR $\alpha, \operatorname{PPAR} \beta / \delta$ and PPAR $\gamma)[50,51]$ and transmitter-gated channels (TPRV1) [52,53]. The ECS appears to interact with other neurotransmission systems, including the serotonin (5-HT3) receptor, the N-methyl-D-aspartate (NMDA) receptor and nicotinic acetylcholine receptors (nAChRs) [see reviews 54]. Furthermore, the endocannabinoid system has also an important role in the signalling of rewarding events through to the dopaminergic mesolimbic system which is the brain neurotransmitter system that is most clearly involved in this type of process [55], as well as the stimulation or inhibition of GABA release, depending on the dose and brain regions, probably via dopaminergic modulation [56].

Modulation of cannabinoid signalling by interactions with various serotonergic receptors, such as 5HT2A [57] or 5-HT4 receptors [58], has been also demonstrated. 
Recently, the role of endocannabinoid signalling in the different effects of acupuncture have been reviewed [59].

\subsection{Endocannabinoids}

Endocannabinoids are a family of lipid transmitters, which act as endogenous ligands and activate the $\mathrm{CB} 1$ and/or CB2 receptors. The brain produces at least five endogenous ligands that possess an affinity for cannabinoid receptors (Fig. 4). These endocannabinoids are amides, esters and ethers of long chain polyunsaturated fatty acids, which act as new lipid mediators. The first endogenous ligands for $\mathrm{CB}$ receptors were discovered and characterised as arachidonoylethanolamide (Anandamide, AEA) [19]. AEA binds to both $\mathrm{CB} 1$ and $\mathrm{CB} 2$ receptors [60], but its affinity for the $\mathrm{CB} 2$ receptor is approximately four-fold lower than for the CB1 receptor [61] (Table 1). Subsequently, the fatty acid ester 2-arachidonoylglycerol (2-AG) was described [62, 63]. 2-AG is a full agonist of both CB1 and $\mathrm{CB} 2$ receptors $[64,65]$. Although it exhibits a lower affinity for $\mathrm{CB} 1$ than anandamide, it is present in the brain at higher levels. Whereas AEA is a partial CB1 receptor agonist, 2-AG is considered the primary endogenous agonist for $\mathrm{CB} 1$ and $\mathrm{CB} 2$ receptors with similar affinity for both.

Table 1.

Other possible endocannabinoids have been proposed, such as a fatty acid ether, 2-arachidonylglyceryl ether (Noladin ether) [66], O-arachidonoylethanolamine (Virodhamine) [67] and Narachidonoyldopamine (NADA) [68], but their natural occurrence and roles are still unclear.

For some years, it has been reported that endocannabinoid ligands are exclusively synthesised on demand to act on cells located near their site of biosynthesis, and subsequently inactivated by the action of specific degradation enzymes. However, recent studies have shown intracellular stores of anandamide in adiposomes with higher level than in the extracellular space [69, 70].

The levels of endocannabinoid ligands are also controlled by specific enzymes as FAAH for AEA and MAGL for 2arachidonoylgycerol [71-75]. 


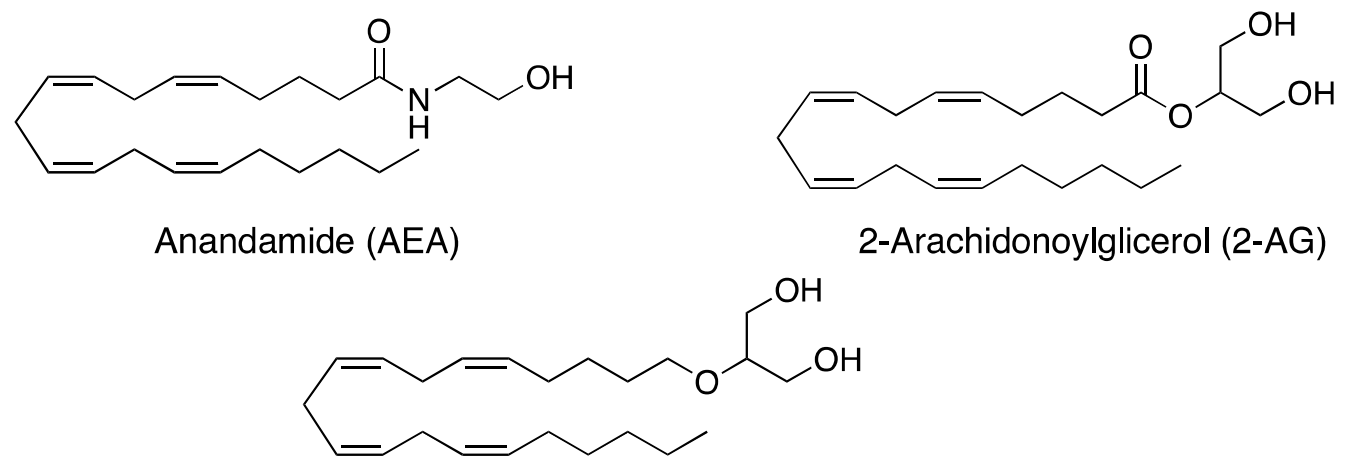

Noladin ether (2-AGE)

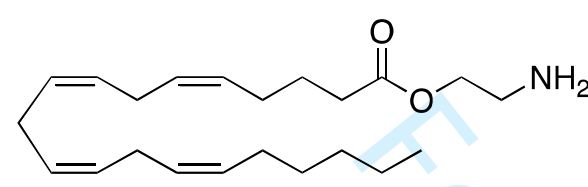

Virodhamine<smiles>CCCCCCCCCCC(=O)NCCc1ccc(O)c(O)c1</smiles>

$\mathrm{N}$-2-arachidonoyldopamine (NADA)

Fig. (4). Endocannabinoids

\subsection{Cannabinoid receptor ligands}

Taking into account the major interest in cannabinoid agonists for diseases, which are included in this report, this section will focus mainly on these ligands, with special emphasis on the properties of agonists against the $\mathrm{CB} 2$ receptor and in the analysis of the most important aspects of their activity and selectivity (For recent reviews see: [76-80]).

Cannabinoid receptor antagonists have also been reviewed elsewhere, especially those compounds of the 1,2-diarylpyrazole class, where the most representative compound is SR141716A (Rimonabant; Acomplia $\left.{ }^{\circledR}\right)$ reported in 1994 by the Sanofi group as a selective CB1 antagonist [81-84] and AM251 used as a reference derivative in pharmacological assays such as CB1-selective receptor antagonists. In addition to 1,2-diarylpyrazoles, aminoalkylindoles (AAIs) and analogue ligands appeared to be quite interesting, not only due to the selectivity of some derivatives but also due to their agonist or antagonist properties (Fig. 5). Thus, the aminoalkylindole AM630 was the first described CB2selective antagonist derived from this class of compounds [85].

In addition, novel antagonists and inverse agonists of the $\mathrm{CB} 2$ receptor have been described; these are, however, outside the scope of the current review (for reviews on antagonist and inverse agonists, see [86-91]). 
1

2

3

4

5

6

7

8

10<smiles>Cc1c(C(=O)NN2CCCCC2)nn(-c2ccc(Cl)cc2Cl)c1-c1ccc(I)cc1</smiles>

AM251<smiles>Cc1c(C(=O)NN2CCCCC2)nn(-c2ccc(Cl)cc2Cl)c1-c1ccc(Cl)cc1</smiles>

SR141716A<smiles>COc1ccc(C(=O)c2c(C)n(CCN3CCOCC3)c3cc(I)ccc23)cc1</smiles>

AM630

Fig. (5). Selected cannabinoid receptor antagonists

First generation cannabinoid receptor agonists can be classified into different groups: phytocannabinoids (Fig. 1), which include the natural products isolated from Cannabis sativa, synthetic analogues of natural cannabinoids, usually bicyclic systems lacking the pyran ring such as CP-55,940 [12] (Fig. 2), and aminoalkylindoles, with WIN55212-2 being the most representative member [61] (Fig. 6). In addition to these major groups, other chemical structures have proven cannabinoid properties and are the subject of intensive research.

In this review, synthetic cannabinoid receptor agonists have been classified into different groups from a chemical point of view as a function of the heterocyclic system. 


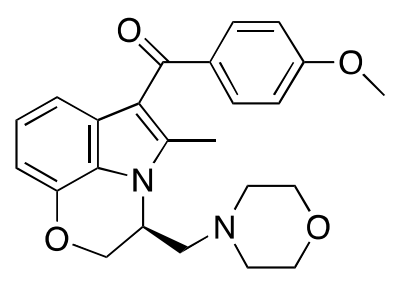<smiles>Cc1c(C(=O)c2cccc3ccccc23)c2cccc3c2n1C(CN1CCOCC1)CO3</smiles>

Pravadoline

WIN55212-2<smiles>CCCn1c(C)c(C(=O)c2cccc3ccccc23)c2ccccc21</smiles><smiles>COc1ccc2c(c1)c(CCN1CCOCC1)c(C)n2C(=O)c1cccc(Cl)c1Cl</smiles>

JWH-015

L768242<smiles>COC(=O)[C@H](Cc1ccccc1)NC(=O)c1c(C)n(CCN2CCOCC2)c2c(OC)cccc12</smiles>

21

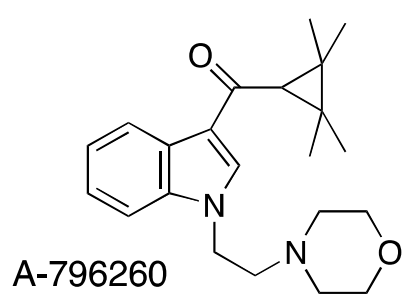

AM1241

Fig. (6). Indole derivatives

\section{Phytocannabinoids}

The plant genus Cannabis is within the plant family Cannabaceae and produces annual herbs, which are mostly dioecious and rarely monoecious. It comprises a single but variable subspecies, or varieties such as $C$. sativa, C. indica and C. ruderalis. Its taxonomy is controversial and some authors designate these varieties as distinct species [4].

The hemp plant Cannabis sativa is very complex, according to the chemical composition, as it contains over 560 phytochemical compounds [80] among 18 different chemical classes, and contain at least 104 identified phytocannabinoids [92, 93]. 


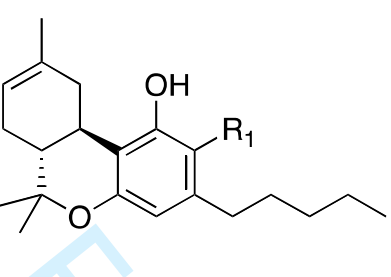

$\Delta^{8}$-trans-THC

Cannabielsoin (CBE)<smiles>[R2]c1cc2c(c(O)c1[R])-c1cc(C)ccc1C(C)(C)O2</smiles>

Cannabinol (CBN)<smiles>[R6]Oc1cc([R2])c([R])c(O)c1[C@H]1C=C(C)CC[C@H]1C([R])(C)C</smiles>

Cannabidiol (CBD)

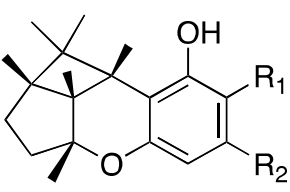

Cannabicyclol (CBL)<smiles>[R2]c1cc(O)c2c(c1[R])O[C@H]1[C@@H](O)CC[C@H](C(C)(C)C)[C@H]21</smiles>

$\mathrm{HO}$,<smiles>[R3]CC1(C)C=Cc2c(cc([R6])c([R])c2C)O1</smiles>

Cannabichromene (CBC)<smiles>[R]Oc1cc([R2])c([R7])c(O)c1CC=C([R])[R]</smiles>

Cannabigerol (CBG)

Fig (7). Structures of general types of Cannabis sativa L.

The phytocannabinoids are tricyclic terpenoid derivatives bearing a benzopyran moiety that include the natural product $\triangle 9-\mathrm{THC}$ (THC) [10] and other pharmacologically active constituents of the plant Cannabis Sativa, as well as analogue tricyclics lacking the pyran ring of THC (Fig. 1 and Fig. 2). THC, the main psychotropic constituent of cannabis, is a $\mathrm{CB} 1$ and $\mathrm{CB} 2$ receptor partial agonist. Cannabinol binds with higher affinity in the $\mathrm{nM}$ range to both receptors, showing a modest selectivity [94], whereas the $\triangle 9$-THCV behaves as a potent CB2 receptor partial agonist [95]. In this regard, the most therapeutically attractive phytocannabinoids include cannabidiol (CBD) [96-98] [7], cannabigerol (CBG), $\Delta$ 9-tetrahydrocannabivarin ( $\triangle 9$-THCV) and cannabidivarin (CBDV) (Fig. 1). More recently, the (-)- $\beta$-caryophyllene [99], a natural bicyclic sesquiterpene of Cannabis sativa, has been examined in depth.

\section{Synthetic analogues of natural cannabinoids}

In 1982, a derivative of 3-phenylcyclohexanol (CP-47,497) was described as a cannabimimetic agent, with 3 to 28-times greater potency than THC [100] (Fig. 2). Subsequently, other cannabimimetics were developed by Pfizer based upon the dibenzopyran structure of THC, which includes the wellknown ligand CP-55,940 [101]. This compound was found to be more potent than THC, is considered the prototypical example of this class and is extensively used for the evaluation of potential cannabinoid ligands in binding assays $[13,102]$. A high number of tricyclic analogues of $\triangle 9$-THC and 
analogues of CP-55,940, where the oxygen-containing pyran ring of THC has been removed, were synthesised and studied by different groups (Fig. 2).

Thus, a great number of tricyclic compounds with cannabinoid properties has been described, being Nabilone [103] and HU-210 [104, 105] the most representatives (Fig. 8). This last compound, bearing a hydroxymethyl group at C-9, was synthesised by Mechoulam et al. and is one of the most potent cannabinoid receptor agonists [106] (Table 1). Subsequently, some tricyclic compounds have been reported, along with structural analogues of $\Delta 9$-THC and $\Delta 8$-THC (Fig. 1, Table 1) and CP55,940 analogues (Fig. 2), which have shown selectivity to the CB2 receptor. Based on the similar effect (in vitro and in vivo) that $\triangle 8$-THC derivatives show in relation to $\triangle 9$-THC and taking into account that they are synthetically easier to prepare due to the increased stability of the $\Delta 8$-double bond, several analogues of the tricyclic $\triangle 8$-THC have been synthesised and studied, allowing a broad spectrum of compounds with cannabinoid properties that show selectivity for the CB2 receptor to be obtained. It is worth mentioning that compounds JWH-133 [107, 108] (Fig. 8) and the peripheral CB2 receptor agonist HU-308 [109] (Fig. 2) are the most representative members of this family, showing very high affinity for the CB2 receptor and low affinity for the CB1 receptor (Table 1). The tricyclic compound JWH-133 has been characterised as a full agonist in a GTP $\gamma$ S-binding assay at the human CB2 receptor, and HU-308 has been also described as a selective full agonist in human CB2 cyclic GMP assays.

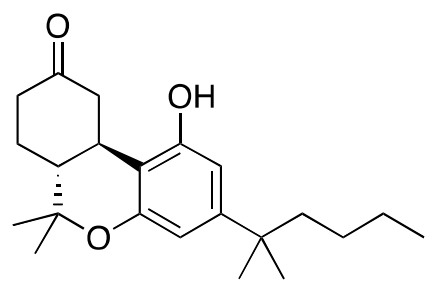

Nabilone

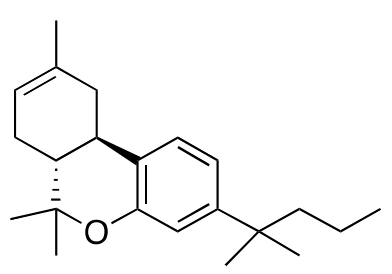

$\mathrm{JWH}-133$

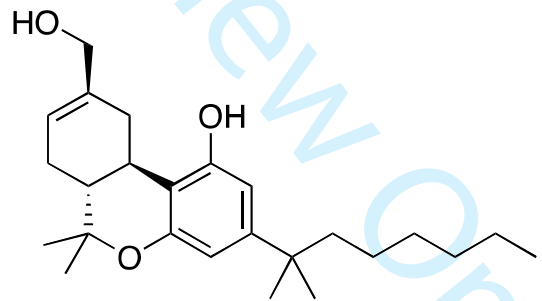

HU-210

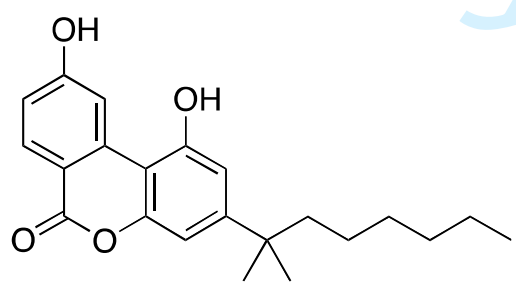

AM 1714

Fig. (8). Synthetic analogs of THC

Subsequently, new tricyclic derivatives of benzo[c]chromen-6-one have been published where the importance of lactone functionality in the observed CB2 selectivity is highlighted. Optimal receptor subtype selectivity of 490 -fold and subnanomolar affinity for the CB2 receptor is exhibited by the 9- 
hydroxyl analogue, AM1714 (Fig. 8). In functional assays, this compound behaves as an agonist, with activities comparable to WIN55212-2 and with analgesic activity [110].

Regarding CP-55,940 analogues (Fig. 2), some derivatives of resorcinol dimethyl ether have been reported. Among them, it is worth mentioning compound 1, O-1966 (Fig. 6, Table 1) since it has a selectivity of 220-fold for the CB2 receptor and very low affinity for the CB1 receptor [111].

Other groups have described new biaryl cannabinoids, where the phenol group has been replaced by a methyl morpholino acetate group, leading to compound 2 (Fig. 2), a 500-fold selective CB2 receptor agonist [112].

More recently, a structurally similar compound HU-910 (95, Fig. 5) has been reported as a potent CB2 agonist, which may exert protective effects in diseases related to inflammation and tissue injury [113]. The enantiomer of HU-308, called HU-433 (Fig. 2, Table 1), shows higher potency than HU-308, although it has a lower affinity [114].

\section{Five-member heterocyclic scaffold}

Pyrazole Derivatives. Regarding heterocyclic derivatives of five atoms, a lot of compounds have been reported with cannabinoid properties with high selectivity for the CB2 receptor (Table 1, Fig. 9). Thus, a series of derivatives obtained from the modification of heterocyclic system that include imines of oxazole, isothiazole and isoxazole have led to pyrazol-5-ylidene benzamide 3 (CBS0550), which exhibited high affinity and selectivity for the CB2 receptor and a greater aqueous solubility [115]. The Merck Research Laboratory has published different derivatives based on a 2,4-diaryl- $1 H$-imidazole scaffold. Compound $\mathbf{4}$ behaves as a potent CB2 full agonist with improved pharmacokinetic properties [116].

Isoxazole Derivatives. Moreover, a series of derivatives that include the isoxazole ring has been described. The substituents on the heterocycle system define the activity on CB2 receptor or on FAAH enzyme. SAR studies of isoxazole-3-carboxamide derivatives have shown that the presence and position of the alkoxy chain influence the biological activity and the $K_{\mathrm{i}}$ affinity (Table 1, Fig. 9). Thus, the adamatylcarboxamide 5 (ALIAE809) and cycloheptyl carboxamide $\mathbf{6}$ have shown in vivo anti-inflammatory activities in a colitis mouse mode [117].

1,3-Thiazole Derivatives. Taisho Pharmaceuticals has previously published different thiadiazol-2ylidene derivatives [118]. Thiazole 7 (Table 1, Fig. 9) with the cyclopropylmethyl group at the 3position and the presence of a bulky lipophilic group like tert-butyl at the 5-position exhibited higher CB2 affinities with a selectivity of 270 and excellent pharmacokinetics in rats [119].

1,2,4-Oxadiazole Derivatives. In order to optimise the pharmacokinetic properties of the 2-pyridone 8 (S-777469) (Fig. 10), a lot of derivatives of oxadiazole have been synthesised and SAR studies have been performed. The results led to the preparation of a potent and selective agonist of the CB2 receptor, the 5-propylamine oxadiazol 9 with excellent pharmacokinetic properties [120].

Structural modifications of the substituent at 5-position of 1,2,4-oxadiazole led to the oxadiazole $\mathbf{1 0}$ (Table 1, Fig. 9) as a conformationally constrained molecule by the replacement of a propylamine 
group of 9 by 4-piperidinyl, which improved the stability with a lower potency and greater selectivity [121].

Bicycles of Pyrazole Derivatives. Regarding condensed bicycles of pyrazole, Arena Pharmaceuticals has described cyclopenta[c]pyrazole-3-carboxamide derivatives. Through the introduction of a variety of alkyl and aryl substituents, $(5 R, 6 R)$-tetrahydrocyclopenta[c]pyrazole-3-carboxamide derivative $\mathbf{1 1}$ (Table 1, Fig. 9) was obtained. This derivative showed good activity and selectivity $(>8100)$ for CB2 receptor. In addition, this compound exhibited favourable ADME properties and was efficacious at reversing inflammatory pain after oral administration in the rat [122].<smiles>Cn1c(C(C)(C)C)c/c(=N\C(=O)c2cccc(C(F)(F)F)c2F)n1CC1CC1</smiles>

3 (CBS0550)

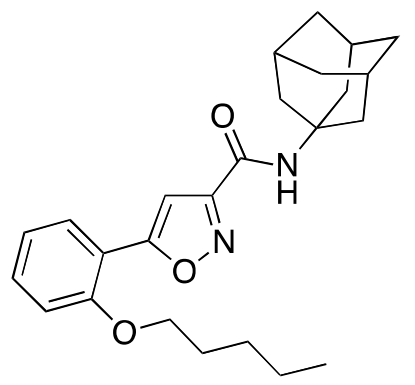

5<smiles>CC(C)(C)c1cn(CC2CC2)c(=NC(=O)c2cccc(C(F)(F)F)c2)s1</smiles>

7<smiles>Fc1ccc(-c2noc(C3CCN(c4cnc5ccccc5c4)CC3)n2)c(Cl)c1</smiles>

10<smiles>FC1(F)CCN(Cc2cccc(-c3cnc(-c4cccc(C(F)(F)F)c4)[nH]3)c2)CC1</smiles>

4<smiles>CCCCCOc1ccccc1-c1cc(C(=O)NC2CCCCCC2)no1</smiles><smiles>Fc1ccc(-c2noc(CCCNc3cnc4cc(Cl)ccc4c3)n2)c(Cl)c1</smiles><smiles>C[C@H]1Cc2c(C(=O)NC(C)(C)CO)nn(-c3ccc(F)cc3F)c2[C@@H]1C</smiles>

Fig. (9). Pyrazole, imidazole, oxazole, thiazole and oxadiazole derivatives

\section{Six-member heterocyclic scaffold}


Pyridine Derivatives. A different series of six-member heterocycles has been reported with cannabinoid properties with high selectivity for the CB2 receptor (Fig. 10 and 11).

The replacement with a pyridine ring (Table 1, Fig. 10) of the central pyrimidine core of compound GW842166X (Table 1, Fig. 11) [123, 124] used as a model led to the pyridine-3-carboxamide CB2 agonist 12 (Table 1, Fig. 10), which demonstrated efficacy in an in vivo model of inflammatory pain [125].<smiles>O=C(NCC1CCOCC1)c1cnc(Nc2ccc(Cl)cc2Cl)cc1C1CC1</smiles>

12<smiles>O=C1CN(Cc2ccc(-c3ccc(F)c(CN4CCS(=O)(=O)CC4)n3)cc2)C(=O)N1C1CC1</smiles>

14 (LEl-101)<smiles>Clc1ccc(Nc2ccc(CN3CCO[C@H](c4ccccc4)C3)cn2)c(Cl)c1</smiles>

13

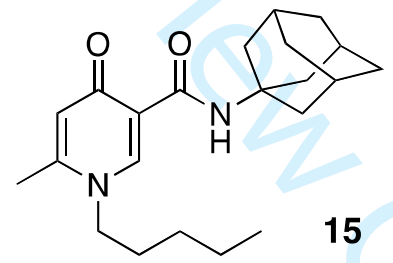

8 (S-777469)

Fig. (10). Pyridine derivatives

Boehringer Ingelheim also discovered a series of 2-aminopyridines bearing a chiral morpholine ring. Compound 13, where the carboxamide group is replaced by a methylamine group, was reported as a potent and selective CB2 receptor agonist and showed efficacy comparable to prednisolone in a mouse model of inflammation [126].

An orally available and peripherally restricted selective cannabinoid CB2 receptor agonist 14, LEI-101 (Table 1, Fig. 10), which prevents cisplatin-induced nephrotoxicity, has been described. This compound showed therapeutic potential in diseases that are associated with inflammation and/or oxidative stress, including kidney disease [127]. Other CB2 ligands based on the 3-carbamoyl-2pyridone derivatives have been reported by changing the size of side chain at the 1-, 5- and 6positions. The structure-activity relationship around this series led to the 2-pyridone derivative 8 (S777469), as a selective CB2 receptor agonist [128].

Finally, another series of 3-carbamoyl-4-pyridones, as exemplified by the adamantyl-1,4dihydropyridine-3-carboxamide 15 (Figure 9, Table 1), has also been described as potent and selective 
CB2 receptor agonists [129].

Pyrimidine Derivatives. Another interesting ligand derivative of 5-pyrimidinecarboxamide, GW842166X, has been described by GlaxoSmithKline as a selective CB2 receptor agonist. The pyrimidine-5-carboxamide GW-842166X (Table 1, Fig. 11) is the most interesting compound for the treatment of inflammatory pain [123, 124].<smiles>O=C(NCC1CCOCC1)c1cnc(Nc2ccc(Cl)cc2Cl)nc1C(F)(F)F</smiles><smiles>Clc1cccc(-c2ccc(N3CCOCC3)nn2)c1Cl</smiles><smiles>C[C@H]1CC[C@@H](C)N1c1ccc(-c2cncc3ccccc23)nn1</smiles><smiles>CC(C)c1cc(N2CCOCC2)nnc1C(=O)NC12CC3CC(CC(C3)C1)C2</smiles><smiles>CSC(=S)N1CC(C)(C)CSC1Nc1ccccc1C(C)C</smiles>

19

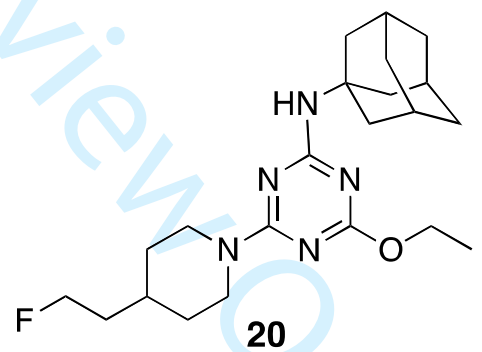

Fig. (11). Pyrimidine, pyridazine, thiazine and triazine derivatives

Pyridazine Derivatives. A series of 2-Amino-5-arylpyridazine-3-carboxamides had been identified from high-throughput screening studies as CB2 agonists. Substitution of the pyridine ring [130] with a pyridazine led to the discovery of a number of analogues with metabolic stability (compound $\mathbf{1 6}$ as representative example). The introduction of the cis-2,5-dimethylpyrrolidine group in pyridazine ring (compound 17) (Table 1, Fig. 11) led to an increase in CB2 activity [131].

The design of a series of CB2-selective agonist derivatives of pyridazine-3-carboxamides has been performed using GW842166x as a model. Several derivatives obtained exhibited enhanced potency and high selectivity at the CB2 receptor over the CB1 receptor. Specifically, $N$ adamantanylpyridazine-3-carboxamide 18 (Table 1, Fig.11) showed the highest CB2 agonist activity and remarkable CB2 selectivity (Selectivity Index > 2700) [132].

1,3-Thiazines Derivatives. A series of 1,3-thiazines has been synthesised with the objective of optimising cannabinoid properties. The most potent compound, 2-phenylimino-1,3-thiazine 19 (Fig. 
11), displays $k i$ values of $>5000$ and $9 \mathrm{nM}$ for the CB1 and CB2 receptors, respectively (Table 1). Functional assays indicate that this thiazine behaves as a cannabinoid receptor agonist with analgesic activity due to activation of the CB2 receptor [133, 134].

1,3,5-Triazine Derivatives. Finally, a series of 2,4,6-Trisubstituted 1,3,5-triazines was identified as a potent CB2 agonist by 3D ligand-based virtual screening [135]. Subsequently, an additional series with enhanced water solubility was described. The most interesting compound was the adamantanylamino-1,3,5-triazine 21 (Fig. 11, Table 1), which induced decreased cell viability in prostate and leukaemia cell lines and diminished the proliferation of C8161 melanoma cells [136].

\section{Bicyclic [6+5] heterocyclic core}

Indole Derivatives. In relation to first generation cannabinoids, other classes of cannabimimetics include the aminoalkyldindoles developed by Sterling Winthrop as potential non-steroidal antiinflammatory agents. In 1991, the unexpected inhibition of the electrically simulated mouse vas deferens by Pravadoline was published [137]. Other indole derivatives were developed with increased cannabinoid potency, like WIN55212-2, which it is a potent CB1 and CB2 receptor agonist $[61,138]$. A great number of indole derivatives have been synthesised by structural modifications of all positions of the ring [139-142].

Several groups have worked in the development of selective ligands for the CB2 receptor. These efforts have allowed the description of two different series of cannabimimetic indoles, with the most representative compounds being 2-methyl-1-propyl-3-(1-naphthoyl)indole (JWH-015) [143] and 1(2,3-dichlorobenzoyl)-2-methyl-3-(2-[1-morpholino]ethyl)-5-methoxyindole (L768242) [144]. These derivatives have high affinity for the CB2 receptor and low affinity for the CB1 receptor (Fig. 7, Table 1). Functionally, L768242 displays partial agonist activity in human CB2 receptor-mediated inhibition of forskolin-stimulated cAMP release assays [145]. Makriyannis' group also discovered another interesting cannabimimetic aminoalkylindole, AM1241, which has been found to exhibit high affinity for human, rat and mouse CB2 receptors [146]. The efficacy of AM1241 in models of inflammatory [147] and neuropathic pain [148] has been shown to be mediated by the CB2 receptor, since the effects are blocked by $\mathrm{CB} 2$ receptor antagonists but not by $\mathrm{CB} 1$ antagonists.

Other series of indole derivatives have been published by Bristol-Myers Squibb, with the most interesting being the indole-3-carboxamide 21 (Table 1, Fig. 6). This derivative has been described as a very selective $\mathrm{CB} 2$ agonist that inhibits pro-inflammatory responses in a murine model of acute inflammation [149].

Moreover, a new series of indolylketones has been described by Abbot $[150,151]$. Thus, an interesting new ligand derivative of indole, A-796260 (Fig. 6, Table 1) has been described as a potent and selective CB2 agonist with anti-hyperalgesic and anti-allodynic properties in models of chronic inflammatory and neuropathic pain [150].

Benzo[d]imidazole Derivatives. New series of benzo[d]imidazole CB2-receptor agonists have been described (Fig. 12). The group at the 2-position determines the level of agonism, ranging from inverse 
agonism to partial agonism or full agonism [152]. The most promising derivative is the 5sulphonylbenzo $[d]$ imidazole 22 (Fig. 12, Table 1), that showed activity as potent CB2 receptor agonist and excellent selectivity ( $>4000$-fold) over the CB1 receptor [152].<smiles>CCOc1cc(S(=O)(=O)c2ccc3c(c2)nc(C(C)(C)C)n3CC2CCOCC2)ccn1</smiles>

22
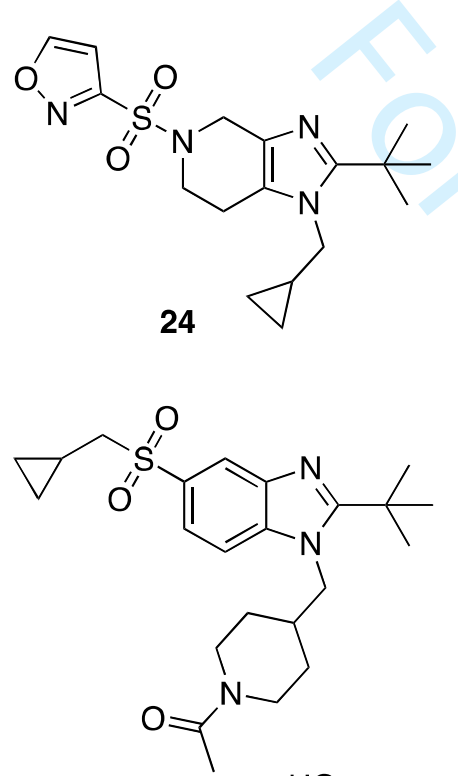<smiles>CCOc1ccc(Cc2nc3cc(C(=O)N(CC)CC)ccc3n2CC2CC2)cc1</smiles>

23<smiles>CCS(=O)(=O)c1ccc2c(c1)nc(C(C)(C)C)n2CC1CCCO1</smiles>

25

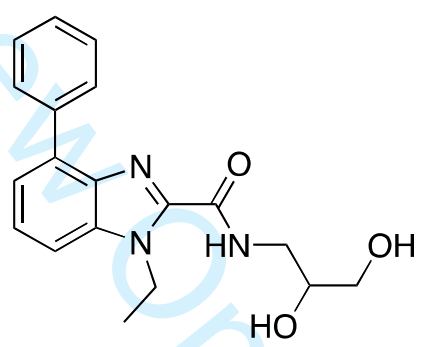

27

28 (RQ-00202730)

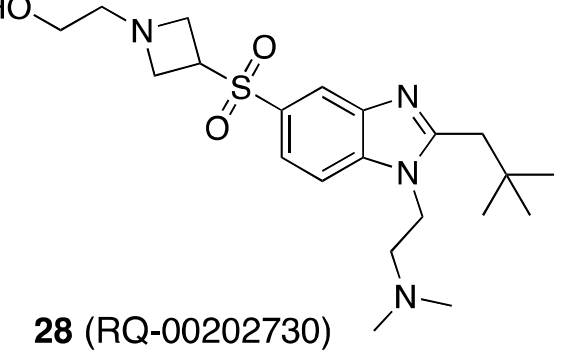

Fig. (12). Benzo $[d]$ imidazole derivatives

Other CB2 agonists based on benzo[d]imidazole template have been reported by AstraZeneca from HTS studies. SAR studies around benzo[ $[d]$ imidazole derivatives modifying the $\mathrm{N}-1$ position with alkyl and aromatic groups led to the 1 -cyclopropylmethyl derivative $\mathbf{2 3}$ with optimal potency and selectivity [153].

Further studies by Pfizer on the benzimidazole core led to the preparation of a large number of sulphonyl derivatives. The introduction of a neopentyl group at the 2 position together with a 
sulphonyl group at the 5 position led to one of the best compounds of these series, the 5 -sulphonyl tetrahydorbenzo[ $[d$ imidazole 24, (Table 1, Fig. 12), which behaves as a selective and potent full agonist of the CB2 receptor [154].

Other studies of the optimisation of the benzo[ $[d]$ imidazole substituents led to the discovery of the fully CNS penetrant CB2 agonist 5-ethylsulphonylbenzo[d]imidazole 25 (Table 1, Fig. 12) with reduced human hERG activity [155].

Moreover, other series of sulphonylbenzo $[d]$ imidazole $\mathrm{CB} 2$ receptor agonists have been developed by Janssen Pharmaceuticals. Thus, the 5-sulphonylbenzo $[d]$ imidazole cannabinoid agonists 26 (Table 1, Fig. 12), showed an excellent binding affinity and selectivity for $\mathrm{CB} 2$. In addition, this compound displayed good, sustained activity in a chronic model of neuropathic pain, which delayed the onset of clinical symptoms in an experimental model for multiple sclerosis [156].

Other new series of benzo[ $[d]$ imidazole-2-carboxamide derivatives have been described. The most potent 2-carboxamide 27 (Fig. 12) in this series was obtained by the introduction of an aliphatic amide bearing two hydroxyl groups [157].

Regarding indazole series, it is worth highlighting compound 28 (RQ-00202730, Fig. 12), which bears an aazetidin-3-ylsulphonyl group at position 5 of the benzo[d]imidazole ring. RQ-00202730 demonstrated the best overall profile in terms of potency and selectivity of this series over the CB1 receptor, showing a dose-dependent analgesic effect on TNBS-induced visceral hypersensitivity in rats by oral administration [158].

Pyrazolo[3,4-b]pyridine Derivatives. A series of heteroaryl-4-oxopyridine and 7-oxopyrimidine derivatives has been described [159]. An interesting condensed heterocycle was the pyrazole ring exemplified by the $N$-adamantanyl-4-oxopyrazolo[3,4- $b$ ]pyridine-5-carboxamide 29 (Table 1, Fig. 13) that acts as a partial agonist.

Imidazo[1,5-a]pyridine Derivatives. Other series of condensed pyridine derivatives relate to imidazo[1,5-a]pyridines, which have been described by analogy with indole ligands as CB2 agonists. The 3-morpholinoimidazo[1,5-a]pyridine-1-carboxamides 30 and 31 (Table 1, Fig. 13) were the most interesting derivatives, since they are selective for CB2 and show analgesic effects [160].

Purine Derivatives. Lilly Research Laboratories have described a series of purine derivatives as CB2 receptor agonists by analogy with the thieno[2,3- $d]$ pyrimidine scaffold. The selectivity for CB2 and the metabolic profile were further optimised by the modification of a substituent at the 9 position of the purine ring. The $(R)$-4-methylpiperazin-1-ylpurine 32 and the 9-tetrahydropyranpurine 33 (Fig. 13, Table 1) showed potent oral activity in a preclinical model of joint pain $[161,162$.

Benzofurane Derivatives. Finally, it is worth highlighting another CB2 receptor agonist, 34 (MDA7, 1-((3-benzyl-3-methyl-2,3-dihydro-1-benzofuran-6-yl)carbonyl)piperidine) [163] (Table 1, Fig. 13). This compound was active in a model of neuropathic pain and has been studied as a novel therapeutic target in the treatment of $\mathrm{AD}$, as will be discussed later. 
<smiles>CCCCCn1cc(C(=O)NC23CC4CC(CC(C4)C2)C3)c(=O)c2cnn(C)c21</smiles>

29<smiles>O=C(c1cccc(Cl)c1Cl)c1nc(CN2CCOCC2)c2ccccn12</smiles>

31<smiles>Cc1nc(N2CCN(C)CC2)c2nc(-c3ccccc3Cl)n(C3CCOCC3)c2n1</smiles><smiles>O=C(NC1(CO)CCCC1)c1nc(N2CCOCC2)n2ccccc12</smiles><smiles>Cc1nc(N2CCN(C)CC2)c2nc(-c3ccccc3Cl)n(CCS(C)(=O)=O)c2n1</smiles>

32

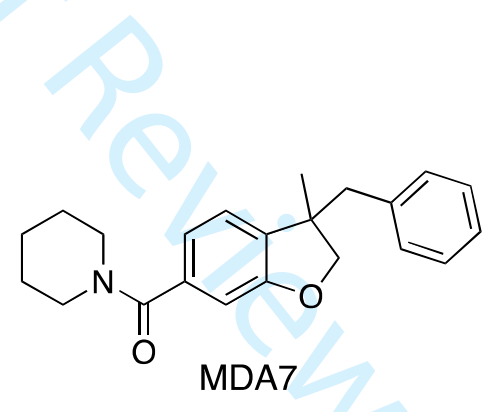

Fig. (13). Pyrazolo[3,4-b]pyridine, imidazo[1,5- $a]$ pyridine, purine and benzofurane derivatives

\section{Bicyclo [6+6] scaffold}

Quinoline Derivatives. One of the earliest series of synthetic CB2 receptor agonists included bicyclo [6+6] scaffolds such as 4-oxoquinoline. Thus, it was reported that compound $\mathbf{3 5}$ shows a high affinity for the CB2 receptor with a selectivity that is $>300$-fold (Table 1, Fig. 14). This compound behaves as an agonist according to [35S]GTPg binding assays and functional studies [164]. Besides, other series of 4-oxo-1,4-dihydroquinoline-3-carboxamides have been reported. The most interesting derivative, 36, is reported as a CB2 agonist with high selectivity for the CB2 receptor [165] (Table 1, Fig. 14).

The substituents at different positions of the heterocyclic system were studied; one of the most potent CB2 agonists of these series was 37 (Fig. 14, Table 1), which demonstrated analgesic effects in a mouse formalin test of acute peripheral and inflammatory pain [166].

Other published derivatives related to the decahydroquinoline CB2 agonists were reported by the Merck Research Laboratories. Optimisation of the amide substituent led to the selective CB2 agonist 38 (Table 1, Fig. 14), which displayed a dose-dependent analgesic effect [167]. 
1,8-Naphthyridine Derivatives. The CB2 receptor agonists also include 4-oxo-1,8-naphthyridine-3carboxamide derivatives [168] [165]. Different series of 1,8-naphthyridin-2(1H)-on-3-carboxamide analogues were described as CB2 receptor agonists. Thus, the naphthyridine 39 [164] (CB13, Fig. 14) induces apoptosis in colon cancer cells [169].

In another series of cannabinoid receptor agonists, the 2-oxo-1,8-naphthyridine-3-carboxamide 40 (Table 1, Fig. 14) exerted a CB2-mediated inhibitory action on immunological human basophil activation [170].

Finally, the structure-activity relationships for 4-oxo-1,8-naphthyridine-3-carboxamides were described with different substituents in position N-1 or C-6. The substituents in C-6 determined the functionality as agonist or antagonist/inverse agonist. An example of cannabinoid receptor agonist is derivative 41 (Table 1, Fig. 14) which showed good results for both CB2 affinity and selectivity [171]. 
<smiles>O=C(Cc1cn(CN2CCOCC2)c2ccccc2c1=O)NC1CCCCC1</smiles>

35<smiles>CCCCCn1cc(C(=O)NC23CC4CC(CC(C4)C2)C3)c(=O)c2cc(C(C)C)ccc21</smiles>

37<smiles>CCCCCn1cc(C(=O)NC2CC3CCC2C3)c(=O)c2ccccc21</smiles>

36<smiles>Cc1ccc(C(=O)N2C=C[C@H](O)[C@]3(CCCC[C@@H]3c3ccccc3)C2)cn1</smiles>

38<smiles>CC1CCC(NC(=O)c2cc3cccnc3n(Cc3ccccc3)c2=O)CC1</smiles>

40

39 (CB13)<smiles>CC1CCC(NC(=O)c2cn(CCN3CCOCC3)c3ncc(CCCCF)cc3c2=O)CC1</smiles>

Fig. (14). Quinoline and naphthyridine derivatives

\section{Tricyclic Heterocycle scaffold}

Pyrido[4,3-b]indole Derivatives. The $\gamma$-carboline series was identified by a scaffold from the bicyclic benzimidazole core as mixed CB and CB2 agonists [172]. This new structural class of cannabinoid agonists showed good physicochemical properties and low CNS penetration. The ethylsulphonyl derivative 42 (Table 1, Fig. 15) behaves as an agonist (Table 1) exhibiting significant antihyperalgesia in a rat inflammatory pain model with low levels of CNS penetration [172]. 
1

2

3

4

5

6

7

8

Pyrazolo[4,3-clquinoline Derivatives. Very recently, the $2 H$-pyrazolo[4,3-c]quinolin-3(5H)-one scaffold was developed as constrained analogues of the 4-oxo-1,4-dihydroquinoline-3-carboxamide series with improved affinity and selectivity for the CB2 receptor. The focus of this series was the adamantanylmethyl-3-oxo-pyrazolo[4,3-c]quinoline $\mathbf{4 3}$ (Table 1, Fig. 15), which was found to protect mice against experimental colitis after oral administration [173].

Benzo[b]quinolizine Derivatives. Other tricyclic cannabinoid receptor agonist derivatives of quinolizin-6-one were described. Sch35966 44 (8,10-bis[(2,2-dimethyl-1-oxopropyl)oxy]-11-methyl1,2,3,4-tetrahydro-6H-benzo[b]quinolizin-6-one) displays high affinity for the CB2 receptor and good selectivity for CB2 receptor (Table 1, Fig. 15) [174].

Oxazino[2,3,4-ij]quinoline Derivatives. A tricyclic system based on the 4-oxoquinoline-3carboxamide (Fig.14) and the indole scaffolds (Fig. 6) is the oxazino[2,3,4-ij]quinoline scaffold. Compound 45 (MT178) (Fig. 15, Table 1), in which a pyrrolidine moiety was introduced in position 10, showed high affinity and selectivity at the CB2 receptor (Table 1) [175]. MT178 produced analgesia in inflammatory and chronic pain models via CB2 receptors [176].<smiles>CCS(=O)(=O)N1C2=C(CN(C3CCOCC3)CC2)C2C=C(C(=O)N3CCC(C)CC3)C=CC21</smiles>

42<smiles>CC1c2c(OC(=O)C(C)(C)C)cc(OC(=O)C(C)(C)C)cc2C(=O)N2CCCCC12</smiles>

44 (Sch35966)

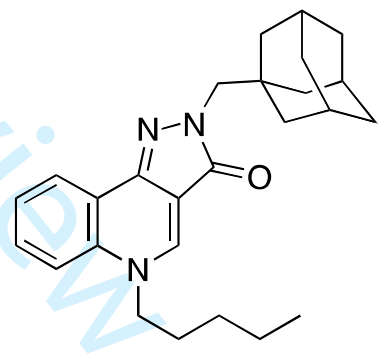

43<smiles>CCC1COc2c(N3CCCC3)ccc3c(=O)c(C(=O)NC45CC6CC(CC(C6)C4)C5)cn1c23</smiles>

45

Fig. (15). Derivatives of tricyclic heterocycles

\section{Other synthetic cannabinoid structures}

Lastly, other different structures with high selectivity to CB2 receptors, such as sulphone [177], arylsulphonamide, [178] amidosulphone [179], 1,4-Diazepane and proline [180,181] derivatives should be mentioned, which behave as cannabinoid receptor agonists (Fig. 14). 


\section{Multi-target Cannabinoid Receptor Agonists}

In the past, drug discovery was based on the premise that a promising drug candidate should exhibit high potency and high selectivity of action. However, the complexity of human diseases often requires multiple approaches for effective treatment, as it is well known for the treatment of different types of cancer. Nowadays, there is increasing recognition of the limitations of the premise that high selectivity and high potency are the most desirable properties for discovery of new therapeutic agent. Thus, during the last decade, a new paradigm, called multi-target directed ligand (MTDL), multiple ligands (DMLs) or multiple ligand strategy (MLS) has been developed as an innovative approach dedicated for complex diseases [182-184].

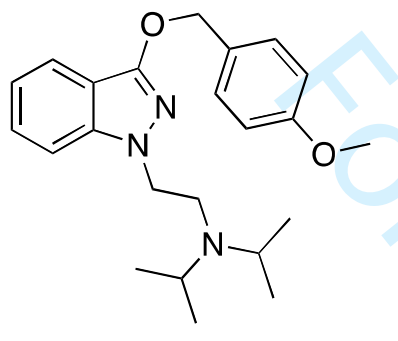

46 (PGN33)<smiles>COc1ccc(CC(=O)n2nc(OCCCN3CCCCC3)c3ccccc32)cc1</smiles><smiles>CCOC(=O)c1ccc2c(c1)nc(Cc1ccc(OCC)cc1)n2CCC(C)C</smiles><smiles>Nc1ccc2c(c1)c(OCc1ccc3ccccc3c1)nn2CCN1CCCCC1</smiles>

47 (PGN34)<smiles>O=C(c1cccc(Cl)c1Cl)n1nc(OCCN2CCCC2)c2ccccc21</smiles>

49 (NP43)

Fig. (16). Multitarget cannabinoid receptor agonists

In this respect, a novel series of indazole ether derivatives have been described as cannabinoid receptor agonists with simultaneous affinity towards other receptors (Fig. 16). Thus, using docking studies, a set of indazol ethers that behave as CB2 cannabinoid agonists and BuChE inhibitors have been designed. In particular, compounds 46 (PGN33) and 47 (PGN34) have emerged as promising 
candidates as novel $\mathrm{CB} 2$ receptor agonists that simultaneously inhibit $\mathrm{BuChE}$ by a non-competitive or mixed mechanism, respectively. On the other hand, in addition, both molecules show antioxidant properties [185].

Subsequently, other series of indazole derivatives have been described as multi-target ligands (Fig. 16). Thus, some indazolylketone derivatives as 48 (PGN43) and 49 (PGN137) have been describe that behave as $\mathrm{CB} 2$ cannabinoid agonists and simultaneously shown BuChE and/or BACE-1 inhibition [186]. Moreover, new derivatives of aminobenzimidazole agonists as a second-generation of compound 50 have been designed as cannabinoid agonists with the inhibitory activity of $\mathrm{AChE} / \mathrm{BuChE}$ (Fig. 16). Thus, derivative 51 shows micro- or sub-micromolar activities at both targets and excellent selectivity over CB1 and AChE, respectively [187].

\section{Cannabinoid System in Alzheimer's disease}

Alzheimer's disease (AD) is a progressive neurodegenerative disorder defined as the loss of cognitive functions of sufficient severity to impair social and occupational functioning. It affects intellectual abilities such as memory, thinking, orientation, comprehension, calculation, learning capacity, language, and judgement. $\mathrm{AD}$ is usually chronic and irreversible and is currently the most common cause of dementia in the elderly, accounting for probably $60-70 \%$ of all dementias worldwide, followed by vascular dementia, mixed dementia, and Lewy body dementia.

In 2015, epidemiological data estimated that the worldwide prevalence of dementia is around 47 million people and there are almost 9,9 million new cases annually, according to WHO data. According to these data, the number of people affected by 2030 will be 75 million and will be 132 million by 2050 (see [188] and references therein).

It is, therefore, to be expected that the cost of taking care of these patients can be enormous, considering the actual level of incidence and future generations of patients affected by AD. Physical, emotional and economic pressures can cause great stress to families and carers, and support is required from the health, social, financial and legal systems. Besides the monetary cost, it is impossible to quantify the suffering of the families that take care of people with AD during years. Nevertheless, in 2015, the total global cost of dementia was estimated at US\$ 818 billion. Despite the devastating effects of this disease, therapeutic options for treating $\mathrm{AD}$ remain limited, even though the drugs commonly prescribed today as a treatment for $\mathrm{AD}$ only provide temporary benefits related to improvement of symptoms, but do not prevent disease progression with only temporary benefit. Currently, cholinergic drugs like acetylcholinesterase (AChE) inhibitors, including donepezil, rivastigmine, and galantamine (Fig. 17), are currently the most prescribed pharmaceuticals for AD [189-192], even though their therapeutic use remains limited to a symptomatic approach. The only alternative for the treatment of the Alzheimer's disease in the moderate to severe stages is Memantine, a non-competitive antagonist of the glutamatergic NMDA receptor [193]. 
<smiles>COc1ccc2c3c1O[C@@H]1C[C@@]3(C=C[C@@H]1O)CN(C)C2</smiles>

Galantamine<smiles>CCN(C)C(=O)Oc1cccc(C(C)N(C)C)c1</smiles>

Rivastigmine
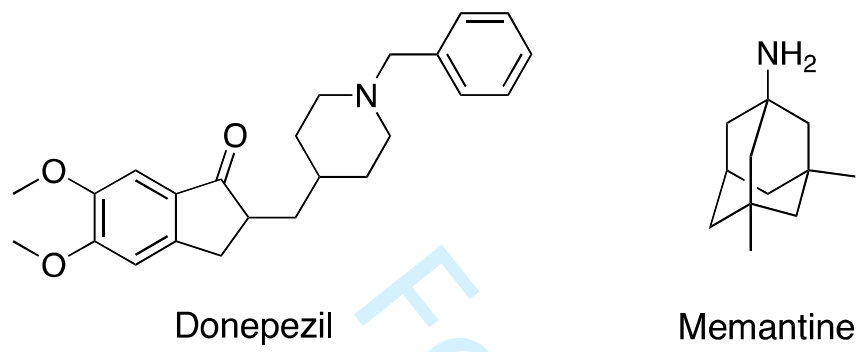

Memantine

Fig. (17). Therapeutic drug used to treatment Alzheimer's disease

Alzheimer's disease is a process characterised morphologically by the presence of senile plaques (fibrillar $\beta$-amyloid) and by the presence of neurofibrillary tangles (hyperphosphorylated and nitrated tau proteins).

Neuritic plaques are extracellular lesions composed of a central core of aggregate amyloid- $\beta$ peptide whose accumulation in the brain that is produced proteolytically from the amyloid precursor protein (APP) initiates a cascade of events that originate neuronal dysfunction, neurodegeneration and dementia. Neurofibrillary tangles NFTs are intracellular aggregated hyperphosphorylated forms of the microtubule-associated protein tau. Although the aetiology of these diseases has not been completely defined, both $\mathrm{A} \beta$ and hyperphosphorylated tau promote the progression of the pathological process, as these abnormal proteins are accumulated in the brain [194, 195]. Additionally other factors that include neuroinflammation, excitotoxicity and mitochondrial dysfunction that increase the production of reactive oxygen and nitrogen species (ROS and RNS) are involved in the pathogenesis of AD, meaning they could be used therapeutically.

Endocannabinoid signalling has been demonstrated to modulate the main pathological effects occurring during the neurodegenerative process that include protein misfolding, neuroinflammation, excitotoxicity, mitochondrial dysfunction, and oxidative stress [196].

\subsection{Cannabinoid Agonists on Alzheimer's disease}

The endocannabinoid system suffers profound changes during neurodegenerative and neuroinflammatory disorders. The expressions of $\mathrm{CB} 1$ and $\mathrm{CB} 2$ receptors as well as biosynthesis of endocannabinoids are deeply affected (for reviews see [195, 197-200]).

Regarding CB1 receptors, a progressive loss of specific populations of neurons that express CB1 receptors during neurodegenerative processes, particularly in the hippocampus and basal ganglia, has been described [201],[202]. In line with these results, a decrease in CB1 receptor expression in the 
triple transgenic mouse model of AD has been reported [203].

A large number of studies support the fact that the CB2 receptors are involved in AD pathology. In this sense, the physiological response mediated by the Endocannabinoid system is to counteract inflammation and therefore the CB2R activation [204, 205]. CB2 receptors are generally less expressed in the neurons of healthy brains, but their expression increases dramatically in reactive microglia and activated astrocytes during neuroinflammation [196, 206].

Thus, post-mortem brains from patients with $\mathrm{AD}$ have shown that $\mathrm{CB} 2$ receptors are up-regulated in cells that are associated with $A \beta$-enriched neuritic plaques [201, 202, 207, 208].

Moreover, transgenic models of $\mathrm{AD}$ have also revealed the over-expression of $\mathrm{CB} 2$ receptors in brain areas affected by AD-pathology [209]. Moreover, an increase in CB2 receptors was also observed in rats and C6 astroglioma cells pre-treated with $A \beta 42$ [197, 210].

During the last few years, interesting and elegant studies have allowed new perspectives to be opened in the prevention and/or treatment of $\mathrm{AD}$, with particular focus on cannabinoid receptor ligands (see reviews: [195, 197-199, 211-214]).

The reduction in CB1 receptors associated with neuronal loss along with the psychotropic effects of CB1 receptor agonists are the reasons why they are not usually considered plausible targets for neuroprotection.

In this context, this review will focus on the most recent and relevant publications of cannabinoid receptor agonists from the medicinal chemistry point of view published highlighting the last years, underlining the effect of $\mathrm{CB} 2$ agonists as candidates for $\mathrm{AD}$.

A great variety of studies have provided experimental evidence about the potential therapeutic properties of cannabinoid receptor agonists in cellular models that simulate the different effects of AD. Most of these assays are focused on studying the capacity of $\mathrm{CB} 2$ receptors to modulate $A \beta$ and hyperphosphorylated tau levels and the anti-inflammatory properties of CB2 agonists.

\subsubsection{Effect of cannabinoids agonist on $A \beta$}

Many in vitro studies in models of neuronal damage about the neuroprotective properties of endogenous and exogenous cannabinoids have been reported. Thus, endocannabinoids such as anandamide (AEA) and noladin ether, directly supplied to the cell culture or augmenting their availability through the administration of endocannabinoid reuptake inhibitors, are potent in vitro inhibitors of A $\beta$-toxicity, being effective at nanomolar concentrations [215]. However, the authors have concluded that these effects are exerted through a CB1-dependent, MAPK-mediated mechanism [215]. Other in vitro studies have shown that the endocannabinoid anandamide (AEA) protects neurons from inflammatory damage by $\mathrm{CB} 1 / \mathrm{CB} 2$ receptor-mediated rapid induction of mitogenactivated protein kinase phosphatase-1 (MAKP-1) in microglial cells [216].

Regarding the phytocannabinoids, several in vitro studies have suggested a direct effect of THC on the reduction of $A \beta$ aggregation and on the promotion of $A \beta$ degradation $[217,218]$. Similar results about the survival of neuronal cultures exposed to A $\beta$ peptide were obtained with $\mathrm{CBD}$ [219] and with 2-AG 
[218].

Moreover, several studies have shown that the mixed CB1/CB2 receptor agonists WIN55,212-2 (Fig. 6) and HU-210 (Fig. 8), and the selective agonists JWH-015 (Fig. 6), JWH-133 (Fig. 8), and HU-308

(Fig. 2) reduce the release of pro-inflammatory cytokines in microglial cell cultures exposed to different toxic $\mathrm{A} \beta$ peptides [220,221].

Thus, HU-210 was capable of preventing A $\beta 1-40$-induced changes in microglial morphology and HU210, WIN55,212-2 and JWH-133 significantly inhibited the microglial production of TNF- $\alpha$, a known cytokine that participates in A $\beta$-triggered damage [201]. Moreover, JWH-133 and WIN55,212-2 promote microglial migration, which facilitates the phagocytosis of aggregated $\mathrm{A} \beta$ [221].

The protective properties of WIN55,212-2 were also demonstrated in A $\beta$-induced neurodegeneration in the rat hippocampus. WIN55,212-2 significantly improved memory functions and decreased the elevated levels of neuroinflammatory markers like TNF- $\alpha$, activated caspase-3, and nuclear NFкB [222]. Moreover, WIN55,212-2, through CB2 receptors, inhibited iNOS and NO production, the release of chemokines (CXCL10, CCL2, and CCL5) and TNF- $\alpha$ from IL-1 $\beta$-activated human foetal astrocytes [223].

Regarding the selective CB2 agonist, JWH-015 induced a decrease in CD40 receptor expression by mouse microglial cells in primary culture after exposure to interferon-gamma and prevented the A $\beta$ triggered production of pro-inflammatory cytokines [220]. In this sense, activation of CB2 receptors with the selective agonist JWH-015 facilitates $\mathrm{A} \beta$ phagocytosis by human macrophages in brain sections obtained from AD patients [224].

\subsubsection{Effect of cannabinoid agonist on Tau hyper-phosphorylation}

Different studies have been carried out to clarify the role of CB2 receptors in the modulation of tau hyper-phosphorylation. Thus, studies performed in cell cultures demonstrated that CBD inhibits hyperphosphorylation of the tau protein in A $\beta$-stimulated PC12 neuronal cells [225].

Other studies have shown that THC is able to reduce tau phosphorylation in N2a/APPswe cells [226]. Moreover, it has been shown that pre-treatment with CBD prevented the expression of proteins that are potentially involved in tau phosphorylation and A-beta production in GMSCs [227].

Early studies performed in cell cultures demonstrated that the mixed CB1-CB2 agonist WIN55,212-2 inhibited tau protein hyper-phosphorylation in A $\beta$-stimulated PC12 neuronal cells, but that this effect was mainly mediated by CB1 receptors. Moreover, a selective CB2 agonist JWH015 failed to modify tau hyper-phosphorylation under the same experimental conditions [228]. Nevertheless, JWH133, a selective agonist of CB2R, reduces the phosphorylation of tau and GSK3ß activity in HEK293 tau cells, but the effects of JWH133 on phosphorylation of tau and GSK3ß disappeared with compound C (AMPK inhibitor) or Prkaa2-RNAi [229].

\subsubsection{Effect of cannabinoid agonist involved in other mechanism of AD}

In addition to the above-described effects, other non-receptor-mediated roles of cannabinoids have been published. Thus, in relation to the cholinergic receptor, several studies have been published. 
Thus, THC competitively inhibits AChE, preventing AChE-induced A $\beta$ aggregation by binding in the peripheral anionic site of $\mathrm{AChE}$, the critical region involved in amyloidogenesis [217].

Other studies have shown that cannabinoid agonists as THC and JWH133 are AChE inhibitors, showing a mixed type inhibition mode of action [230]. The non-selective agonists THC and the synthetic analogue $\mathrm{CP}-55,940$ behave as inhibitors of $\mathrm{AChE} / \mathrm{BuChE}$, with marked selectivity for $\mathrm{AChE}$ or $\mathrm{BuChE}$, respectively. The non-selective agonist CP-55,940 showed non-competitive inhibition, suggesting that this cannabinoid only binds to the peripheral site.

Nevertheless, analogues of natural cannabinoids, such as JWH-133 and indazole JWH-015, both with a high degree of selectivity for $\mathrm{CB} 2$ receptors, have shown inhibition only against $\mathrm{AChE}$ or $\mathrm{BuChE}$, respectively [230].

\subsubsection{Cannabinoids Agonists toward the clinic}

A considerable number of biological studies have been performed with a small group of cannabinoid agonists with different animal models (Table 2). The tested cannabinoids include endocannabinoids such as anandamide and noladin ether, phytocannabinoids such as $\triangle 9$-THC, cannabidiol (CBD) (Fig. 1), and synthetic cannabinoids such as WIN55,212-2 (Fig. 6), JWH-133, HU-210 (Fig. 8), ßcaryophyllene (Fig. 1) and MDA7 (Fig. 13).

Several studies have been performed using $A \beta$ administration directly into the CNS in different transgenic animal models. Thus, endocannabinoids such as anandamide (AEA) and noladin ether, have shown that reduced $A \beta$-induced memory impairment in rats [231].

The neuroprotective properties of phytocannabinoids have also been demonstrated to prevent memory deficits in $\mathrm{A} \beta$-injected rats and mice for mixed $\mathrm{CB} 1 / \mathrm{CB} 2$ receptor agonists such as $\triangle 9-\mathrm{THC}$ and cannabidiol (CBD).

Thus, it has been shown that $\triangle 9$-THC significantly reduced $\mathrm{A} \beta$ and neurodegeneration in 5XFAD transgenic mice and that these effects are preserved in the presence of COX-2 inhibition and also elevates expression of neprilysin, an important endopeptidase for $\mathrm{A} \beta$ degradation [232].

On the other hand, it has been shown that the combination of THC and CBD exhibits a better therapeutic profile than each separately [233]. Thus, a combination of $\triangle 9-\mathrm{THC}$ and CBD reduced learning impairment and caused a significant decrease in soluble $A \beta 42$ peptide levels and a change in plaque composition in A $\beta P P / P S 1$ mice [233].

Moreover, a reduction of free radicals and mitochondrial activity was also suggested in a mouse model of tauopathy exposed to chronic treatment with the Sativex ${ }^{\circledR}$ mixture of $\Delta 9$-THC and CBD [234], although no evidence of the direct implication of CB2 receptors or other receptors in such effects was provided. Therefore, $\triangle 9$-THC and CBD natural mixture present in Sativex ${ }^{\circledR}$, even after a short administration in animals with present behavioural and pathological abnormalities, improves the phenotype, oxidative stress, and deposition of proteins.

Additionally, CBD is capable of attenuating $\mathrm{A} \beta$ evoked neuroinflammatory responses. Thus, $\mathrm{CBD}$ inhibited GFAP mRNA and protein expression in mice inoculated with human A $\beta$ (1-42) peptide into 
the right dorsal hippocampus. Also, CBD impaired iNOS and IL-1beta protein expression, and the related NO and IL-1beta release [235].

Likewise, different studies with synthetic cannabinoid agonists have demonstrated their neuroprotective properties. Thus, both CBD and WIN55,212-2, after subchronic administration for 3 weeks, were able to prevent the learning of a spatial navigation task and cytokine gene expression in $\beta$-amyloid-injected mice. The studies show that CBD is able to modulate microglial cell function in vitro and induce beneficial effects in an in vivo model of $\mathrm{AD}$ [221].

Other studies have reported that the CB1/CB2 cannabinoid agonist WIN55,212-2 prevented the cognitive impairment and loss of neuronal markers induced by $\beta$ A25-3 i.c.v. administration to Wistar rats. In addition to this, microglial activation was also prevented by WIN55,212-2 administration. It is currently well-known that microglia play a pivotal role in the response to amyloid deposition, modulating the immunological response of the brain. It seems reasonable to think that the reported prevention of microglial activation also collaborates in the neuroprotective effect of WIN55,212-2 in this rat model of $\mathrm{AD}[201]$.

Other studies with WIN55212-2 have shown decreased A $\beta$-induced neuroinflammation in rats through the activation of both CB1 and CB2 cannabinoid receptors and the PPAR-gamma pathway [222]. This agonist significantly improved memory functions and decreased the elevated levels of neuroinflammatory markers like TNF- $\alpha$, activated caspase-3, and nuclear NFkB. The use of antagonists confirmed that neuroprotective effects were partially mediated by CB1 and CB2 receptors [222]. Moreover, JWH-133 and WIN55,212-2 significantly reduced the levels of COX-2, TNF- $\alpha$, and increased A $\beta$ clearance (Martin-following prolonged oral administration in Tg APP mice [236]).

However, a study where WIN55,212-2 and the selective CB2 cannabinoid receptor agonist JWH-133 were evaluated indicated that JWH-133 was able to reduce cognitive impairments and decrease microglial activation in Tg2576 mice, while WIN55,212-2 was ineffective [236].

The vascular response of the CB1/CB2 cannabinoid receptor agonist WIN 55,212-2 and the CB2 selective agonist JWH-133 has been studied in Tg APP mice. The results have shown that both cannabinoid agonists were able to prevent decreased $A C h$ relaxation in the presence of $A \beta$ [237].

On the other hand, the selective CB2 cannabinoid receptor agonist JWH-133 has been evaluated in double A $\beta$ PP/PS1 transgenic mice, a genetic model of Alzheimer's disease. The results obtained indicate that JWH-133 was able to reduce cognitive impairments associated with decreased microglial reactivity and the reduced expression of pro-inflammatory cytokines IL-1 $\beta$, IL- 6 , TNF- $\alpha$, and IFN- $\gamma$. In addition, JWH-133 lowered tau hyper-phosphorylation in the vicinity of $\mathrm{A} \beta$ plaques. Moreover, JWH-133 produced a decrease in the expression of hydroxynonenal adducts derived from lipid peroxidation, and enhanced the expression of SOD1 and SOD2 around plaques. In contrast, the chronic treatment with JWH-133 failed to modify the A $\beta$ production or deposition in cortex and hippocampus [238].

Surprisingly, a study performed with a very potent $\mathrm{CB} 1 / \mathrm{CB} 2$ receptor agonist cannabinoid HU-210 
showed that it did not improve water maze performance and a contextual fear conditioning task in an APP23/PS45 double transgenic mouse model of AD. Furthermore, HU-210 did not show any effect on APP processing and A $\beta$ generation, as well as neuritic plaque formation in the brains of transgenic mice [239].

A different full selective CB2 receptor agonist as B-caryophyllene has been studied in APP/PS1 mice [240]. This CB2 agonist prevented cognitive impairment associated with reduced A $\beta$ burden in both the hippocampus and the cerebral cortex. Moreover, beta-caryophyllene reduced astrogliosis and microglial activation as well as the levels of COX-2 protein and the mRNA levels of the proinflammatory cytokines TNF- $\alpha$ and IL-1 $\beta$ in the cerebral cortex [240]. The results obtained indicate that the anti-inflammatory effect of the $\beta$-caryophyllene involves $\mathrm{CB} 2$ receptor activation and the PPAR- $\gamma$ pathway since the effect is reversed by the CB2 antagonist AM630 or the PPAR- $\gamma$ antagonist GW9662 [240].

Other selective CB2 receptor agonists such as the MDA7 have been performed in a model where the effects are induced by the bilateral microinjection of $A \beta(1-40)$ fibrils into the hippocampal CA1 area of rats [241]. The results indicated an improvement of the expression of CD11b (microglia marker) and glial fibrillary acidic protein (astrocyte marker), and a reduction of the secretion of IL-1 $\beta$, and the increase of $\mathrm{CB} 2$ receptors. Also, MDA7 promoted $\mathrm{A} \beta$ clearance and an improvement in synaptic plasticity, cognition, and memory [241].

Finally, the protective properties of multi-target CB2 cannabinoid agonist NP137 were also demonstrated in A $\beta$-induced neurodegeneration in TgAPP mice. Moreover, NP43 reduced the levels of iNOS and COX-2 protein, and the levels of the pro-inflammatory cytokines TNF- $\alpha$ and IL1b in the cerebral cortex using the 5xFAD mice as model of AD [186].

\section{Cardiovascular disorder and atherosclerosis}

Cardiovascular diseases (CVDs) are a group of disorders of the heart and blood vessels, including cerebrovascular disease, atherocleroccoronary heart, and rheumatic heart among others. Heart attacks and strokes are usually acute events and are mainly caused by a blockage that prevents blood from flowing to the heart or brain. The most common reason for this is a build-up of fatty deposits on the inner walls of the blood vessels that supply the heart or brain. Strokes can also be caused by bleeding from a blood vessel in the brain or from blood clots. The cause of heart attacks and strokes are usually the presence of a combination of risk factors, such as tobacco use, unhealthy diet and obesity, physical inactivity and harmful use of alcohol, hypertension, diabetes and hyperlipidaemia. CVDs are still the leading cause of death worldwide. An estimated 17.7 million people died from CVDs in 2015, representing $31 \%$ of all global deaths. Of these deaths, an estimated 7.4 million were due to coronary heart disease and 6.7 million were due to stroke (WHO 2017).

During the last years, an important number of studies have provided evidence, on the one hand, the role of over-production of endocannabionid levels in cardiovascular pathophysiology such as hypotension, different forms of shock, and also in the cardiovascular abnormalities that accompany 
cirrosis is reported [242]. On the other hand, cannabinoids have also been associated with cardiovascular beneficial effects, such as a protective role in the progression of atherosclerosis and after myocardial ischaemia [243].

Endocannabinoids in the cardiovascular system cause hypotension, bradycardia mediated via CB1 receptors and negative inotropy [244]. In the cardiovascular system CB2 receptor expression has been established in the myocardium and cardiomyocytes, cardiomyoblasts and in human coronary artery endothelial and smooth muscle cells $[245,246]$. The CB2 receptor has a compensatory role. Activation of the CB2 receptor exerts an anti-inflammatory, anti-oxidative, and anti-atherogenic role, contributing to cardiovascular protection [247]. For instance, inflammatory processes or tissue injury show increased levels of CB2 expression. CB2 signalling in the heart and vasculature may activate cardioprotective mechanisms and protect against inflammation.

\subsection{Atherosclerosis}

As commented on above, CVDs are one of the leading cause of death and disability worldwide and can be largely attributed to atherosclerosis. It is a chronic inflammation of the arteries characterised by the presence of the lesions that contain immune cells, lipid-laden macrophages (foam cells), cholesterol, smooth muscle cells, and collagen fibres. The physical rupture of the plaques causes the occlusion of arteries, which can lead to tissue infarction [245, 248-250]. The key role of the inflammation in atherosclerosis has gained relevance during the last years (see reviews [251-253]) In this sense, the CB2 receptor is known to decrease the production of numerous chemokines and to inhibit leukocyte migration in vitro and in vivo; it emerged as a potential target to treat atherosclerosis. Since the initial studies performed by Steffens et al. in 2005 [254] proving the atheroprotective capacity of the $\triangle 9$-THC in mice model via CB2 receptor (Table 3), a great number of studies has been performed [243, 255] in experimental animal model (male ApoE-/- mice) in order to study both the CB2 receptor role in the diseases and the atheroprotective capacity of some agonist cannabinoids such as WIN55212-2 [256] (Fig. 6). In all of these studies, the beneficial effects of the treatment with the CB2 agonist were blocked by the CB2 antagonist, showing that CB2 receptor mechanisms (Table 3). Although most of the published studies confirm that the cannabinoid agonist shows an antiatherosclerotic effect through CB2 receptor activation, there are still some controversial results [257]. In conclusion, the clinical translation of CB2-based therapies still requires research to clarify the role of cannabinoid agonists in atherosclerosis.

\subsection{Acute cardiac ischaemic/reperfusion}

Ischaemic injury occurs when there is an interruption in the blood supply to an area of tissue. Tissue injury and/or death is determined primarily by the magnitude and duration of the interruption in the blood supply, and then subsequent damage induced by reperfusion [258]. The incidence of ischaemic/reperfusion ( $\mathrm{I} / \mathrm{R})$ injury is vast: myocardial infarction, stroke, and other thrombotic events. It has been proposed that oxidative stress and inflammatory responses play an important role in the initiation of vulnerable plaque disruption and subsequent development of acute miocardial ischaemic 
[259]. During recent years, different studies have proven that the endocannabinoid system is involved in different forms of ischaemia/reperfusion injury. On the one hand, there is an over-production of endocannabinoids contributing to the cardiovascular depressive state associated with these diseases [260]. On the other hand, endocannabinoids have been proposed to protect against myocardial ischemia/reperfusion injury through $\mathrm{CB} 2$ receptor in protecting against myocardial, cerebral and hepatic ischemia/reperfusion injury [243, 260, 261]. The activation of CB2 receptor in injured myocardium produces different protectives responses. It has been shown that the activation of CB2 receptor produces the suppression of the inflammatory response as shown in decreased expression of adhesion molecules, secretion of chemokine, leukocyte chemotaxis among others [255, 260, 262]. Likewise, the $\mathrm{CB} 2$ receptor activation produces a protective role regarding stress oxidative decreasing levels of reactive oxygen species [259, 263, 264].

Table 3 collets the different experimental studies of the role of agonists CB2 in myocardial ischemia/reperfusion injury in vivo models showing both an inflammatory response as well as oxidative stress protection [259, 265-270].

\subsection{Acute ischaemic stroke injury}

The human costs of stroke are very large and growing. Survivors are often faced with a loss of ability to function independently. The interruption of cerebral blood flow, regardless of the cause, results in a reduction of nutrient delivery to the brain, ultimately leading to ischaemic cell death [271].

In ischaemic stroke, an acute obstruction of blood cerebral flow, followed by reperfusion, unleashes a cascade of molecular and cellular inflammatory successes, which may lead to neuronal death. In the majority of cases, the obstruction is transient and cell death does not occur immediately. The delay between the initial insult and the cellular damage is variable, from hours to days or even weeks, depending upon the nature of the insult and the brain region affected. An important implication of this delay is that the introduction into the brain of protective therapeutic agents during this critical period could disrupt the cascade of damaging events and salvage vulnerable brain tissue.

Various research groups have investigated the role of CB2 receptors studying the effects of different CB2 ligands or employing knockout mice in experimental models of stroke [272-276] (Table 3). Similarly to the effects observed in myocardial ischaemia/reperfusion injury, CB2 receptor activation limited cerebral infarct size in experimental stroke by attenuating endothelial cell activation, chemokine signalling, inflammatory cell infiltration, glial activation, oxidative/nitrative stress and consequent cell death. Most of these beneficial effects could be blocked by CB2 receptor antagonists and/or were absent in CB2 knockout mice, evidencing the protective role of the endocannabinoid system through $\mathrm{CB} 2$ receptors.

Very recently, Bravo-Ferrer et al. have shown that CB2 receptor is fundamental for driving neuroblast migration suggesting that an endocannabinoid tone is required for post-stroke neurogenesis by promoting neuroblast migration toward the injured brain tissue, increasing the number of new cortical neurons and, conceivably, enhancing motor functional recovery after stroke [277]. 


\section{Autism spectrum disorders}

Autism spectrum disorder (ASD) is formed of a heterogeneous group of neurological disorders characterised by impaired social interaction and communication skills, and is often accompanied by other behavioural symptoms such as repetitive or stereotyped behaviour and abnormal sensory processing [278, 279]. Individual symptoms and cognitive functioning vary across the autism spectrum disorders.

The diagnosis is made during the first three years of age; however, the onset of disease can be from birth or usually during the second year. Some cases of ASD display genetic or chromosomal abnormalities, for instance Fragile X syndrome or Down syndrome. Most ASD cases have an unknown aetiology, although the existence of an abnormal development of brain connectivity has been accepted by the scientific community. Different studies have shown genetic evidence supporting a model of dysregulated axonal growth and guidance as key developmental processes underlying the clinical manifestations of ASD [280].

Neuroinflammation and immune system abnormalities have been shown to be associated with ASD. An active neuroinflammatory process was demonstrated in the post-mortem brain, mainly in the cerebral cortex, white matter, and cerebellum. Different studies have shown a key microglia activation and an increase of the inflammatory cytokine and chemokine production in the brain tissue and cerebral spinal fluid. It has been shown that autistic individuals have immune system abnormalities, specifically for antibodies against brain and CNS proteins and maternal proteins [278, 280]. Regarding the endocannabinoid system, both CB1 and CB2 receptors are involved in autism in different ways. CB1 receptors are expressed in those regions in the brain implicated as dysfunctional in autism, such as the cerebellum, hippocampus and basal ganglia. In addition, during development, CB1 receptors drive axon guidance and are responsible for synaptogenesis.

The CB2 receptors modulate immune cell functions, both in cellular and animal models of inflammatory diseases [281]. CB2R are responsible for responses to inflammatory injury, controlling the different inflammatory cells [281]. Zoppis et al. showed the regulatory role of the CB2R and agonist CB2 as JWH-133 in a stress-induced neuroinflammation mice model. They used three different models, wild type (WT), transgenic overexpressing $\mathrm{CB} 2$ receptors (CB2xP) and $\mathrm{CB} 2$ receptor knockout (CB2-KO) mice exposed to different stress mechanisms to check the role of $\mathrm{CB} 2$ receptor and JWH-133 (Fig. 8). JWH-133 prevented the stress-induced increase in pro-inflammatory cytokines (TNF- $\alpha$ and CCL2), in NF- $\mathrm{kB}$, and in NOS-2 and COX-2, and in the consequent cellular oxidative and nitrosative damage (lipid peroxidation). CB2xP mice exhibited anti-inflammatory or neuroprotective actions similar to those in JWH-133 pre-treated animals. Conversely, a lack of CB2 receptors (CB2-KO mice) exacerbated stress-induced neuroinflammatory responses and confirmed that the effects of JWH-133 were mediated through CB2 receptors [282]. 
1

2

3

4

5

6

7

8

9

10

\section{Bone disorders}

Bones, the highly specialised supporting framework of the body, are characterised among other aspects by the power of regeneration. Bones have two components: the cortical bone which is dense, solid, and surrounds the marrow space and the trabecular bone which is composed of a honeycomblike network of trabecular plates and rods interspersed in the bone marrow compartment.

Bone is composed of support cells, namely, osteoblasts and osteocytes; remodelling cells, namely, osteoclasts; and non-mineral matrix of collagen and non-collagenous proteins called osteoid, with inorganic mineral salts deposited within the matrix. During life, the bones undergo processes of longitudinal and radial growth, modelling (reshaping), and remodelling [283]. Bone remodelling can be divided into the following six phases (Fig. 18), namely, quiescent, activation, resorption, reversal, formation and mineralisation. Bone is a living tissue that is constantly being broken down and replaced; thus, the major common cause of most bone disorders is a mismatch between bone formation and bone resorption.

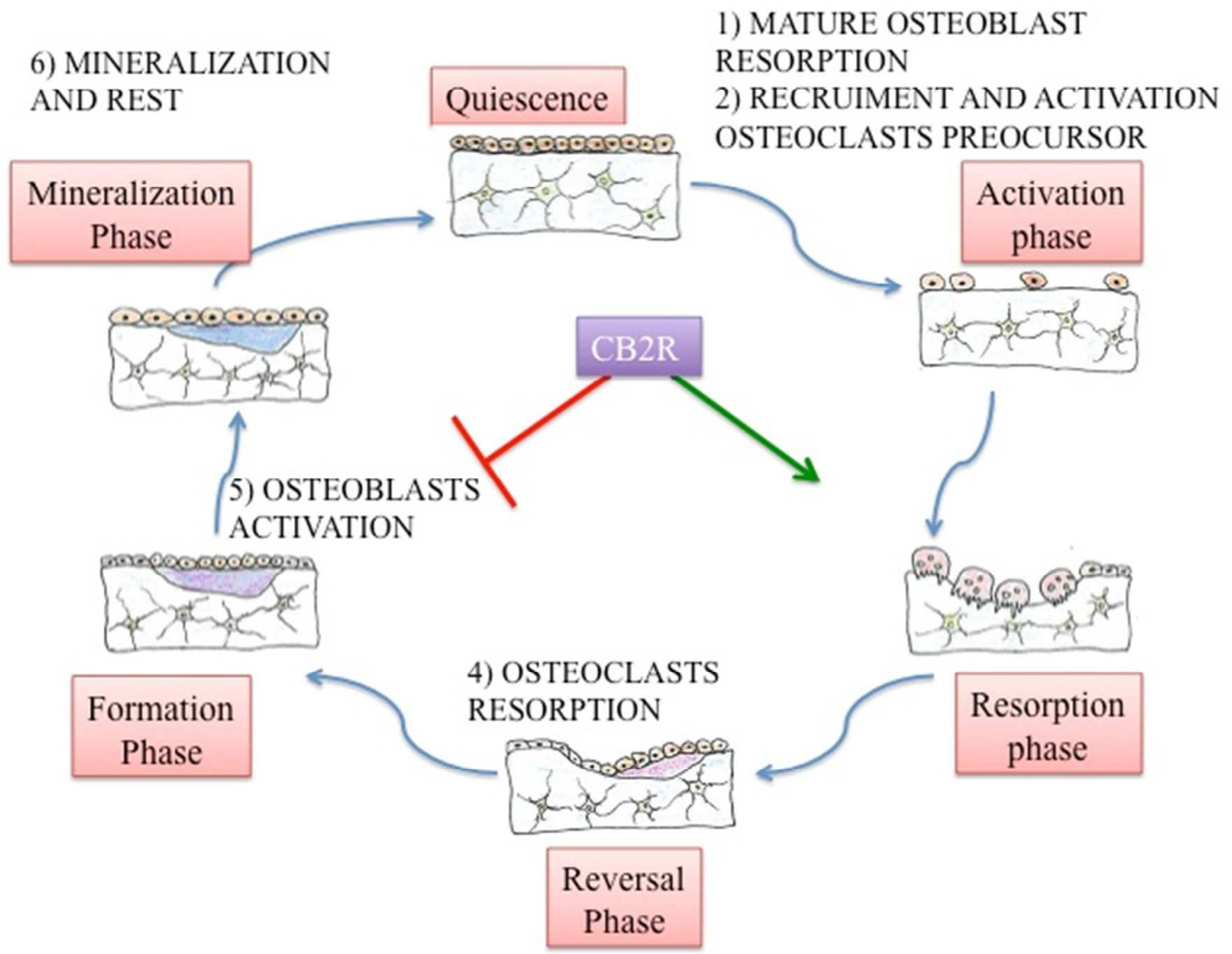

Fig. (18). Bone formation phases

One of the most common bone disorders is osteoporosis, which means "porous bone"; this is a metabolic disorder characterised by an imbalance in the activity of osteoblast and osteoclast. This means that osteoporosis occurs when the formation of new bone does not keep up with of old bone 
resorption; as a result, there is a deterioration of bone mass and enhanced bone fragility and fracture risk.

Several key components of the EC system have been identified in bone. Anandamide and 2-AG (Fig. 4) are present in bone at levels similar to those found in the brain [284]. In addition, both ligands are produced by osteoblasts and osteoclasts in culture. In a similar way, both CB1 and CB2 cannabinoid receptors are also present in the skeleton [285].

Studies of the role of CB1 have reported different effects that are age- and strain-dependent [286]. In this review, we focus on the role of $\mathrm{CB} 2$ receptor. Regarding CB2, several studies have indicated that the effect of CB2 in the skeletal is age- and strain-dependent but not gender-dependent. However, the effect is different in trabecular and cortical bond. In fact, the role of the CB2 receptor was not clear until recent years due to the contradictory results of published works. Different reasons could be responsible for these experimental inconsistencies, such as the species differences, off-target effects of CB2 receptor ligands at different concentrations, the activity of endogenous cannabinoids and the interactions of ligands with other receptors such as GPR55 [287].

Ofek et al. showed that CB2-deficient mice had developed an accelerated age-related trabecular bone loss and cortical expansion, which also characterises human osteoporosis. The CB2-/- phenotype is characterised by the increased activity of trabecular osteoblasts (bone-forming cells), increased osteoclast (the bone-resorbing cell) number and a decreased number of osteoblast precursors [288].

In vitro and in vivo studies showed that the agonist cannabinoid HU-308 (Fig. 2) and its enantiomer HU-433 are anti-osteoporotic, both in vitro and in vivo [114, 287]. Both agonists stimulate osteoblast proliferation, exhibiting a dose-response biphasic effect, with their effect being blocked by the CB2 receptor antagonist SR144528. Regarding in vivo experiments, the treatment of an ovariectomy (OVX)-induced bone loss mouse model with the agonist HU-433 showed a completely reversed OVXinduced decrease in bone volume density associated with the increased trabecular thickness and a higher trabecular number. Suggesting that CB2 signalling contributes to the maintenance of bone mass by two mechanisms: ( $i$ ) the direct stimulation of stromal cells/osteoblasts; and (ii) the inhibition of monocytes/osteoclasts, both directly and by the inhibition of osteoblast/stromal cell RANKL expression [287].

Other potential therapeutic applications of the CB2 receptor agonist is in relation to bone cancer. JWH015, a CB2 agonist, treatment significantly reduced serum markers of bone degradation in cancer animals and increases the markers of the serum bone formation marker, osteocalcin.

\section{Conclusions}

The eCS is a complex signalling system which has been implicated in a wide diversity of biological processes, in both the central and peripheral nervous systems. The CB1 cannabinoid receptors are the most abundant $\mathrm{G}$ protein-coupled receptors in the central neural system, expressed in both neurons and glial cells. Moreover, CB1 receptors are also found in peripheral tissues, such as the cardiovascular and reproductive systems as well as the gastrointestinal tract. CB2 receptors are mainly expressed in 
peripheral tissue and widely localised in cells of the immune system, as well as in other peripheral organs, such as the muscle, liver, intestine and testis. Likewise, in the nervous system, CB2 receptors are mainly located in microglia and in some neurons.

Therefore both receptors play significant functions in many biological processes, in normal and pathological conditions that affect the physiology and pathology in the central and peripheral nervous systems. Furthermore, the cannabinoid receptors may act as CB1-CB2 receptor heteromers in the brain and form heteromeric complexes with other G protein-coupled receptors [43-45].

All of these facts extremely complicate the development of novel drugs as a consequence of crosscorrelation between different biological systems.

The study of the function of homodimers and/or heterodimers for cannabinoid receptors is essential for discover novel drugs. Moreover, the possible cross-talk between endocannabinoid system and other endogenous systems is crucial to establish the potential therapeutics of cannabinoids.

In spite of numerous efforts to develop effective therapies to cure $A D$ or significantly inhibit the progression of $\mathrm{AD}$ symptoms, the studies have been unsuccessful. At present, many of the most promising current clinical trials for $\mathrm{AD}$ aimed at modifying disease progression are focused on $\mathrm{A} \beta$, the hyper-phosphorylation of tau and energy metabolism. The clinical trial studies include acetylcholinesterase inhibitors, $\beta$-secretase (BACE) or $\gamma$-secretase inhibitors, agonists and antagonists of neurotransmitter receptors (glutaminergic and serotonin receptors), vaccines or antibodies, as well as anti-inflammatory compounds.

Different studies have demonstrated the effect of cannabinoid agonists on $A B$, tau hyperphosphorylation and inflammation. Cannabinoid agonists reduced $\mathrm{A} \beta$-induced memory impairment, and attenuated neuroinflammatory responses; therefore, the use of $\mathrm{CB} 2$ receptor agonists offers an interesting, novel and promising therapeutic approach for AD. In this sense, with the current state of the art methods, it is difficult to understand why a CB2 cannabinoid receptor agonist has not already been studied in clinic phases.

There are some reasons that could explain the difficulty of translating research to the development of efficacious drugs in the clinic.

a) The complexity of eCS makes it extremely difficult to accurately predict the action of drugs. In fact, minor modifications of substituents in different scaffolds determined a functionality switch from agonist to antagonists/inverse agonists and of course in the selectivity of CB1/CB2.

b) $\mathrm{CB} 1$ receptor agonists are psychotropics and therefore it is necessary to remove that effect.

c) Most of the knowledge acquired about in vivo cannabinoid receptor pharmacology was obtained from the study of the mechanisms of action of a very small number of cannabinoids as mixed CB1/CB2 phytocannabinoids ( $\triangle 9$-THC, CBD), mixed CB1/CB2 synthetic cannabinoids (WIN55,2122, HU-210) and selective CB2 agonist (JWH-133) cannabinoids. 
d) The promiscuity shown of several cannabinoid agonists with other receptors (AChE, BuChE, BACE-1, etc.) means that the extrapolation of results between different cannabinoids cannot be performed.

e) The development of new effective drugs targeting the CNS generally is an enormously complicated and difficult task, which is often accompanied by a very high failure rate. In fact, since 2003, no new drugs have been approved by the FDA for the treatment of AD and during this time over two hundred compounds have reached Phase II clinical trials, and some even Phase III.

In relation to alternative strategies, it should be mentioned that several genomics studies have shown redundancy in proteinaceous drug targets suggesting that a more promiscuous approach through the application of multi-targets drugs can have advantages. This topic is very attractive both in academia and in industry, and is an approach for the treatment of neurological disorders.

Throughout the review, we have been able to confirm that we are still far from having cannabinoid compounds approved for the treatment of these diseases.

Regarding $\mathrm{AD}$, it is evident that there is an urgent necessity for new and improved treatment options; therefore, additional efforts to develop better drugs need to be a priority. It seems particularly necessary to explore new targets as cannabinoid receptors and new strategies as "multi-target-directed ligands".

As for the rest of the disorders mentioned, in general, in our opinion, it is necessary to perform experimental studies both in vitro and in vivo with new characterised pure agonist and antagonist CB2 compounds.

\section{Author Contributions}

Páez J. A. and Campillo, N. E. contributed equally to this work.

\section{Author Information}

For Páez, J. A.: jpaez@iqm.csic.es, Madrid, Spain

For Campillo, N. E.: nuria.campillo@csic.es

\section{Acknowledgements}

Financial support from MINECO, Spain (grant no. CTQ2015-66313-R)

\section{Conflict of Interest}

The authors declare that they have no conflict of interest.

\section{References}

1. Li, H. L. The origin and use of Cannabis in eastern Asia linguistic-cultural implications. Econ. Botany 1974, (28), 293-301.

2. Li, H. L.; Lin, H. An archaeological and historical account of Cannabis in China. Econ Bot 1974, (28), 437-448.

3. Touw, M. The religious and medicinal uses of Cannabis in China, India and Tibet. $J$ Psychoactive Drugs 1981, 13 (1), 23-34.

4. Jiang, H. E.; Li, X.; Zhao, Y. X.; Ferguson, D. K.; Hueber, F.; Bera, S.; Wang, Y. F.; Zhao, L. C.; Liu, C. J.; Li, C. S. A new insight into Cannabis sativa (Cannabaceae) utilization from 2500-yearold Yanghai Tombs, Xinjiang, China. J Ethnopharmacol 2006, 108 (3), 414-22. 
5. Lozano, I. The Therapeutic Use of Cannabis sativa (L.) in Arabic Medicine. J. Cannabis Therapeutics 2001, 1, 63-70.

6. Russo, E. B. History of cannabis and its preparations in saga, science, and sobriquet. Chem Biodivers 2007, 4, 1614-1618.

7. Fasinu, P. S.; Phillips, S.; ElSohly, M. A.; Walker, L. A. Current Status and Prospects for Cannabidiol Preparations as New Therapeutic Agents. Pharmacotherapy 2016, 36 (7), 781-96.

8. O'Shaughnessy, W. B. The Bengal Dispensatory and Pharmacopoeia. in The Bengal Dispensatory and Pharmacopoeia. Bishop's College Press: 1841.

9. Mechoulam, R.; Shvo, Y. Hashish-I : The structure of Cannabidiol. Tetrahedron 1963, 19 (12), 2073-2078.

10. Gaoni, Y.; Mechoulam, R. The Isolation and Structure of A'-Tetrahydrocannabinol and Other Neutral Cannabinoids from Hashish J. Am. Chem. Soc. 1964, 86, 1646-1647.

11. Mechoulam, R.; Hanus, L. O.; Pertwee, R.; Howlett, A. C. Early phytocannabinoid chemistry to endocannabinoids and beyond. Nat. Rev. Neurosci. 2014, 15 (11), 757-64.

12. Devane, W. A.; Dysarz, F. A. 3rd; Johnson, M. R.; Melvin, L. S.; Howlett, A. C. Determination and characterization of a cannabinoid receptor in rat brain. Mol. Pharmacol. 1988, 34 (5), 605-13.

13. Herkenham, M.; Lynn, A. B.; Little, M. D.; Johnson, M. R.; Melvin, L. S.; de Costa, B. R.; Rice, K. C. Cannabinoid receptor localization in brain. Proc. Natl. Acad. Sci. U S A 1990, 87 (5), 1932-6.

14. Howlett, A. C. Inhibition of neuroblastoma adenylate cyclase by cannabinoid and nantradol compounds. Life Sci. 1984, 35 (17), 1803-10.

15. Howlett, A. C.; Fleming, R. M. Cannabinoid inhibition of adenylate cyclase. Pharmacology of the response in neuroblastoma cell membranes. Mol. Pharmacol. 1984, 26 (3), 532-8.

16. Howlett, A. C. Cannabinoid inhibition of adenylate cyclase. Biochemistry of the response in neuroblastoma cell membranes. Mol. Pharmacol. 1985, 27 (4), 429-36.

17. Howlett, A. C.; Qualy, J. M.; Khachatrian, L. L. Involvement of Gi in the inhibition of adenylate cyclase by cannabimimetic drugs. Mol. Pharmacol. 1986, 29 (3), 307-13.

18. Matsuda, L. A.; Lolait, S. J.; Brownstein, M. J.; Young, A. C.; Bonner, T. I. Structure of a cannabinoid receptor and functional expression of the cloned cDNA. Nature 1990, 346 (6284), 561-4.

19. Devane, W. A.; Hanus, L.; Breuer, A.; Pertwee, R. G.; Stevenson, L. A.; Griffin, G.; Gibson, D.; Mandelbaum, A.; Etinger, A.; Mechoulam, R. Isolation and structure of a brain constituent that binds to the cannabinoid receptor. Science 1992, 258 (5090), 1946-9.

20. Munro, S.; Thomas, K. L.; Abu-Shaar, M. Molecular characterization of a peripheral receptor for cannabinoids. Nature 1993, 365 (6441), 61-5.

21. Di Marzo, V.; Fontana, A. Anandamide, an endogenous cannabinomimetic eicosanoid: 'killing two birds with one stone'. Prostaglandins Leukot. Essent. Fatty Acids 1995, 53 (1), 1-11.

22. Maccarrone, M.; Bab, I.; Biro, T.; Cabral, G. A.; Dey, S. K.; Di Marzo, V.; Konje, J. C.; Kunos, G.; Mechoulam, R.; Pacher, P.; Sharkey, K. A.; Zimmer, A. Endocannabinoid signaling at the periphery: 50 years after THC. Trends Pharmacol. Sci. 2015, 36 (5), 277-96.

23. Aizpurua-Olaizola, O.; Elezgarai, I.; Rico-Barrio, I.; Zarandona, I.; Etxebarria, N.; Usobiaga, A. Targeting the endocannabinoid system: future therapeutic strategies. Drug Discov. Today 2017, 22 (1), 105-110.

24. Gonzalez, A.; Duran, L. S.; Araya-Secchi, R.; Garate, J. A.; Pessoa-Mahana, C. D.; Lagos, C. F.; Perez-Acle, T. Computational modeling study of functional microdomains in cannabinoid receptor type 1. Bioorg. Med. Chem. 2008, 16 (8), 4378-89.

25. McPartland, J.; Di Marzo, V.; De Petrocellis, L.; Mercer, A.; Glass, M. Cannabinoid receptors are absent in insects. J. Comp. Neurol. 2001, 436 (4), 423-9.

26. Campillo, N. E.; Paez, J. A. Cannabinoid system in neurodegeneration: new perspectives in Alzheimer's disease. Mini Rev. Med. Chem. 2009, 9 (5), 539-59.

27. Svizenska, I.; Dubovy, P.; Sulcova, A. Cannabinoid receptors 1 and 2 (CB1 and CB2), their distribution, ligands and functional involvement in nervous system structures - A short review. Pharmacol. Biochem. Behav. 2008. 
28. Herkenham, M.; Groen, B. G.; Lynn, A. B.; De Costa, B. R.; Richfield, E. K. Neuronal localization of cannabinoid receptors and second messengers in mutant mouse cerebellum. Brain Res. 1991, $552(2), 301-10$.

29. Pertwee, R. G. Cannabinoid receptors and pain. Prog Neurobiol 2001, 63 (5), 569-611.

30. Szabo, B.; Nordheim, U.; Niederhoffer, N. Effects of cannabinoids on sympathetic and parasympathetic neuroeffector transmission in the rabbit heart. J. Pharmacol. Exp. Ther. 2001, 297 (2), 819-26.

31. Wagner, J. A.; Jarai, Z.; Batkai, S.; Kunos, G. Hemodynamic effects of cannabinoids: coronary and cerebral vasodilation mediated by cannabinoid $\mathrm{CB}(1)$ receptors. Eur. J. Pharmacol. 2001, 423 (2-3), 203-10.

32. Pertwee, R. G. Pharmacology of cannabinoid CB1 and CB2 receptors. Pharmacol Ther 1997, 74 (2), 129-80.

33. Croci, T.; Manara, L.; Aureggi, G.; Guagnini, F.; Rinaldi-Carmona, M.; Maffrand, J. P.; Le Fur, G.; Mukenge, S.; Ferla, G. In vitro functional evidence of neuronal cannabinoid CB1 receptors in human ileum. Br. J. Pharmacol. 1998, 125 (7), 1393-5.

34. Spoto, B.; Fezza, F.; Parlongo, G.; Battista, N.; Sgro, E.; Gasperi, V.; Zoccali, C.; Maccarrone, M. Human adipose tissue binds and metabolizes the endocannabinoids anandamide and 2arachidonoylglycerol. Biochimie 2006, 88 (12), 1889-97.

35. Silvestri, C.; Di Marzo, V. The endocannabinoid system in energy homeostasis and the etiopathology of metabolic disorders. Cell Metab. 2013, 17 (4), 475-90.

36. Centonze, D.; Battistini, L.; Maccarrone, M. The endocannabinoid system in peripheral lymphocytes as a mirror of neuroinflammatory diseases. Curr. Pharm. De.s 2008, 14 (23), 2370-42.

37. Ashton, J. C.; Glass, M. The cannabinoid CB2 receptor as a target for inflammation-dependent neurodegeneration. Curr. Neuropharmacol. 2007, 5 (2), 73-80.

38. Miller, A. M.; Stella, N. CB2 receptor-mediated migration of immune cells: it can go either way. Br. J. Pharmacol. 2008, 153 (2), 299-308.

39. Basu, S.; Dittel, B. N. Unraveling the complexities of cannabinoid receptor 2 (CB2) immune regulation in health and disease. Immunol. Res. 2011, 51 (1), 26-38.

40. Cabral, G. A.; Griffin-Thomas, L. Emerging role of the cannabinoid receptor CB2 in immune regulation: therapeutic prospects for neuroinflammation. Expert. Rev. Mol. Med. 2009, 11, e3.

41. Van Sickle, M. D.; Duncan, M.; Kingsley, P. J.; Mouihate, A.; Urbani, P.; Mackie, K.; Stella, N.; Makriyannis, A.; Piomelli, D.; Davison, J. S.; Marnett, L. J.; Di Marzo, V.; Pittman, Q. J.; Patel, K. D.; Sharkey, K. A. Identification and functional characterization of brainstem cannabinoid CB2 receptors. Science 2005, 310 (5746), 329-32.

42. Fernandez-Ruiz, J.; Romero, J.; Velasco, G.; Tolon, R. M.; Ramos, J. A.; Guzman, M. Cannabinoid CB2 receptor: a new target for controlling neural cell survival? Trends Pharmacol. Sci. 2007, 28 (1), 39-45.

43. Callen, L.; Moreno, E.; Barroso-Chinea, P.; Moreno-Delgado, D.; Cortes, A.; Mallol, J.; Casado, V.; Lanciego, J. L.; Franco, R.; Lluis, C.; Canela, E. I.; McCormick, P. J. Cannabinoid receptors CB1 and CB2 form functional heteromers in brain. J. Biol. Chem. 2012, 287 (25), 20851-65.

44. Khurana, L.; Mackie, K.; Piomelli, D.; Kendall, D. A. Modulation of CB1 cannabinoid receptor by allosteric ligands: Pharmacology and therapeutic opportunities. Neuropharmacology 2017, 124, 3-12.

45. Vinals, X.; Moreno, E.; Lanfumey, L.; Cordomi, A.; Pastor, A.; de La Torre, R.; Gasperini, P.; Navarro, G.; Howell, L. A.; Pardo, L.; Lluis, C.; Canela, E. I.; McCormick, P. J.; Maldonado, R.; Robledo, P. Cognitive Impairment Induced by Delta9-tetrahydrocannabinol Occurs through Heteromers between Cannabinoid CB1 and Serotonin 5-HT2A Receptors. PLoS Biol. 2015, 13 (7), e1002194.

46. Moreno, E.; Chiarlone, A.; Medrano, M.; Puigdellivol, M.; Bibic, L.; Howell, L. A.; Resel, E.; Puente, N.; Casarejos, M. J.; Perucho, J.; Botta, J.; Suelves, N.; Ciruela, F.; Gines, S.; Galve-Roperh, I.; Casado, V.; Grandes, P.; Lutz, B.; Monory, K.; Canela, E. I.; Lluis, C.; McCormick, P. J.; Guzman, M. Singular Location and Signaling Profile of Adenosine A2A-Cannabinoid CB1 Receptor Heteromers in the Dorsal Striatum. Neuropsychopharmacol. 2017.

47. Ross, R. A. The enigmatic pharmacology of GPR55. Trends Pharmacol. Sci. 2009, 30 (3), $156-63$. 
48. Pertwee, R. G. Receptors and channels targeted by synthetic cannabinoid receptor agonists and antagonists. CurrMedChem 2010, 17 (14), 1360-81.

49. Ibsen, M. S.; Connor, M.; Glass, M. Cannabinoid CB1 and CB2 Receptor Signaling and Bias. Cannabis Cannabinoid Res. 2017, 2 (1), 48-60.

50. Pistis, M.; Melis, M. From surface to nuclear receptors: the endocannabinoid family extends its assets. CurrMedChem 2010, 17 (14), 1450-67.

51. O'Sullivan, S. E. An update on PPAR activation by cannabinoids. Br. J. Pharmacol. 2016, 173 (12), 1899-910.

52. Alexander, S. P.; Kendall, D. A. The complications of promiscuity: endocannabinoid action and metabolism. Br. J. Pharmacol. 2007, 152 (5), 602-23.

53. Di Marzo, V.; De Petrocellis, L. Endocannabinoids as regulators of transient receptor potential (TRP) channels: A further opportunity to develop new endocannabinoid-based therapeutic drugs. CurrMedChem 2010, 17 (14), 1430-49.

54. a) Greenshaw, A.J. Behavioural pharmacology of 5-HT3 receptor antagonists: a critical update on therpaeutic potencial. Trends, Pharmacol. Scie. 1993, 14, 265-270. b) Pertwee, R.G. Endocannabinoids and their pharmacological actions. Handb. Exp. Pharmacol. 2015, 231, 1-37. c) Rodriguez-Munoz, M.; Sanchez-Blazquez, P.; Merlos, M.; Garzon-Nino, J. Endocannabinoid control of glutamate NMDA receptors: the therapeutic potential and consequences of dysfunction. Oncotarget 2016, 7 (34), 55840-55862.

55. Solinas, M.; Goldberg, S. R.; Piomelli, D. The endocannabinoid system in brain reward processes. Br. J. Pharmacol. 2008, 154 (2), 369-83.

56. Chiu, C. Q.; Puente, N.; Grandes, P.; Castillo, P. E. Dopaminergic modulation of endocannabinoid-mediated plasticity at GABAergic synapses in the prefrontal cortex. J. Neurosci. 2010, 30 (21), 7236-48.

57. Franklin, J. M.; Carrasco, G. A. Cannabinoid receptor agonists upregulate and enhance serotonin 2A (5-HT(2A)) receptor activity via ERK1/2 signaling. Synapse 2013, 67 (3), 145-59.

58. Nasehi, M.; Farrahizadeh, M.; Ebrahimi-Ghiri, M.; Zarrindast, M. R. Modulation of cannabinoid signaling by hippocampal 5-HT4 serotonergic system in fear conditioning. $J$. Psychopharmacol. 2016, 30 (9), 936-44.

59. Hu, B.; Bai, F.; Xiong, L.; Wang, Q. The endocannabinoid system, a novel and key participant in acupuncture's multiple beneficial effects. Neurosci. Biobehav. Rev. 2017, 77, 340-357.

60. Glass, M.; Northup, J. K. Agonist selective regulation of $\mathrm{G}$ proteins by cannabinoid $\mathrm{CB}(1)$ and CB(2) receptors. Mol. Pharmacol. 1999, 56 (6), 1362-9.

61. Felder, C. C.; Joyce, K. E.; Briley, E. M.; Mansouri, J.; Mackie, K.; Blond, O.; Lai, Y.; Ma, A. L.; Mitchell, R. L. Comparison of the pharmacology and signal transduction of the human cannabinoid CB1 and CB2 receptors. Mol. Pharmacol. 1995, 48 (3), 443-50.

62. Mechoulam, R.; Ben-Shabat, S.; Hanus, L.; Ligumsky, M.; Kaminski, N. E.; Schatz, A. R.; Gopher, A.; Almog, S.; Martin, B. R.; Compton, D. R.; et al. Identification of an endogenous 2monoglyceride, present in canine gut, that binds to cannabinoid receptors. Biochem. Pharmacol. 1995, 50 (1), 83-90.

63. Sugiura, T.; Kondo, S.; Sukagawa, A.; Nakane, S.; Shinoda, A.; Itoh, K.; Yamashita, A.; Waku, K. 2-Arachidonoylglycerol: a possible endogenous cannabinoid receptor ligand in brain. Biochem. Biophys. Res. Commun. 1995, 215 (1), 89-97.

64. Sugiura, T.; Waku, K. 2-Arachidonoylglycerol and the cannabinoid receptors. Chem. Phys. Lipids 2000, 108 (1-2), 89-106.

65. Childers, S. R.; Breivogel, C. S. Cannabis and endogenous cannabinoid systems. Drug Alcohol Depend. 1998, 51 (1-2), 173-87.

66. Hanus, L.; Abu-Lafi, S.; Fride, E.; Breuer, A.; Vogel, Z.; Shalev, D. E.; Kustanovich, I.; Mechoulam, R. 2-arachidonyl glyceryl ether, an endogenous agonist of the cannabinoid CB1 receptor. Proc. Natl. Acad. Sci. U S A 2001, 98 (7), 3662-5.

67. Porter, A. C.; Sauer, J. M.; Knierman, M. D.; Becker, G. W.; Berna, M. J.; Bao, J.; Nomikos, G. G.; Carter, P.; Bymaster, F. P.; Leese, A. B.; Felder, C. C. Characterization of a novel endocannabinoid, virodhamine, with antagonist activity at the CB1 receptor. J. Pharmacol. Exp. Ther. 2002, 301 (3), 1020-4. 
68. Grigorenko, E.; Kittler, J.; Clayton, C.; Wallace, D.; Zhuang, S.; Bridges, D.; Bundey, S.; Boon, A.; Pagget, C.; Hayashizaki, S.; Lowe, G.; Hampson, R.; Deadwyler, S. Assessment of cannabinoid induced gene changes: tolerance and neuroprotection. Chem. Phys. Lipids 2002, 121 (12), 257-66.

69. Hillard, C. J.; Jarrahian, A. The movement of N-arachidonoylethanolamine (anandamide) across cellular membranes. Chem. Phys. Lipids 2000, 108 (1-2), 123-34.

70. Maccarrone, M.; Dainese, E.; Oddi, S. Intracellular trafficking of anandamide: new concepts for signaling. Trends Biochem Sci 2010, 35 (11), 601-8.

71. Hillard, C. J. Biochemistry and pharmacology of the endocannabinoids arachidonylethanolamide and 2-arachidonylglycerol. Prostaglandins Other Lipid Mediat 2000, 61 (12), 3-18.

72. Vandevoorde, S. Overview of the chemical families of fatty acid amide hydrolase and monoacylglycerol lipase inhibitors. Curr. Top. Med. Chem. 2008, 8 (3), 247-67.

73. Di Marzo, V. Endocannabinoids: synthesis and degradation. Rev. Physiol. Biochem. Pharmacol. 2008, 160, 1-24.

74. Bari, M.; Battista, N.; Fezza, F.; Gasperi, V.; Maccarrone, M. New insights into endocannabinoid degradation and its therapeutic potential. Mini Rev. Med. Chem. 2006, 6 (3), 257-68.

75. Maccarrone, M. Fatty acid amide hydrolase: a potential target for next generation therapeutics. Curr. Pharm. Des. 2006, 12 (6), 759-72.

76. Makriyannis, A. 2012 Division of medicinal chemistry award address. Trekking the cannabinoid road: a personal perspective. J. Med. Chem. 2014, 57 (10), 3891-911.

77. Aghazadeh Tabrizi, M.; Baraldi, P. G.; Borea, P. A.; Varani, K. Medicinal Chemistry, Pharmacology, and Potential Therapeutic Benefits of Cannabinoid CB2 Receptor Agonists. Chem. Rev. 2016, 116 (2), 519-60.

78. Nimczick, M.; Decker, M. New approaches in the design and development of cannabinoid receptor ligands: multifunctional and bivalent compounds. ChemMedChem 2015, 10 (5), 773-86.

79. Spinelli, F.; Capparelli, E.; Abate, C.; Colabufo, N. A.; Contino, M. Perspectives of Cannabinoid Type 2 Receptor (CB2R) Ligands in Neurodegenerative Disorders: Structure-Affinity Relationship (SAfiR) and Structure-Activity Relationship (SAR) Studies. J. Med. Chem. 2017.

80. ElSohly, M. A.; Radwan, M. M.; Gul, W.; Chandra, S.; Galal, A. Phytochemistry of Cannabis sativa L. Prog. Chem. Org. Nat. Prod. 2017, 103, 1-36.

81. Shire, D.; Calandra, B.; Bouaboula, M.; Barth, F.; Rinaldi-Carmona, M.; Casellas, P.; Ferrara, P. Cannabinoid receptor interactions with the antagonists SR 141716A and SR 144528. Life Sci. 1999, $65(6-7), 627-35$.

82. Barth, F.; Rinaldi-Carmona, M. The development of cannabinoid antagonists. Curr. Med. Chem. 1999, 6 (8), 745-55.

83. Rinaldi-Carmona, M.; Barth, F.; Heaulme, M.; Shire, D.; Calandra, B.; Congy, C.; Martinez, S.; Maruani, J.; Neliat, G.; Caput, D.; et al. SR141716A, a potent and selective antagonist of the brain cannabinoid receptor. FEBS Lett 1994, 350 (2-3), 240-4.

84. Bifulco, M.; Grimaldi, C.; Gazzerro, P.; Pisanti, S.; Santoro, A. Rimonabant: just an antiobesity drug? Current evidence on its pleiotropic effects. Mol. Pharmacol. 2007, 71 (6), 1445-56.

85. Pertwee, R.; Griffin, G.; Fernando, S.; Li, X.; Hill, A.; Makriyannis, A. AM630, a competitive cannabinoid receptor antagonist. Life Sci. 1995, 56 (23-24), 1949-55.

86. Lunn, C. A.; Reich, E. P.; Fine, J. S.; Lavey, B.; Kozlowski, J. A.; Hipkin, R. W.; Lundell, D. J.; Bober, L. Biology and therapeutic potential of cannabinoid CB2 receptor inverse agonists. $B r . J$. Pharmacol. 2008, 153 (2), 226-39.

87. Manera, C.; Arena, C.; Chicca, A. Synthetic Cannabinoid Receptor Agonists and Antagonists: Implication in CNS Disorders. Recent Pat. CNS Drug Discov. 2016, 10 (2), 142-156.

88. Fong, T. M.; Heymsfield, S. B. Cannabinoid-1 receptor inverse agonists: current understanding of mechanism of action and unanswered questions. Int. J. Obes. (Lond) 2009, 33 (9), 947-55.

89. Morales, P.; Hernandez-Folgado, L.; Goya, P.; Jagerovic, N. Cannabinoid receptor 2 (CB2) agonists and antagonists: a patent update. Expert. Opin. Ther. Pat. 2016, 26 (7), 843-56. 
90. Sharma, M. K.; Murumkar, P. R.; Kanhed, A. M.; Giridhar, R.; Yadav, M. R. Prospective therapeutic agents for obesity: molecular modification approaches of centrally and peripherally acting selective cannabinoid 1 receptor antagonists. Eur. J. Med. Chem. 2014, 79, 298-339.

91. Sharma, M. K.; Murumkar, P. R.; Barmade, M. A.; Giridhar, R.; Yadav, M. R. A comprehensive patents review on cannabinoid 1 receptor antagonists as antiobesity agents. Expert Opin. Ther. Pat. 2015, 25 (10), 1093-116.

92. Elsohly, M. A.; Slade, D. Chemical constituents of marijuana: the complex mixture of natural cannabinoids. Life Sci. 2005, 78 (5), 539-48.

93. Hill, A. J.; Williams, C. M.; Whalley, B. J.; Stephens, G. J. Phytocannabinoids as novel therapeutic agents in CNS disorders. Pharmacol. Ther. 2012, 133 (1), 79-97.

94. Iwamura, H.; Suzuki, H.; Ueda, Y.; Kaya, T.; Inaba, T. In vitro and in vivo pharmacological characterization of JTE-907, a novel selective ligand for cannabinoid CB2 receptor. J. Pharmacol. Exp. Ther. 2001, 296 (2), 420-5.

95. Thomas, A.; Stevenson, L. A.; Wease, K. N.; Price, M. R.; Baillie, G.; Ross, R. A.; Pertwee, R. G. Evidence that the plant cannabinoid Delta(9)-tetrahydrocannabivarin is a cannabinoid $\mathrm{CB}(1)$ and $\mathrm{CB}(2)$ receptor antagonist. Br. J. Pharmacol. 2005, 146 (7), 917-26.

96. Mechoulam, R.; Peters, M.; Murillo-Rodriguez, E.; Hanus, L. O. Cannabidiol--recent advances. Chem. Biodivers. 2007, 4 (8), 1678-92.

97. Thomas, A.; Baillie, G. L.; Phillips, A. M.; Razdan, R. K.; Ross, R. A.; Pertwee, R. G. Cannabidiol displays unexpectedly high potency as an antagonist of CB1 and CB2 receptor agonists in vitro. Br. J. Pharmacol. 2007, 150 (5), 613-23.

98. Pertwee, R. G. The diverse CB1 and CB2 receptor pharmacology of three plant cannabinoids: delta9-tetrahydrocannabinol, cannabidiol and delta9-tetrahydrocannabivarin. Br. J. Pharmacol. 2008, $153(2), 199-215$.

99. Gertsch, J.; Leonti, M.; Raduner, S.; Racz, I.; Chen, J. Z.; Xie, X. Q.; Altmann, K. H.; Karsak, M.; Zimmer, A. Beta-caryophyllene is a dietary cannabinoid. Proc. Natl. Acad. Sci. U S A 2008, 105 (26), 9099-104.

100. Weissman, A.; Milne, G. M.; Melvin, L. S. Jr. Cannabimimetic activity from CP-47,497, a derivative of 3-phenylcyclohexanol. J. Pharmacol. Exp. Ther. 1982, 223 (2), 516-23.

101. Little, P. J.; Compton, D. R.; Johnson, M. R.; Melvin, L. S.; Martin, B. R. Pharmacology and stereoselectivity of structurally novel cannabinoids in mice. J. Pharmacol. Exp. Ther. 1988, 247 (3), 1046-51.

102. Herkenham, M.; Lynn, A. B.; Johnson, M. R.; Melvin, L. S.; de Costa, B. R.; Rice, K. C. Characterization and localization of cannabinoid receptors in rat brain: a quantitative in vitro autoradiographic study. J. Neurosci. 1991, 11 (2), 563-83.

103. Gareau, Y. D. Claude; Gallant, Michel; Rochette, Chantal; Sawyer, Nicole; Slipetz, Deborah M.; Tremblay, Nathalie; Weech, Philip K.; Metters, Kathleen M.; Labelle, Marc, Structure activity relationships of tetrahydrocanabinol analogs on human cannabinoid receptors. Bioorg. Med. Chem. Lett. 1996, 6 (2), 189-94.

104. Little, P. J.; Compton, D. R.; Mechoulam, R.; Martin, B. R. Stereochemical effects of 11-OHdelta 8-THC-dimethylheptyl in mice and dogs. Pharmacol. Biochem. Behav. 1989, 32 (3), 661-6.

105. Jarbe, T. U.; Hiltunen, A. J.; Mechoulam, R. Stereospecificity of the discriminative stimulus functions of the dimethylheptyl homologs of 11-hydroxy-delta 8-tetrahydrocannabinol in rats and pigeons. J. Pharmacol. Exp. Ther. 1989, 250 (3), 1000-5.

106. Govaerts, S. J.; Hermans, E.; Lambert, D. M. Comparison of cannabinoid ligands affinities and efficacies in murine tissues and in transfected cells expressing human recombinant cannabinoid receptors. Eur. J. Pharm. Sci. 2004, 23 (3), 233-43.

107. Huffman, J. W.; Yu, S.; Showalter, V.; Abood, M. E.; Wiley, J. L.; Compton, D. R.; Martin, B. R.; Bramblett, R. D.; Reggio, P. H. Synthesis and pharmacology of a very potent cannabinoid lacking a phenolic hydroxyl with high affinity for the CB2 receptor. J. Med. Chem. 1996, 39 (20), 3875-7.

108. Huffman, J. W.; Zengin, G.; Wu, M. J.; Lu, J.; Hynd, G.; Bushell, K.; Thompson, A. L.; Bushell, S.; Tartal, C.; Hurst, D. P.; Reggio, P. H.; Selley, D. E.; Cassidy, M. P.; Wiley, J. L.; Martin, B. R. Structure-activity relationships for 1-alkyl-3-(1-naphthoyl)indoles at the cannabinoid CB(1) and 
$\mathrm{CB}(2)$ receptors: steric and electronic effects of naphthoyl substituents. New highly selective $\mathrm{CB}(2)$ receptor agonists. Bioorg. Med. Chem. 2005, 13 (1), 89-112.

109. Hanus, L.; Breuer, A.; Tchilibon, S.; Shiloah, S.; Goldenberg, D.; Horowitz, M.; Pertwee, R. G.; Ross, R. A.; Mechoulam, R.; Fride, E. HU-308: a specific agonist for CB(2), a peripheral cannabinoid receptor. Proc. Natl. Acad. Sci. U S A 1999, 96 (25), 14228-33.

110. Khanolkar, A. D.; Lu, D.; Ibrahim, M.; Duclos, R. I. Jr.; Thakur, G. A.; Malan, T. P. Jr.; Porreca, F.; Veerappan, V.; Tian, X.; George, C.; Parrish, D. A.; Papahatjis, D. P.; Makriyannis, A. Cannabilactones: a novel class of CB2 selective agonists with peripheral analgesic activity. J. Med. Chem. 2007, 50 (26), 6493-500.

111. Wiley, J. L.; Beletskaya, I. D.; Ng, E. W.; Dai, Z.; Crocker, P. J.; Mahadevan, A.; Razdan, R. K.; Martin, B. R. Resorcinol derivatives: a novel template for the development of cannabinoid $\mathrm{CB}(1) / \mathrm{CB}(2)$ and $\mathrm{CB}(2)$-selective agonists. J. Pharmacol. Exp. Ther. 2002, 301 (2), 679-89.

112. Worm, K.; Zhou, Q. J.; Stabley, G. J.; DeHaven, R. N.; Dolle, R. E. Biaryl cannabinoid mimetics--synthesis and structure-activity relationship. Bioorg. Med. Chem. Lett. 2007, 17 (13), 36526.

113. Horvath, B.; Magid, L.; Mukhopadhyay, P.; Batkai, S.; Rajesh, M.; Park, O.; Tanchian, G.; Gao, R. Y.; Goodfellow, C. E.; Glass, M.; Mechoulam, R.; Pacher, P. A new cannabinoid CB2 receptor agonist HU-910 attenuates oxidative stress, inflammation and cell death associated with hepatic ischaemia/reperfusion injury. Br. J. Pharmacol. 2012, 165 (8), 2462-78.

114. Smoum, R.; Baraghithy, S.; Chourasia, M.; Breuer, A.; Mussai, N.; Attar-Namdar, M.; Kogan, N. M.; Raphael, B.; Bolognini, D.; Cascio, M. G.; Marini, P.; Pertwee, R. G.; Shurki, A.; Mechoulam, R.; Bab, I. CB2 cannabinoid receptor agonist enantiomers HU-433 and HU-308: An inverse relationship between binding affinity and biological potency. Proc. Natl. Acad. Sci. U S A 2015, 112 (28), 8774-9.

115. Ohta, H.; Ishizaka, T.; Tatsuzuki, M.; Yoshinaga, M.; Iida, I.; Yamaguchi, T.; Tomishima, Y.; Futaki, N.; Toda, Y.; Saito, S. Imine derivatives as new potent and selective CB2 cannabinoid receptor agonists with an analgesic action. Bioorg. Med. Chem. 2008, 16 (3), 1111-24.

116. Yang, S. W.; Smotryski, J.; Matasi, J.; Ho, G.; Tulshian, D.; Greenlee, W. J.; Brusa, R.; Beltramo, M.; Cox, K. Structure-activity relationships of 2,4-diphenyl-1H-imidazole analogs as CB2 receptor agonists for the treatment of chronic pain. Bioorg. Med. Chem. Lett. 2011, 21 (1), 182-5.

117. Tourteau, A.; Andrzejak, V.; Body-Malapel, M.; Lemaire, L.; Lemoine, A.; Mansouri, R.; Djouina, M.; Renault, N.; El Bakali, J.; Desreumaux, P.; Muccioli, G. G.; Lambert, D. M.; Chavatte, P.; Rigo, B.; Leleu-Chavain, N.; Millet, R. 3-Carboxamido-5-aryl-isoxazoles as new CB2 agonists for the treatment of colitis. Bioorg. Med. Chem. 2013, 21 (17), 5383-94.

118. Ohta, H.; Ishizaka, T.; Yoshinaga, M.; Morita, A.; Tomishima, Y.; Toda, Y.; Saito, S. Sulfonamide derivatives as new potent and selective CB2 cannabinoid receptor agonists. Bioorg. Med. Chem. Lett. 2007, 17 (18), 5133-5.

119. Ohta, H.; Ishizaka, T.; Tatsuzuki, M.; Yoshinaga, M.; Iida, I.; Tomishima, Y.; Toda, Y.; Saito, S. N-Alkylidenearylcarboxamides as new potent and selective $\mathrm{CB}(2)$ cannabinoid receptor agonists with good oral bioavailability. Bioorg. Med. Chem. Lett. 2007, 17 (22), 6299-304.

120. Cheng, Y.; Albrecht, B. K.; Brown, J.; Buchanan, J. L.; Buckner, W. H.; DiMauro, E. F.; Emkey, R.; Fremeau, R. T. Jr.; Harmange, J. C.; Hoffman, B. J.; Huang, L.; Huang, M.; Lee, J. H.; Lin, F. F.; Martin, M. W.; Nguyen, H. Q.; Patel, V. F.; Tomlinson, S. A.; White, R. D.; Xia, X.; Hitchcock, S. A. Discovery and optimization of a novel series of $\mathrm{N}$-arylamide oxadiazoles as potent, highly selective and orally bioavailable cannabinoid receptor 2 (CB2) agonists. J. Med. Chem. 2008, 51 (16), 5019-34.

121. DiMauro, E. F.; Buchanan, J. L.; Cheng, A.; Emkey, R.; Hitchcock, S. A.; Huang, L.; Huang, M. Y.; Janosky, B.; Lee, J. H.; Li, X.; Martin, M. W.; Tomlinson, S. A.; White, R. D.; Zheng, X. M.; Patel, V. F.; Fremeau, R. T. Jr. Structural modifications of N-arylamide oxadiazoles: Identification of $\mathrm{N}$-arylpiperidine oxadiazoles as potent and selective agonists of CB2. Bioorg. Med. Chem. Lett. 2008, $18(15), 4267-74$.

122. Han, S.; Thoresen, L.; Zhu, X.; Narayanan, S.; Jung, J. K.; Strah-Pleynet, S.; Decaire, M.; Choi, K.; Xiong, Y.; Yue, D.; Semple, G.; Thatte, J.; Solomon, M.; Fu, L.; Whelan, K.; Al-Shamma, H.; Gatlin, J.; Chen, R.; Dang, H.; Pride, C.; Gaidarov, I.; Unett, D. J.; Behan, D. P.; Sadeque, A.; Usmani, K. A.; Chen, C.; Edwards, J.; Morgan, M.; Jones, R. M. Discovery of 1a,2,5,5a-tetrahydro- 
1H-2,3-diaza-cyclopropa[a]pentalen-4-carboxamides as potent and selective CB2 receptor agonists. Bioorg. Med. Chem. Lett. 2015, 25 (2), 322-6.

123. Eatherton, A. J. Giblin, G.M.P; Green, R.H; Mitchell, W.L.; Naylor, A.; Rawlings, D.A.; Slingsby, B.P.; Brian, P.; Whittington, A.R. Preparation of aminopyrimidinecarboxamides and their use as CB2-type cannabinoid receptor modulators. PCT Int. Appl. WO 2004018433 A1 4 Mar 2004.

124. Giblin, G. M.; O'Shaughnessy, C. T.; Naylor, A.; Mitchell, W. L.; Eatherton, A. J.; Slingsby, B. P.; Rawlings, D. A.; Goldsmith, P.; Brown, A. J.; Haslam, C. P.; Clayton, N. M.; Wilson, A. W.; Chessell, I. P.; Wittington, A. R.; Green, R. Discovery of 2-[(2,4-dichlorophenyl)amino]-N[(tetrahydro- 2H-pyran-4-yl)methyl]-4-(trifluoromethyl)- 5-pyrimidinecarboxamide, a selective CB2 receptor agonist for the treatment of inflammatory pain. J. Med. Chem. 2007, 50 (11), 2597-600.

125. Mitchell, W. L.; Giblin, G. M.; Naylor, A.; Eatherton, A. J.; Slingsby, B. P.; Rawlings, A. D.; Jandu, K. S.; Haslam, C. P.; Brown, A. J.; Goldsmith, P.; Clayton, N. M.; Wilson, A. W.; Chessell, I. P.; Green, R. H.; Whittington, A. R.; Wall, I. D. Pyridine-3-carboxamides as novel CB(2) agonists for analgesia. Bioorg. Med. Chem. Lett. 2009, 19 (1), 259-63.

126. Zindell, R.; Riether, D.; Bosanac, T.; Berry, A.; Gemkow, M. J.; Ebneth, A.; Lobbe, S.; Raymond, E. L.; Thome, D.; Shih, D. T.; Thomson, D. Morpholine containing CB2 selective agonists. Bioorg. Med. Chem. Lett. 2009, 19 (6), 1604-9.

127. Mukhopadhyay, P.; Baggelaar, M.; Erdelyi, K.; Cao, Z.; Cinar, R.; Fezza, F.; IgnatowskaJanlowska, B.; Wilkerson, J.; van Gils, N.; Hansen, T.; Ruben, M.; Soethoudt, M.; Heitman, L.; Kunos, G.; Maccarrone, M.; Lichtman, A.; Pacher, P.; Van der Stelt, M. The novel, orally available and peripherally restricted selective cannabinoid CB2 receptor agonist LEI-101 prevents cisplatininduced nephrotoxicity. Br. J. Pharmacol. 2016, 173 (3), 446-58.

128. Odan, M.; Ishizuka, N.; Hiramatsu, Y.; Inagaki, M.; Hashizume, H.; Fujii, Y.; Mitsumori, S.; Morioka, Y.; Soga, M.; Deguchi, M.; Yasui, K.; Arimura, A. Discovery of S-444823, a potent CB1/CB2 dual agonist as an antipruritic agent. Bioorg. Med. Chem. Lett. 2012, 22 (8), 2898-901.

129. El Bakali, J.; Muccioli, G. G.; Renault, N.; Pradal, D.; Body-Malapel, M.; Djouina, M.; Hamtiaux, L.; Andrzejak, V.; Desreumaux, P.; Chavatte, P.; Lambert, D. M.; Millet, R. 4-Oxo-1,4dihydropyridines as selective CB2 cannabinoid receptor ligands: structural insights into the design of a novel inverse agonist series. J. Med. Chem. 2010, 53 (22), 7918-31.

130. Gleave, R. J.; Beswick, P. J.; Brown, A. J.; Giblin, G. M.; Haslam, C. P.; Livermore, D.; Moses, A.; Nicholson, N. H.; Page, L. W.; Slingsby, B.; Swarbrick, M. E. 2-Amino-5-aryl-pyridines as selective CB2 agonists: synthesis and investigation of structure-activity relationships. Bioorg. Med. Chem. Lett. 2009, 19 (23), 6578-81.

131. Gleave, R. J.; Beswick, P. J.; Brown, A. J.; Giblin, G. M.; Goldsmith, P.; Haslam, C. P.; Mitchell, W. L.; Nicholson, N. H.; Page, L. W.; Patel, S.; Roomans, S.; Slingsby, B. P.; Swarbrick, M. E. Synthesis and evaluation of 3-amino-6-aryl-pyridazines as selective $\mathrm{CB}(2)$ agonists for the treatment of inflammatory pain. Bioorg. Med. Chem. Lett. 2010, 20 (2), 465-8.

132. Qian, H. Y.; Wang, Z. L.; Xie, X. Y.; Pan, Y. L.; Li, G. J.; Xie, X.; Chen, J. Z. Developing pyridazine-3-carboxamides to be CB2 agonists: The design, synthesis, structure-activity relationships and docking studies. Eur. J. Med. Chem. 2017, 137, 598-611.

133. Kai, H.; Morioka, Y.; Murashi, T.; Morita, K.; Shinonome, S.; Nakazato, H.; Kawamoto, K.; Hanasaki, K.; Takahashi, F.; Mihara, S.; Arai, T.; Abe, K.; Okabe, H.; Baba, T.; Yoshikawa, T.; Takenaka, H. 2-Arylimino-5,6-dihydro-4H-1,3-thiazines as a new class of cannabinoid receptor agonists. Part 1: discovery of CB2 receptor selective compounds. Bioorg. Med. Chem. Lett. 2007, 17 (14), 4030-4.

134. Kai, H.; Morioka, Y.; Tomida, M.; Takahashi, T.; Hattori, M.; Hanasaki, K.; Koike, K.; Chiba, H.; Shinohara, S.; Kanemasa, T.; Iwamoto, Y.; Takahashi, K.; Yamaguchi, Y.; Baba, T.; Yoshikawa, T.; Takenaka, H. 2-Arylimino-5,6-dihydro-4H-1,3-thiazines as a new class of cannabinoid receptor agonists. Part 2: orally bioavailable compounds. Bioorg. Med. Chem. Lett. 2007, 17 (14), 3925-9.

135. Yrjola, S.; Kalliokoski, T.; Laitinen, T.; Poso, A.; Parkkari, T.; Nevalainen, T. Discovery of novel cannabinoid receptor ligands by a virtual screening approach: further development of 2,4,6trisubstituted 1,3,5-triazines as CB2 agonists. Eur. J. Pharm. Sci. 2013, 48 (1-2), 9-20.

136. Yrjola, S.; Sarparanta, M.; Airaksinen, A. J.; Hytti, M.; Kauppinen, A.; Pasonen-Seppanen, S.; Adinolfi, B.; Nieri, P.; Manera, C.; Keinanen, O.; Poso, A.; Nevalainen, T. J.; Parkkari, T. Synthesis, 
in vitro and in vivo evaluation of 1,3,5-triazines as cannabinoid CB2 receptor agonists. Eur. J. Pharm. Sci. 2015, 67, 85-96.

137. Bell, M. R.; D'Ambra, T. E.; Kumar, V.; Eissenstat, M. A.; Herrmann, J. L. Jr.; Wetzel, J. R.; Rosi, D.; Philion, R. E.; Daum, S. J.; Hlasta, D. J.; et al. Antinociceptive (aminoalkyl)indoles. J. Med. Chem. 1991, 34 (3), 1099-110.

138. D'Ambra, T. E.; Estep, K. G.; Bell, M. R.; Eissenstat, M. A.; Josef, K. A.; Ward, S. J.; Haycock, D. A.; Baizman, E. R.; Casiano, F. M.; Beglin, N. C.; et al. Conformationally restrained analogues of pravadoline: nanomolar potent, enantioselective, (aminoalkyl)indole agonists of the cannabinoid receptor. J. Med. Chem. 1992, 35 (1), 124-35.

139. Marriott, K. S.; Huffman, J. W. Recent advances in the development of selective ligands for the cannabinoid CB(2) receptor. Curr. Top. Med. Chem. 2008, 8 (3), 187-204.

140. Manera, C.; Tuccinardi, T.; Martinelli, A. Indoles and related compounds as cannabinoid ligands. Mini Rev. Med. Chem. 2008, 8 (4), 370-87.

141. Huffman, J. W.; Padgett, L. W. Recent developments in the medicinal chemistry of cannabimimetic indoles, pyrroles and indenes. Curr. Med. Chem. 2005, 12 (12), 1395-411.

142. Poso, A.; Huffman, J. W. Targeting the cannabinoid CB2 receptor: modelling and structural determinants of CB2 selective ligands. Br. J. Pharmacol. 2008, 153 (2), 335-46.

143. Showalter, V. M.; Compton, D. R.; Martin, B. R.; Abood, M. E. Evaluation of binding in a transfected cell line expressing a peripheral cannabinoid receptor (CB2): identification of cannabinoid receptor subtype selective ligands. J. Pharmacol. Exp. Ther. 1996, 278 (3), 989-99.

144. Gallant, M. D. Claude; Gareau, Yves; Guay, Daniel; Leblanc, Yves; Prasit, Petipibbon; Rochette, Chantal; Sawyer, Nicole; Slipetz, Deborah M.; et al. New class of potent ligands for the human peripheral cannabinoid receptor. Bioorg. Med. Chem. Lett. 1996, 6 (19), 2263-2268.

145. Valenzano, K. J.; Tafesse, L.; Lee, G.; Harrison, J. E.; Boulet, J. M.; Gottshall, S. L.; Mark, L.; Pearson, M. S.; Miller, W.; Shan, S.; Rabadi, L.; Rotshteyn, Y.; Chaffer, S. M.; Turchin, P. I.; Elsemore, D. A.; Toth, M.; Koetzner, L.; Whiteside, G. T. Pharmacological and pharmacokinetic characterization of the cannabinoid receptor 2 agonist, GW405833, utilizing rodent models of acute and chronic pain, anxiety, ataxia and catalepsy. Neuropharmacology 2005, 48 (5), 658-72.

146. Bingham, B.; Jones, P. G.; Uveges, A. J.; Kotnis, S.; Lu, P.; Smith, V. A.; Sun, S. C.; Resnick, L.; Chlenov, M.; He, Y.; Strassle, B. W.; Cummons, T. A.; Piesla, M. J.; Harrison, J. E.; Whiteside, G. T.; Kennedy, J. D. Species-specific in vitro pharmacological effects of the cannabinoid receptor 2 (CB2) selective ligand AM1241 and its resolved enantiomers. Br. J. Pharmacol. 2007, 151 (7), 106170.

147. Malan, T. P. Jr.; Ibrahim, M. M.; Deng, H.; Liu, Q.; Mata, H. P.; Vanderah, T.; Porreca, F.; Makriyannis, A. CB2 cannabinoid receptor-mediated peripheral antinociception. Pain 2001, 93 (3), $239-45$.

148. Ibrahim, M. M.; Deng, H.; Zvonok, A.; Cockayne, D. A.; Kwan, J.; Mata, H. P.; Vanderah, T. W.; Lai, J.; Porreca, F.; Makriyannis, A.; Malan, T. P. Jr. Activation of CB2 cannabinoid receptors by AM1241 inhibits experimental neuropathic pain: Pain inhibition by receptors not present in the CNS. Proc. Natl. Acad. Sci. US A 2003, 100 (18), 10529-33.

149. Hynes, J. Jr.; Leftheris, K.; Wu, H.; Pandit, C.; Chen, P.; Norris, D. J.; Chen, B. C.; Zhao, R.; Kiener, P. A.; Chen, X.; Turk, L. A.; Patil-Koota, V.; Gillooly, K. M.; Shuster, D. J.; McIntyre, K. W. C-3 Amido-indole cannabinoid receptor modulators. Bioorg. Med. Chem. Lett. 2002, 12 (17), 2399402 .

150. Yao, B. B.; Hsieh, G. C.; Frost, J. M.; Fan, Y.; Garrison, T. R.; Daza, A. V.; Grayson, G. K.; Zhu, C. Z.; Pai, M.; Chandran, P.; Salyers, A. K.; Wensink, E. J.; Honore, P.; Sullivan, J. P.; Dart, M. J.; Meyer, M. D. In vitro and in vivo characterization of A-796260: a selective cannabinoid CB2 receptor agonist exhibiting analgesic activity in rodent pain models. Br. J. Pharmacol. 2008, 153 (2), 390-401.

151. Frost, J. M.; Dart, M. J.; Tietje, K. R.; Garrison, T. R.; Grayson, G. K.; Daza, A. V.; ElKouhen, O. F.; Miller, L. N.; Li, L.; Yao, B. B.; Hsieh, G. C.; Pai, M.; Zhu, C. Z.; Chandran, P.; Meyer, M. D. Indol-3-yl-tetramethylcyclopropyl ketones: effects of indole ring substitution on CB2 cannabinoid receptor activity. J. Med. Chem. 2008, 51 (6), 1904-12. 
152. Verbist, B. M.; De Cleyn, M. A.; Surkyn, M.; Fraiponts, E.; Aerssens, J.; Nijsen, M. J.; Gijsen, H. J. 5-Sulfonyl-benzimidazoles as selective CB2 agonists. Bioorg. Med. Chem. Lett. 2008, 18 (8), 2574-9.

153. Page, D.; Balaux, E.; Boisvert, L.; Liu, Z.; Milburn, C.; Tremblay, M.; Wei, Z.; Woo, S.; Luo, X.; Cheng, Y. X.; Yang, H.; Srivastava, S.; Zhou, F.; Brown, W.; Tomaszewski, M.; Walpole, C.; Hodzic, L.; St-Onge, S.; Godbout, C.; Salois, D.; Payza, K. Novel benzimidazole derivatives as selective CB2 agonists. Bioorg. Med. Chem. Lett. 2008, 18 (13), 3695-700.

154. Ryckmans, T.; Edwards, M. P.; Horne, V. A.; Correia, A. M.; Owen, D. R.; Thompson, L. R.; Tran, I.; Tutt, M. F.; Young, T. Rapid assessment of a novel series of selective CB(2) agonists using parallel synthesis protocols: A Lipophilic Efficiency (LipE) analysis. Bioorg. Med. Chem. Lett. 2009, 19 (15), 4406-9.

155. Watson, C.; Owen, D. R.; Harding, D.; Kon, I. K.; Lewis, M. L.; Mason, H. J.; Matsumizu, M.; Mukaiyama, T.; Rodriguez-Lens, M.; Shima, A.; Takeuchi, M.; Tran, I.; Young, T. Optimisation of a novel series of selective CNS penetrant CB(2) agonists. Bioorg. Med. Chem. Lett. 2011, 21 (14), 4284-7.

156. Gijsen, H. J.; De Cleyn, M. A.; Surkyn, M.; Van Lommen, G. R.; Verbist, B. M.; Nijsen, M. J.; Meert, T.; Wauwe, J. V.; Aerssens, J. 5-sulfonyl-benzimidazoles as selective CB2 agonists-part 2. Bioorg. Med. Chem. Lett. 2012, 22 (1), 547-52.

157. Nanda, K. K.; Henze, D. A.; Della Penna, K.; Desai, R.; Leitl, M.; Lemaire, W.; White, R. B.; Yeh, S.; Brouillette, J. N.; Hartman, G. D.; Bilodeau, M. T.; Trotter, B. W. Benzimidazole CB2 agonists: design, synthesis and SAR. Bioorg. Med. Chem. Lett. 2014, 24 (4), 1218-21.

158. Iwata, Y.; Ando, K.; Taniguchi, K.; Koba, N.; Sugiura, A.; Sudo, M. Identification of a highly potent and selective CB2 agonist, RQ-00202730, for the treatment of irritable bowel syndrome. Bioorg. Med. Chem. Lett. 2015, 25 (2), 236-40.

159. Aghazadeh Tabrizi, M.; Baraldi, P. G.; Saponaro, G.; Moorman, A. R.; Romagnoli, R.; Preti, D.; Baraldi, S.; Corciulo, C.; Vincenzi, F.; Borea, P. A.; Varani, K. Design, synthesis, and pharmacological properties of new heteroarylpyridine/heteroarylpyrimidine derivatives as $\mathrm{CB}(2)$ cannabinoid receptor partial agonists. J. Med. Chem. 2013, 56 (3), 1098-112.

160. Trotter, B. W.; Nanda, K. K.; Burgey, C. S.; Potteiger, C. M.; Deng, J. Z.; Green, A. I.; Hartnett, J. C.; Kett, N. R.; Wu, Z.; Henze, D. A.; Della Penna, K.; Desai, R.; Leitl, M. D.; Lemaire, W.; White, R. B.; Yeh, S.; Urban, M. O.; Kane, S. A.; Hartman, G. D.; Bilodeau, M. T. Imidazopyridine $\mathrm{CB} 2$ agonists: optimization of $\mathrm{CB} 2 / \mathrm{CB} 1$ selectivity and implications for in vivo analgesic efficacy. Bioorg. Med. Chem. Lett. 2011, 21 (8), 2354-8.

161. Hollinshead, S. P.; Astles, P. C.; Chambers, M. G.; Johnson, M. P.; Palmer, J.; Tidwell, M. W. Discovery and optimization of novel purines as potent and selective CB2 agonists. Bioorg. Med. Chem. Lett. 2012, 22 (15), 4962-6.

162. Hollinshead, S. P.; Tidwell, M. W.; Palmer, J.; Guidetti, R.; Sanderson, A.; Johnson, M. P.; Chambers, M. G.; Oskins, J.; Stratford, R.; Astles, P. C. Selective cannabinoid receptor type 2 (CB2) agonists: optimization of a series of purines leading to the identification of a clinical candidate for the treatment of osteoarthritic pain. J. Med. Chem. 2013, 56 (14), 5722-33.

163. Diaz, P.; Phatak, S. S.; Xu, J.; Fronczek, F. R.; Astruc-Diaz, F.; Thompson, C. M.; Cavasotto, C. N.; Naguib, M. 2,3-Dihydro-1-benzofuran derivatives as a series of potent selective cannabinoid receptor 2 agonists: design, synthesis, and binding mode prediction through ligand-steered modeling. ChemMedChem 2009, 4 (10), 1615-29.

164. Manera, C.; Benetti, V.; Castelli, M. P.; Cavallini, T.; Lazzarotti, S.; Pibiri, F.; Saccomanni, G.; Tuccinardi, T.; Vannacci, A.; Martinelli, A.; Ferrarini, P. L. Design, synthesis, and biological evaluation of new 1,8-naphthyridin-4(1H)-on-3-carboxamide and quinolin-4(1H)-on-3-carboxamide derivatives as CB2 selective agonists. J. Med. Chem. 2006, 49 (20), 5947-57.

165. Stern, E.; Muccioli, G. G.; Millet, R.; Goossens, J. F.; Farce, A.; Chavatte, P.; Poupaert, J. H.; Lambert, D. M.; Depreux, P.; Henichart, J. P. Novel 4-oxo-1,4-dihydroquinoline-3-carboxamide derivatives as new CB2 cannabinoid receptors agonists: synthesis, pharmacological properties and molecular modeling. J. Med. Chem. 2006, 49 (1), 70-9.

166. Pasquini, S.; Botta, L.; Semeraro, T.; Mugnaini, C.; Ligresti, A.; Palazzo, E.; Maione, S.; Di Marzo, V.; Corelli, F. Investigations on the 4-quinolone-3-carboxylic acid motif. 2. Synthesis and 
structure-activity relationship of potent and selective cannabinoid-2 receptor agonists endowed with analgesic activity in vivo. J. Med. Chem. 2008, 51 (16), 5075-84.

167. Manley, P. J.; Zartman, A.; Paone, D. V.; Burgey, C. S.; Henze, D. A.; Della Penna, K.; Desai, R.; Leitl, M. D.; Lemaire, W.; White, R. B.; Yeh, S.; Urban, M. O.; Kane, S. A.; Hartman, G. D.; Bilodeau, M. T.; Trotter, B. W. Decahydroquinoline amides as highly selective CB2 agonists: role of selectivity on in vivo efficacy in a rodent model of analgesia. Bioorg. Med. Chem. Lett. 2011, 21 (8), 2359-64.

168. Manera, C.; Cascio, M. G.; Benetti, V.; Allara, M.; Tuccinardi, T.; Martinelli, A.; Saccomanni, G.; Vivoli, E.; Ghelardini, C.; Di Marzo, V.; Ferrarini, P. L. New 1,8-naphthyridine and quinoline derivatives as CB2 selective agonists. Bioorg. Med. Chem. Lett. 2007, 17 (23), 6505-10.

169. Cianchi, F.; Papucci, L.; Schiavone, N.; Lulli, M.; Magnelli, L.; Vinci, M. C.; Messerini, L.; Manera, C.; Ronconi, E.; Romagnani, P.; Donnini, M.; Perigli, G.; Trallori, G.; Tanganelli, E.; Capaccioli, S.; Masini, E. Cannabinoid receptor activation induces apoptosis through tumor necrosis factor alpha-mediated ceramide de novo synthesis in colon cancer cells. Clin. Cancer. Res. 2008, 14 (23), 7691-700.

170. Manera, C.; Saccomanni, G.; Adinolfi, B.; Benetti, V.; Ligresti, A.; Cascio, M. G.; Tuccinardi, T.; Lucchesi, V.; Martinelli, A.; Nieri, P.; Masini, E.; Di Marzo, V.; Ferrarini, P. L. Rational design, synthesis, and pharmacological properties of new 1,8-naphthyridin-2(1H)-on-3-carboxamide derivatives as highly selective cannabinoid-2 receptor agonists. J. Med. Chem. 2009, 52 (12), 3644-51. 171. Lucchesi, V.; Hurst, D. P.; Shore, D. M.; Bertini, S.; Ehrmann, B. M.; Allara, M.; Lawrence, L.; Ligresti, A.; Minutolo, F.; Saccomanni, G.; Sharir, H.; Macchia, M.; Di Marzo, V.; Abood, M. E.; Reggio, P. H.; Manera, C. CB2-selective cannabinoid receptor ligands: synthesis, pharmacological evaluation, and molecular modeling investigation of 1,8-Naphthyridin-2(1H)-one-3-carboxamides. $J$. Med. Chem. 2014, 57 (21), 8777-91.

172. Cheng, Y. X.; Pourashraf, M.; Luo, X.; Srivastava, S.; Walpole, C.; Salois, D.; St-Onge, S.; Payza, K.; Lessard, E.; Yu, X. H.; Tomaszewski, M. J. gamma-Carbolines: a novel class of cannabinoid agonists with high aqueous solubility and restricted CNS penetration. Bioorg. Med. Chem. Lett. 2012, 22 (4), 1619-24.

173. El Bakali, J.; Muccioli, G. G.; Body-Malapel, M.; Djouina, M.; Klupsch, F.; Ghinet, A.; Barczyk, A.; Renault, N.; Chavatte, P.; Desreumaux, P.; Lambert, D. M.; Millet, R. Conformational Restriction Leading to a Selective CB2 Cannabinoid Receptor Agonist Orally Active Against Colitis. ACS Med. Chem. Lett. 2015, 6 (2), 198-203.

174. Gonsiorek, W.; Lunn, C. A.; Fan, X.; Deno, G.; Kozlowski, J.; Hipkin, R. W. Sch35966 is a potent, selective agonist at the peripheral cannabinoid receptor (CB2) in rodents and primates. $B r . J$. Pharmacol. 2007, 151 (8), 1262-71.

175. Baraldi, P. G.; Saponaro, G.; Moorman, A. R.; Romagnoli, R.; Preti, D.; Baraldi, S.; Ruggiero, E.; Varani, K.; Targa, M.; Vincenzi, F.; Borea, P. A.; Aghazadeh Tabrizi, M. 7-Oxo[1,4] oxazino[2,3,4-ij]quinoline-6-carboxamides as selective $\mathrm{CB}(2)$ cannabinoid receptor ligands: structural investigations around a novel class of full agonists. J. Med. Chem. 2012, 55 (14), 6608-23.

176. Vincenzi, F.; Targa, M.; Corciulo, C.; Tabrizi, M. A.; Merighi, S.; Gessi, S.; Saponaro, G.; Baraldi, P. G.; Borea, P. A.; Varani, K. Antinociceptive effects of the selective CB2 agonist MT178 in inflammatory and chronic rodent pain models. Pain 2013, 154 (6), 864-73.

177. Marx, I. E.; DiMauro, E. F.; Cheng, A.; Emkey, R.; Hitchcock, S. A.; Huang, L.; Huang, M. Y.; Human, J.; Lee, J. H.; Li, X.; Martin, M. W.; White, R. D.; Fremeau, R. T. Jr.; Patel, V. F. Discovery of alpha-amidosulfones as potent and selective agonists of CB2: synthesis, SAR, and pharmacokinetic properties. Bioorg. Med. Chem. Lett. 2009, 19 (1), 31-5.

178. Ermann, M.; Riether, D.; Walker, E. R.; Mushi, I. F.; Jenkins, J. E.; Noya-Marino, B.; Brewer, M. L.; Taylor, M. G.; Amouzegh, P.; East, S. P.; Dymock, B. W.; Gemkow, M. J.; Kahrs, A. F.; Ebneth, A.; Lobbe, S.; O'Shea, K.; Shih, D. T.; Thomson, D. Arylsulfonamide CB2 receptor agonists: SAR and optimization of CB2 selectivity. Bioorg. Med. Chem. Lett. 2008, 18 (5), 1725-9.

179. Goodman, A. J.; Ajello, C. W.; Worm, K.; Le Bourdonnec, B.; Savolainen, M. A.; O'Hare, H.; Cassel, J. A.; Stabley, G. J.; Dehaven, R. N.; Labuda, C. J.; Koblish, M.; Little, P. J.; Brogdon, B. L.; Smith, S. A.; Dolle, R. E. CB2 selective sulfamoyl benzamides: optimization of the amide functionality. Bioorg. Med. Chem. Lett. 2009, 19 (2), 309-13. 
180. Riether, D.; Wu, L.; Cirillo, P. F.; Berry, A.; Walker, E. R.; Ermann, M.; Noya-Marino, B.; Jenkins, J. E.; Albaugh, D.; Albrecht, C.; Fisher, M.; Gemkow, M. J.; Grbic, H.; Lobbe, S.; Moller, C.; O'Shea, K.; Sauer, A.; Shih, D. T.; Thomson, D. S. 1,4-Diazepane compounds as potent and selective CB2 agonists: optimization of metabolic stability. Bioorg. Med. Chem. Lett. 2011, 21 (7), 2011-6.

181. Zindell, R.; Walker, E. R.; Scott, J.; Amouzegh, P.; Wu, L.; Ermann, M.; Thomson, D.; Fisher, M. B.; Fullenwider, C. L.; Grbic, H.; Kaplita, P.; Linehan, B.; Patel, M.; Patel, M.; Lobbe, S.; Block, S.; Albrecht, C.; Gemkow, M. J.; Shih, D. T.; Riether, D. Aryl 1,4-diazepane compounds as potent and selective CB2 agonists: optimization of drug-like properties and target independent parameters. Bioorg. Med. Chem. Lett. 2011, 21 (14), 4276-80.

182. Guzior, N.; Wieckowska, A.; Panek, D.; Malawska, B. Recent development of multifunctional agents as potential drug candidates for the treatment of Alzheimer's disease. Curr. Med. Chem. 2015, 22 (3), 373-404.

183. Bajda, M.; Guzior, N.; Ignasik, M.; Malawska, B. Multi-target-directed ligands in Alzheimer's disease treatment. Curr. Med. Chem. 2011, 18 (32), 4949-75.

184. Perez, D. I.; Martinez, A.; Gil, C.; Campillo, N. E. From Bitopic Inhibitors to Multitarget Drugs for the Future Treatment of Alzheimer's Disease. Curr. Med. Chem. 2015, 22 (33), 3789-806.

185. Gonzalez-Naranjo, P.; Perez-Macias, N.; Campillo, N. E.; Perez, C.; Aran, V. J.; Giron, R.; Sanchez-Robles, E.; Martin, M. I.; Gomez-Canas, M.; Garcia-Arencibia, M.; Fernandez-Ruiz, J.; Paez, J. A. Cannabinoid agonists showing BuChE inhibition as potential therapeutic agents for Alzheimer's disease. Eur. J. Med. Chem. 2014, 73, 56-72.

186. Páez, J. A.; Campillo, N. E.; González-Naranjo, P.; Pérez, C.; Pérez-Macias, N.; López de Ceballos, M.; Martín-Requero, A.; Alquezar, C.; Martin Fontelles, M. I.; Girón, R.; Sánchez, E. M.; Romero, J. Nueva familia de derivados carbonílicos de 1-indazolilo con propiedades cannabinoides y/o colinérgicas y/o reguladoras del péptido beta-amiloide. ES2016/070906, PCT1641.1194 (Dic 16, 2016), CSIC, Universidad Rey Juan Carlos, Hospital Universitario Fundación Alcorcón, Spain.

187. Dolles, D.; Nimczick, M.; Scheiner, M.; Ramler, J.; Stadtmuller, P.; Sawatzky, E.; Drakopoulos, A.; Sotriffer, C.; Wittmann, H. J.; Strasser, A.; Decker, M. Aminobenzimidazoles and Structural Isomers as Templates for Dual-Acting Butyrylcholinesterase Inhibitors and hCB2 R Ligands To Combat Neurodegenerative Disorders. Chem.Med.Chem. 2016, 11 (12), 1270-83.

188. WHO, Global action plan on the public health response to dementia 2017-2025. 2016.

189. Claassen, J. A.; Jansen, R. W. Cholinergically mediated augmentation of cerebral perfusion in Alzheimer's disease and related cognitive disorders: the cholinergic-vascular hypothesis. J. Gerontol. A Biol. Sci. Med. Sci. 2006, 61 (3), 267-71.

190. Coulthard, E.; Singh-Curry, V.; Husain, M. Treatment of attention deficits in neurological disorders. Curr. Opin. Neurol. 2006, 19 (6), 613-8.

191. Villarroya, M.; Garcia, A. G.; Marco-Contelles, J.; Lopez, M. G. An update on the pharmacology of galantamine. Expert Opin. Investig. Drugs 2007, 16 (12), 1987-98.

192. Klafki, H. W.; Staufenbiel, M.; Kornhuber, J.; Wiltfang, J. Therapeutic approaches to Alzheimer's disease. Brain 2006, 129 (Pt 11), 2840-55.

193. Thomas, S. J.; Grossberg, G. T. Memantine: a review of studies into its safety and efficacy in treating Alzheimer's disease and other dementias. Clin. Interv. Aging 2009, 4, 367-77.

194. Ferrer, I. Defining Alzheimer as a common age-related neurodegenerative process not inevitably leading to dementia. Prog Neurobiol 2012, 97 (1), 38-51.

195. Aso, E.; Ferrer, I. CB2 Cannabinoid Receptor As Potential Target against Alzheimer's Disease. Front Neurosci. 2016, 10, 243.

196. Di Marzo, V.; Stella, N.; Zimmer, A. Endocannabinoid signalling and the deteriorating brain. Nat. Rev. Neurosci. 2015, 16 (1), 30-42.

197. Cassano, T.; Calcagnini, S.; Pace, L.; De Marco, F.; Romano, A.; Gaetani, S. Cannabinoid Receptor 2 Signaling in Neurodegenerative Disorders: From Pathogenesis to a Promising Therapeutic Target. Front. Neurosci. 2017, 11, 30.

198. Ahmed, A.; van der Marck, M. A.; van den Elsen, G.; Olde Rikkert, M. Cannabinoids in lateonset Alzheimer's disease. Clin. Pharmacol. Ther. 2015, 97 (6), 597-606.

199. Aso, E.; Ferrer, I. Cannabinoids for treatment of Alzheimer's disease: moving toward the clinic. Front. Pharmacol. 2014, 5, 37. 
200. Koppel, J.; Davies, P. Targeting the endocannabinoid system in Alzheimer's disease. $J$. Alzheimers Dis. 2008, 15 (3), 495-504.

201. Ramirez, B. G.; Blazquez, C.; Gomez del Pulgar, T.; Guzman, M.; de Ceballos, M. L. Prevention of Alzheimer's disease pathology by cannabinoids: neuroprotection mediated by blockade of microglial activation. J. Neurosci. 2005, 25 (8), 1904-13.

202. Solas, M.; Francis, P. T.; Franco, R.; Ramirez, M. J. CB2 receptor and amyloid pathology in frontal cortex of Alzheimer's disease patients. Neurobiol. Aging 2013, 34 (3), 805-8.

203. Bedse, G.; Romano, A.; Cianci, S.; Lavecchia, A. M.; Lorenzo, P.; Elphick, M. R.; Laferla, F. M.; Vendemiale, G.; Grillo, C.; Altieri, F.; Cassano, T.; Gaetani, S. Altered expression of the CB1 cannabinoid receptor in the triple transgenic mouse model of Alzheimer's disease. J. Alzheimers Dis. 2014, 40 (3), 701-12.

204. Pacher, P.; Mechoulam, R. Is lipid signaling through cannabinoid 2 receptors part of a protective system? Prog. Lipid. Res. 2011, 50 (2), 193-211.

205. Bisogno, T.; Di Marzo, V. Cannabinoid receptors and endocannabinoids: role in neuroinflammatory and neurodegenerative disorders. CNS Neurol. Disord. Drug Targets 2010, 9 (5), 564-73.

206. Fernandez-Ruiz, J.; Romero, J.; Ramos, J. A. Endocannabinoids and Neurodegenerative Disorders: Parkinson's Disease, Huntington's Chorea, Alzheimer's Disease, and Others. Handb. Exp. Pharmacol. 2015, 231, 233-59.

207. Benito, C.; Tolon, R. M.; Pazos, M. R.; Nunez, E.; Castillo, A. I.; Romero, J. Cannabinoid CB2 receptors in human brain inflammation. Br. J. Pharmacol. 2008, 153 (2), 277-85.

208. Mulder, J.; Zilberter, M.; Pasquare, S. J.; Alpar, A.; Schulte, G.; Ferreira, S. G.; Kofalvi, A.; Martin-Moreno, A. M.; Keimpema, E.; Tanila, H.; Watanabe, M.; Mackie, K.; Hortobagyi, T.; de Ceballos, M. L.; Harkany, T. Molecular reorganization of endocannabinoid signalling in Alzheimer's disease. Brain 2011, 134 (Pt 4), 1041-60.

209. Horti, A. G.; Gao, Y.; Ravert, H. T.; Finley, P.; Valentine, H.; Wong, D. F.; Endres, C. J.; Savonenko, A. V.; Dannals, R. F. Synthesis and biodistribution of [11C]A-836339, a new potential radioligand for PET imaging of cannabinoid type 2 receptors (CB2). Bioorg. Med. Chem. 2010, 18 (14), 5202-7.

210. Esposito, G.; Iuvone, T.; Savani, C.; Scuderi, C.; De Filippis, D.; Papa, M.; Di Marzo, V.; Steardo, L. Opposing control of cannabinoid receptor stimulation on amyloid-beta-induced reactive gliosis: in vitro and in vivo evidence. J. Pharmacol. Exp. Ther. 2007, 322 (3), 1144-52.

211. Haugh, O.; Penman, J.; Irving, A. J.; Campbell, V. A. The Emerging Role of the Cannabinoid Receptor Family in Peripheral and Neuro-immune Interactions. Curr. Drug Targets 2016, 17 (16), 1834-1840.

212. Kaur, R.; Ambwani, S. R.; Singh, S. Endocannabinoid System: A Multi-Facet Therapeutic Target. Curr. Clin. Pharmacol. 2016, 11 (2), 110-7.

213. Ranieri, R.; Laezza, C.; Bifulco, M.; Marasco, D.; Malfitano, A. M. Endocannabinoid System in Neurological Disorders. Recent Pat. CNS Drug Discov. 2016, 10 (2), 90-112.

214. Maccarrone, M.; Maldonado, R.; Casas, M.; Henze, T.; Centonze, D. Cannabinoids therapeutic use: what is our current understanding following the introduction of THC, THC:CBD oromucosal spray and others? Expert. Rev. Clin. Pharmacol. 2017, 10 (4), 443-455.

215. Milton, N. G. Anandamide and noladin ether prevent neurotoxicity of the human amyloid-beta peptide. Neurosci. Lett. 2002, 332 (2), 127-30.

216. Eljaschewitsch, E.; Witting, A.; Mawrin, C.; Lee, T.; Schmidt, P. M.; Wolf, S.; Hoertnagl, H.; Raine, C. S.; Schneider-Stock, R.; Nitsch, R.; Ullrich, O. The endocannabinoid anandamide protects neurons during CNS inflammation by induction of MKP-1 in microglial cells. Neuron 2006, 49 (1), 67-79.

217. Eubanks, L. M.; Rogers, C. J.; Beuscher, A. E. t.; Koob, G. F.; Olson, A. J.; Dickerson, T. J.; Janda, K. D. A molecular link between the active component of marijuana and Alzheimer's disease pathology. Mol. Pharm. 2006, 3 (6), 773-7.

218. Janefjord, E.; Maag, J. L.; Harvey, B. S.; Smid, S. D. Cannabinoid effects on beta amyloid fibril and aggregate formation, neuronal and microglial-activated neurotoxicity in vitro. Cell. Mol. Neurobiol. 2014, 34 (1), 31-42. 
219. Iuvone, T.; Esposito, G.; Esposito, R.; Santamaria, R.; Di Rosa, M.; Izzo, A. A. Neuroprotective effect of cannabidiol, a non-psychoactive component from Cannabis sativa, on betaamyloid-induced toxicity in PC12 cells. J. Neurochem. 2004, 89 (1), 134-41.

220. Ehrhart, J.; Obregon, D.; Mori, T.; Hou, H.; Sun, N.; Bai, Y.; Klein, T.; Fernandez, F.; Tan, J.; Shytle, R. D. Stimulation of cannabinoid receptor 2 (CB2) suppresses microglial activation. $J$. Neuroinflammation 2005, 2, 29.

221. Martin-Moreno, A. M.; Reigada, D.; Ramirez, B. G.; Mechoulam, R.; Innamorato, N.; Cuadrado, A.; de Ceballos, M. L. Cannabidiol and other cannabinoids reduce microglial activation in vitro and in vivo: relevance to Alzheimer's disease. Mol. Pharmacol. 2011, 79 (6), 964-73.

222. Fakhfouri, G.; Ahmadiani, A.; Rahimian, R.; Grolla, A. A.; Moradi, F.; Haeri, A. WIN552122 attenuates amyloid-beta-induced neuroinflammation in rats through activation of cannabinoid receptors and PPAR-gamma pathway. Neuropharmacology 2012, 63 (4), 653-66.

223. Sheng, W. S.; Hu, S.; Min, X.; Cabral, G. A.; Lokensgard, J. R.; Peterson, P. K. Synthetic cannabinoid WIN55,212-2 inhibits generation of inflammatory mediators by IL-1beta-stimulated human astrocytes. Glia 2005, 49 (2), 211-9.

224. Tolon, R. M.; Nunez, E.; Pazos, M. R.; Benito, C.; Castillo, A. I.; Martinez-Orgado, J. A.; Romero, J. The activation of cannabinoid CB2 receptors stimulates in situ and in vitro beta-amyloid removal by human macrophages. Brain Res. 2009, 1283, 148-54.

225. Esposito, G.; De Filippis, D.; Carnuccio, R.; Izzo, A. A.; Iuvone, T. The marijuana component cannabidiol inhibits beta-amyloid-induced tau protein hyperphosphorylation through Wnt/beta-catenin pathway rescue in PC12 cells. J. Mol. Med. (Berl) 2006, 84 (3), 253-8.

226. Cao, C.; Li, Y.; Liu, H.; Bai, G.; Mayl, J.; Lin, X.; Sutherland, K.; Nabar, N.; Cai, J. The potential therapeutic effects of THC on Alzheimer's disease. J Alzheimers Dis 2014, 42 (3), 973-84.

227. Libro, R.; Diomede, F.; Scionti, D.; Piattelli, A.; Grassi, G.; Pollastro, F.; Bramanti, P.; Mazzon, E.; Trubiani, O. Cannabidiol Modulates the Expression of Alzheimer's Disease-Related Genes in Mesenchymal Stem Cells. Int. J. Mol. Sci. 2016, 18 (1).

228. Esposito, G.; De Filippis, D.; Steardo, L.; Scuderi, C.; Savani, C.; Cuomo, V.; Iuvone, T. CB1 receptor selective activation inhibits beta-amyloid-induced iNOS protein expression in C6 cells and subsequently blunts tau protein hyperphosphorylation in co-cultured neurons. Neurosci. Lett. 2006, 404 (3), 342-6.

229. Wang, L.; Liu, B. J.; Cao, Y.; Xu, W. Q.; Sun, D. S.; Li, M. Z.; Shi, F. X.; Li, M.; Tian, Q.; Wang, J. Z.; Zhou, X. W. Deletion of Type-2 Cannabinoid Receptor Induces Alzheimer's DiseaseLike Tau Pathology and Memory Impairment Through AMPK/GSK3beta Pathway. Mol. Neurobiol. 2017.

230. Gonzalez-Naranjo, P.; Campillo, N. E.; Perez, C.; Paez, J. A. Multitarget cannabinoids as novel strategy for Alzheimer disease. Curr. Alzheimer Res. 2013, 10 (3), 229-39.

231. van der Stelt, M.; Mazzola, C.; Esposito, G.; Matias, I.; Petrosino, S.; De Filippis, D.; Micale, V.; Steardo, L.; Drago, F.; Iuvone, T.; Di Marzo, V. Endocannabinoids and beta-amyloid-induced neurotoxicity in vivo: effect of pharmacological elevation of endocannabinoid levels. Cell. Mol. Life Sci. 2006, 63 (12), 1410-24.

232. Chen, R.; Zhang, J.; Fan, N.; Teng, Z. Q.; Wu, Y.; Yang, H.; Tang, Y. P.; Sun, H.; Song, Y.; Chen, C. Delta9-THC-caused synaptic and memory impairments are mediated through COX-2 signaling. Cell 2013, 155 (5), 1154-1165.

233. Aso, E.; Sanchez-Pla, A.; Vegas-Lozano, E.; Maldonado, R.; Ferrer, I. Cannabis-based medicine reduces multiple pathological processes in AbetaPP/PS1 mice. J. Alzheimers Dis. 2015, 43 (3), 977-91.

234. Casarejos, M. J.; Perucho, J.; Gomez, A.; Munoz, M. P.; Fernandez-Estevez, M.; Sagredo, O.; Fernandez Ruiz, J.; Guzman, M.; de Yebenes, J. G.; Mena, M. A. Natural cannabinoids improve dopamine neurotransmission and tau and amyloid pathology in a mouse model of tauopathy. $J$. Alzheimers Dis. 2013, 35 (3), 525-39.

235. Esposito, G.; Scuderi, C.; Savani, C.; Steardo, L. Jr.; De Filippis, D.; Cottone, P.; Iuvone, T.; Cuomo, V.; Steardo, L. Cannabidiol in vivo blunts beta-amyloid induced neuroinflammation by suppressing IL-1beta and iNOS expression. Br. J. Pharmacol. 2007, 151 (8), 1272-9.

236. Martin-Moreno, A. M.; Brera, B.; Spuch, C.; Carro, E.; Garcia-Garcia, L.; Delgado, M.; Pozo, M. A.; Innamorato, N. G.; Cuadrado, A.; de Ceballos, M. L. Prolonged oral cannabinoid 
administration prevents neuroinflammation, lowers beta-amyloid levels and improves cognitive performance in Tg APP 2576 mice. J. Neuroinflammation 2012, 9, 8.

237. Navarro-Dorado, J.; Villalba, N.; Prieto, D.; Brera, B.; Martin-Moreno, A. M.; Tejerina, T.; de Ceballos, M. L. Vascular Dysfunction in a Transgenic Model of Alzheimer's Disease: Effects of CB1R and CB2R Cannabinoid Agonists. Front. Neurosci. 2016, 10, 422.

238. Aso, E.; Juves, S.; Maldonado, R.; Ferrer, I. CB2 cannabinoid receptor agonist ameliorates Alzheimer-like phenotype in AbetaPP/PS1 mice. J. Alzheimers Dis. 2013, 35 (4), 847-58.

239. Chen, B.; Bromley-Brits, K.; He, G.; Cai, F.; Zhang, X.; Song, W. Effect of synthetic cannabinoid HU210 on memory deficits and neuropathology in Alzheimer's disease mouse model. Curr. Alzheimer Res. 2010, 7 (3), 255-61.

240. Cheng, Y.; Dong, Z.; Liu, S. beta-Caryophyllene ameliorates the Alzheimer-like phenotype in APP/PS1 Mice through CB2 receptor activation and the PPARgamma pathway. Pharmacology 2014, $94(1-2), 1-12$.

241. Wu, J.; Bie, B.; Yang, H.; Xu, J. J.; Brown, D. L.; Naguib, M. Activation of the CB2 receptor system reverses amyloid-induced memory deficiency. Neurobiol. Aging. 2013, 34 (3), 791-804.

242. Mendizabal, V. E.; Adler-Graschinsky, E. Cannabinoids as therapeutic agents in cardiovascular disease: a tale of passions and illusions. Br. J. Pharmacol. 2007, 151 (4), 427-40.

243. Kaschina, E. Cannabinoid CB1/CB2 Receptors in the Heart: Expression, Regulation, and Function. In Cannabinoids in Health and Disease, Meccariello, R. a. C. R. Ed. InTech: 2016.

244. Batkai, S.; Pacher, P. Endocannabinoids and cardiac contractile function: pathophysiological implications. Pharmacol. Res. 2009, 60 (2), 99-106.

245. Steffens, S.; Pacher, P. Targeting cannabinoid receptor $\mathrm{CB}(2)$ in cardiovascular disorders: promises and controversies. Br. J. Pharmacol. 2012, 167 (2), 313-23.

246. Zubrzycki, M.; Liebold, A.; Janecka, A.; Zubrzycka, M. A new face of endocannabinoids in pharmacotherapy. Part II: role of endocannabinoids in inflammation-derived cardiovaascular diseases. J. physiol. pharmacol. 2014, 65 (2), 183-91.

247. Mukhopadhyay, P.; Rajesh, M.; Pan, H.; Patel, V.; Mukhopadhyay, B.; Batkai, S.; Gao, B.; Hasko, G.; Pacher, P. Cannabinoid-2 receptor limits inflammation, oxidative/nitrosative stress, and cell death in nephropathy. Free Radic. Biol. Med

2010, 48 (3), 457-67.

248. Mach, F.; Steffens, S. The role of the endocannabinoid system in atherosclerosis. J.neuroendocrinol. 2008, 20 Suppl 1, 53-7.

249. Chiurchiu, V.; Lanuti, M.; Catanzaro, G.; Fezza, F.; Rapino, C.; Maccarrone, M. Detailed characterization of the endocannabinoid system in human macrophages and foam cells, and antiinflammatory role of type-2 cannabinoid receptor. Atherosclerosis 2014, 233 (1), 55-63.

250. McLaren, J. E.; Michael, D. R.; Ashlin, T. G.; Ramji, D. P. Cytokines, macrophage lipid metabolism and foam cells: implications for cardiovascular disease therapy. Prog. Lipid. Res. 2011, 50 (4), 331-47.

251. Libby, P. Inflammation in atherosclerosis. Nature 2002, 420 (6917), 868-74.

252. Libby, P. Inflammation in atherosclerosis. Arterioscler. Thromb. Vasc. Biol. 2012, 32 (9), 2045-51.

253. Swirski, F. K.; Nahrendorf, M. Leukocyte behavior in atherosclerosis, myocardial infarction, and heart failure. Science 2013, 339 (6116), 161-6.

254. Steffens, S.; Veillard, N. R.; Arnaud, C.; Pelli, G.; Burger, F.; Staub, C.; Karsak, M.; Zimmer, A.; Frossard, J. L.; Mach, F. Low dose oral cannabinoid therapy reduces progression of atherosclerosis in mice. Nature 2005, 434 (7034), 782-6.

255. Carbone, F.; Mach, F.; Vuilleumier, N.; Montecucco, F. Cannabinoid receptor type 2 activation in atherosclerosis and acute cardiovascular diseases. Curr. Med. Chem. 2014, 21 (35), 404658.

256. Zhao, Y.; Yuan, Z.; Liu, Y.; Xue, J.; Tian, Y.; Liu, W.; Zhang, W.; Shen, Y.; Xu, W.; Liang, $\mathrm{X}$.; Chen, T. Activation of cannabinoid CB2 receptor ameliorates atherosclerosis associated with suppression of adhesion molecules. J. cardiovasc. pharmacol.2010, 55 (3), 292-8.

257. Willecke, F.; Zeschky, K.; Ortiz Rodriguez, A.; Colberg, C.; Auwarter, V.; Kneisel, S.; Hutter, M.; Lozhkin, A.; Hoppe, N.; Wolf, D.; von zur Muhlen, C.; Moser, M.; Hilgendorf, I.; Bode, C.; 
Zirlik, A. Cannabinoid receptor 2 signaling does not modulate atherogenesis in mice. PLoS One 2011, $6(4)$, e19405.

258. Kalogeris, T.; Baines, C. P.; Krenz, M.; Korthuis, R. J. Cell biology of ischemia/reperfusion injury. Int. rev. cell mol. biol. 2012, 298, 229-317.

259. Wang, P. F.; Jiang, L. S.; Bu, J.; Huang, X. J.; Song, W.; Du, Y. P.; He, B. Cannabinoid-2 receptor activation protects against infarct and ischemia-reperfusion heart injury. J.cardiovasc. pharm. 2012, 59 (4), 301-7.

260. Pacher, P.; Hasko, G. Endocannabinoids and cannabinoid receptors in ischaemia-reperfusion injury and preconditioning. Br. J. Pharmacol. 2008, 153 (2), 252-62.

261. Lepicier, P.; Bibeau-Poirier, A.; Lagneux, C.; Servant, M. J.; Lamontagne, D. Signaling pathways involved in the cardioprotective effects of cannabinoids. J. pharmacol. sci. 2006, 102 (2), $155-66$.

262. Carbone, F.; Nencioni, A.; Mach, F.; Vuilleumier, N.; Montecucco, F. Pathophysiological role of neutrophils in acute myocardial infarction. Thrombosis and haemostasis 2013, 110 (3), 501-14.

263. Lagneux, C.; Lamontagne, D. Involvement of cannabinoids in the cardioprotection induced by lipopolysaccharide. Br. J. Pharmacol. 2001, 132 (4), 793-6.

264. Joyeux, M.; Arnaud, C.; Godin-Ribuot, D.; Demenge, P.; Lamontagne, D.; Ribuot, C. Endocannabinoids are implicated in the infarct size-reducing effect conferred by heat stress preconditioning in isolated rat hearts. Cardiovas. res. 2002, 55 (3), 619-25.

265. Di Filippo, C.; Rossi, F.; Rossi, S.; D'Amico, M. Cannabinoid CB2 receptor activation reduces mouse myocardial ischemia-reperfusion injury: involvement of cytokine/chemokines and PMN. $J$. leuko. biol. 2004, 75 (3), 453-9.

266. Montecucco, F.; Lenglet, S.; Braunersreuther, V.; Burger, F.; Pelli, G.; Bertolotto, M.; Mach, F.; Steffens, S. CB(2) cannabinoid receptor activation is cardioprotective in a mouse model of ischemia/reperfusion. J. mol. cell. cardiol. 2009, 46 (5), 612-20.

267. Defer, N.; Wan, J.; Souktani, R.; Escoubet, B.; Perier, M.; Caramelle, P.; Manin, S.; Deveaux, V.; Bourin, M. C.; Zimmer, A.; Lotersztajn, S.; Pecker, F.; Pavoine, C. The cannabinoid receptor type 2 promotes cardiac myocyte and fibroblast survival and protects against ischemia/reperfusion-induced cardiomyopathy. FASEB J 2009, 23 (7), 2120-30.

268. Li, Q.; Wang, F.; Zhang, Y. M.; Zhou, J. J.; Zhang, Y. Activation of cannabinoid type 2 receptor by JWH133 protects heart against ischemia/reperfusion-induced apoptosis. Cell Physiol. Biochem. 2013, 31 (4-5), 693-702.

269. Wang, Y.; Ma, S.; Wang, Q.; Hu, W.; Wang, D.; Li, X.; Su, T.; Qin, X.; Zhang, X.; Ma, K.; Chen, J.; Xiong, L.; Cao, F. Effects of cannabinoid receptor type 2 on endogenous myocardial regeneration by activating cardiac progenitor cells in mouse infarcted heart. Sci. China-Life sci. 2014, 57 (2), 201-8.

270. Krylatov, A. V.; Ugdyzhekova, D. S.; Bernatskaya, N. A.; Maslov, L. N.; Mekhoulam, R.; Pertwee, R. G.; Stephano, G. B. Activation of type II cannabinoid receptors improves myocardial tolerance to arrhythmogenic effects of coronary occlusion and reperfusion. Bull. Exp. Biol. Med. 2001, $131(6), 523-5$.

271. Hillard, C. J. Role of cannabinoids and endocannabinoids in cerebral ischemia. Curr. Pharm. Des. 2008, 14 (23), 2347-61.

272. Zhang, M.; Martin, B. R.; Adler, M. W.; Razdan, R. K.; Jallo, J. I.; Tuma, R. F. Cannabinoid $\mathrm{CB}(2)$ receptor activation decreases cerebral infarction in a mouse focal ischemia/reperfusion model. J. Cereb. Blood Flow Metab. 2007, 27 (7), 1387-96.

273. Zhang, M.; Martin, B. R.; Adler, M. W.; Razdan, R. K.; Ganea, D.; Tuma, R. F. Modulation of the balance between cannabinoid $\mathrm{CB}(1)$ and $\mathrm{CB}(2)$ receptor activation during cerebral ischemic/reperfusion injury. Neuroscience 2008, 152 (3), 753-60.

274. Murikinati, S.; Juttler, E.; Keinert, T.; Ridder, D. A.; Muhammad, S.; Waibler, Z.; Ledent, C.; Zimmer, A.; Kalinke, U.; Schwaninger, M. Activation of cannabinoid 2 receptors protects against cerebral ischemia by inhibiting neutrophil recruitment. FASEB J 2010, 24 (3), 788-98.

275. Zarruk, J. G.; Fernandez-Lopez, D.; Garcia-Yebenes, I.; Garcia-Gutierrez, M. S.; Vivancos, J.; Nombela, F.; Torres, M.; Burguete, M. C.; Manzanares, J.; Lizasoain, I.; Moro, M. A. Cannabinoid type 2 receptor activation downregulates stroke-induced classic and alternative brain macrophage/microglial activation concomitant to neuroprotection. Stroke 2012, 43 (1), 211-9. 
276. Fernandez-Lopez, D.; Faustino, J.; Derugin, N.; Wendland, M.; Lizasoain, I.; Moro, M. A.; Vexler, Z. S. Reduced infarct size and accumulation of microglia in rats treated with WIN 55,212-2 after neonatal stroke. Neuroscience 2012, 207, 307-15.

277. Bravo-Ferrer, I.; Cuartero, M. I.; Zarruk, J. G.; Pradillo, J. M.; Hurtado, O.; Romera, V. G.; Diaz-Alonso, J.; Garcia-Segura, J. M.; Guzman, M.; Lizasoain, I.; Galve-Roperh, I.; Moro, M. A. Cannabinoid Type-2 Receptor Drives Neurogenesis and Improves Functional Outcome After Stroke. Stroke 2017, 48 (1), 204-212.

278. Zamberletti, E.; Gabaglio, M.; Parolaro, D. The Endocannabinoid System and Autism Spectrum Disorders: Insights from Animal Models. Int. J. Mol. Sci. 2017, 18 (9).

279. Elsabbagh, M.; Divan, G.; Koh, Y. J.; Kim, Y. S.; Kauchali, S.; Marcin, C.; Montiel-Nava, C.; Patel, V.; Paula, C. S.; Wang, C.; Yasamy, M. T.; Fombonne, E. Global prevalence of autism and other pervasive developmental disorders. Autism res. 2012, 5 (3), 160-79.

280. Habib, S. S.; Al-Regaiey, K.; Bashir, S.; Iqbal, M. Role of Endocannabinoids on Neuroinflammation in Autism Spectrum Disorder Prevention. Journal of clinical and diagnostic research : JCDR 2017, 11 (6), CE01-CE03.

281. Turcotte, C.; Blanchet, M. R.; Laviolette, M.; Flamand, N. The CB2 receptor and its role as a regulator of inflammation. Cell Mol. Life Sci. 2016, 73 (23), 4449-4470.

282. Zoppi, S.; Madrigal, J. L.; Caso, J. R.; Garcia-Gutierrez, M. S.; Manzanares, J.; Leza, J. C.; Garcia-Bueno, B. Regulatory role of the cannabinoid CB2 receptor in stress-induced neuroinflammation in mice. Br. J. Pharmacol 2014, 171 (11), 2814-26.

283. Kini, U. N. Physiology of Bone Formation, Remodeling, and Metabolism. In Radionuclide and Hybrid Bone Imaging [Online] Fogelman, I. Gnanasegaran, G.; van der Wall, H. Ed. Springer: 2012.

284. Bab, I.; Ofek, O.; Tam, J.; Rehnelt, J.; Zimmer, A. Endocannabinoids and the regulation of bone metabolism. J. neuroendocrinol. 2008, 20 Suppl 1, 69-74.

285. Tam, J.; Trembovler, V.; Di Marzo, V.; Petrosino, S.; Leo, G.; Alexandrovich, A.; Regev, E.; Casap, N.; Shteyer, A.; Ledent, C.; Karsak, M.; Zimmer, A.; Mechoulam, R.; Yirmiya, R.; Shohami, E.; Bab, I. The cannabinoid $\mathrm{CB} 1$ receptor regulates bone formation by modulating adrenergic signaling. FASEB J 2008, 22 (1), 285-94.

286. Zimmer, A. A collaboration investigating endocannabinoid signalling in brain and bone. $J$. basic clin. physiol. pharmacol. 2016, 27 (3), 229-35.

287. Ofek, O.; Karsak, M.; Leclerc, N.; Fogel, M.; Frenkel, B.; Wright, K.; Tam, J.; Attar-Namdar, M.; Kram, V.; Shohami, E.; Mechoulam, R.; Zimmer, A.; Bab, I. Peripheral cannabinoid receptor, CB2, regulates bone mass. Proc. Natl. Acad. Sci. U S A 2006, 103 (3), 696-701. 
1

2

3

4

5

6

7

8

\author{
Abbreviations \\ 2-AG:2-arachidonoylglycerol; \\ 5-HT2aR: 5-hydroxytryptamine receptor 2a \\ A2aR: adenosine A2a receptor; \\ AChE: acetylcholinesterase; \\ $\mathrm{A} \beta$ : $\beta$-amyloid protein; \\ AChE: acetylcholinesterase; \\ AD: Alzheimer's disease; \\ AEA: anandamide (N-arachidonoylethanolamine); \\ BuChE: butyrylcholinesterase; \\ CBD: cannabidiol; \\ eCS: endocannabinoid system; \\ FAAH: Fatty acid amide hydrolase; \\ GPR18: G protein-coupled receptor 55 \\ hERG: human Ether-à-go-go-Related Gene; \\ HI: hypoxia-ischemia; \\ IFN $\gamma$ : interferon gamma; \\ IL-1 $\beta$ : interleukin-1beta; \\ iNOS: inducible nitric oxide synthase; \\ I/R: ischaemic/reperfusion; \\ LADCA: left anterior descending coronary artery; \\ MAGL: monoacylglycerol lipase; \\ MCAO: middle cerebral artery occlusion; \\ MAPK: Mitogen-activated protein kinase; \\ NADA: N-arachidonoyldopamine; \\ NFкB: nuclear factor kappa-light-chain-enhancer of activated B cells; \\ PPAR- $\gamma$ : peroxisome proliferator activated receptor gamma; \\ SOD1 and SOD2: superoxide dismutase 1 and 2; \\ THC: (-)- $\Delta$ 9-trans-tetrahydrocannabinol; \\ TNF- $\alpha$ : tumor necrosis factor-alpha; \\ TRVP: transient receptor potential vanilloid
}

Tables

Table 1. Binding affinity and selectivity values of selected cannabinoid receptor agonists from $\mathrm{CB} 1$ and $\mathrm{CB} 2$ binding sites ${ }^{\mathrm{a}}$

\begin{tabular}{|l|c|l|c|c|}
\hline & $C B 1 K_{i}(n M)$ & $C B 2 K_{i}(n M)$ & CB1/CB2 & Ref. \\
\hline Endocannabinoids (Fig. 4) & & & & \\
\hline Anandamide & $89 \pm 10$ & $371 \pm 102$ & & {$[143]$} \\
\hline 2AG & $472 \pm 55^{\mathrm{b}}$ & $1400 \pm 172^{\mathrm{b}}$ & & {$[62]$} \\
\hline Noladinether & $21.2 \pm 0.5^{\mathrm{a}}$ & $>3000^{\mathrm{a}}$ & & {$[66]$} \\
\hline Phytocannabinoid (Fig. 1) & & & & \\
\hline$\Delta^{9}$-THC & 53.3 & 75.3 & & {$[61]$} \\
\hline$\Delta^{8}$-THC & $44 \pm 12$ & $44 \pm 17$ & 1.0 & {$[107]$} \\
\hline Cannabinol & 326 & 96.3 & 3.4 & {$[143]$} \\
\hline
\end{tabular}




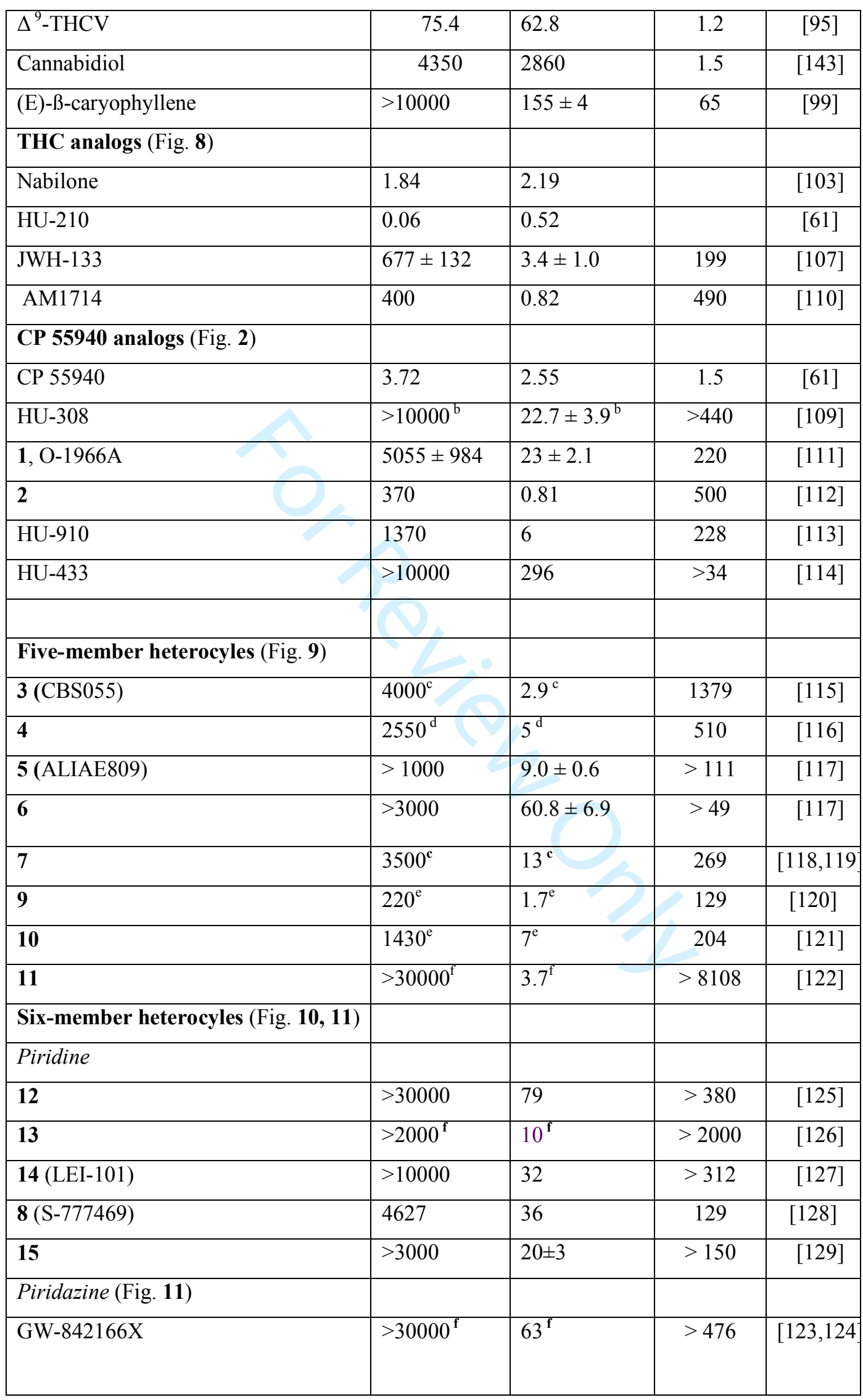




\begin{tabular}{|c|c|c|c|c|}
\hline 16 & $>30000^{f}$ & $79,4^{\mathrm{f}}$ & $>378$ & {$[131]$} \\
\hline 17 & $8000^{f}$ & $10^{f}$ & 800 & {$[131]$} \\
\hline 18 & $>10000$ & $3.665 \pm 0.553$ & $>2729$ & {$[132]$} \\
\hline 19 & $>5000$ & 9 & $>550$ & [133] \\
\hline 20 & $2472^{\mathrm{d}}$ & $0.60^{\mathrm{d}}$ & 4120 & {$[136]$} \\
\hline \multicolumn{5}{|l|}{$[6+5]$ heterocycles } \\
\hline \multicolumn{5}{|l|}{ Indole (Fig. 6) } \\
\hline WIN55212-2 & $1.9 \pm 0.1$ & $0.3 \pm 0.2$ & 6.8 & {$[143]$} \\
\hline JWH-015 & $164 \pm 22$ & $13.8 \pm 4.6$ & 11.9 & {$[107]$} \\
\hline JWH-120 & $1054 \pm 31$ & $6.1 \pm 0.7$ & 172.8 & {$[108]$} \\
\hline JWH-151 & $>10000$ & $30 \pm 1.1$ & $>333$ & {$[108]$} \\
\hline L768242 (GW405833) & $1917 \pm 381$ & $12 \pm 0.2$ & 159.8 & {$[144]$} \\
\hline AM1241(R) & $5000 \pm 300$ & $15.1 \pm 4.18$ & $>330$ & {$[146]$} \\
\hline AM1241(S) & $>10000$ & $658 \pm 44.2$ & $>15$ & {$[146]$} \\
\hline 21 & 4000 & 8 & 500 & [149] \\
\hline A-796260 & 845 & 4.37 & 193 & {$[150]$} \\
\hline \multicolumn{5}{|l|}{ Benzo[d] imidazole (Fig. 12) } \\
\hline 22 & - & $0.3^{f}$ & $4266^{\mathrm{f}}$ & {$[152]$} \\
\hline 23 & $>5000$ & 4.1 & 1220 & {$[153]$} \\
\hline 24 & $7500^{d}$ & $5.1^{\mathrm{d}}$ & 1471 & {$[154]$} \\
\hline 27 & $>10000^{f}$ & $11^{f}$ & $>909$ & {$[155]$} \\
\hline 26 & $>10000^{f}$ & $8.2^{f}$ & $>1220$ & {$[156]$} \\
\hline 27 & $17000^{f}$ & $8+2)$ & 2698 & {$[157]$} \\
\hline 28 (RQ-00202730) & $>25000^{f}$ & $19^{f}$ & $>1316$ & {$[158]$} \\
\hline Pyrazolo[3,4-b]pyridine (Fig. 13) & & 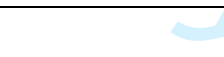 & & \\
\hline 29 & 4752 & 11.6 & 432 & [159] \\
\hline \multicolumn{5}{|l|}{ Imidazo[4,5-c]pyridine (Fig. 13) } \\
\hline 30 & $17000^{\mathrm{g}}$ & $58^{\mathrm{g}}$ & 293 & {$[160]$} \\
\hline 31 & $1068^{\mathrm{g}}$ & $11^{\mathrm{g}}$ & 97 & {$[160]$} \\
\hline \multicolumn{5}{|l|}{ Purine } \\
\hline 32 & & $37.5 \pm 4.8$ & 655 & {$[162]$} \\
\hline 33 & & $40.3 \pm 6.9$ & 4975 & {$[162]$} \\
\hline \multicolumn{5}{|l|}{ Isoxazolo[5,4-b]pyridine } \\
\hline 34 (MDA7) & $>10000$ & 422 & 24 & {$[163]$} \\
\hline$[6+6]$ heterocycles (Fig. 14) & & & & \\
\hline
\end{tabular}


Table 2. Cannabinoid receptor agonists studied using in vivo models of Alzheimer's disease

\begin{tabular}{|c|c|c|}
\hline Animal Model & Drugs & Ref. \\
\hline $\begin{array}{l}\text { Male Wistar rats and } \\
\text { Swyjs mice }\end{array}$ & AEA, noladin ether & {$[231]$} \\
\hline 5XFAD APP mice & $\Delta^{9}-\mathrm{THC}$ & [232] \\
\hline $\mathrm{A} \beta \mathrm{PP} / \mathrm{PS} 1$ mice & $\Delta^{9}-\mathrm{THC}, \mathrm{CBD}$ & {$[233]$} \\
\hline $\mathrm{PK}-/-/ T a u V L W$ & $\Delta^{9}-\mathrm{THC}, \mathrm{CBD}$ & {$[234]$} \\
\hline C57BL/6J mice & CBD & [235] \\
\hline Tg APP & CBD; WIN55,212-2 & [221] \\
\hline Male Wistar rats & WIN55,212-2 & {$[201]$} \\
\hline
\end{tabular}




\begin{tabular}{|c|c|c|}
\hline Male Wistar rats & WIN55,212-2 & [222] \\
\hline $\mathrm{Tg}$ APP & JWH-133; WIN55,212- & [236] \\
\hline Tg APP & JWH-133; WIN55,212- & {$[237]$} \\
\hline $\mathrm{A} \beta \mathrm{PP} / \mathrm{PS} 1$ & JWH-133 & [238] \\
\hline APP23/PS45 mice & HU-210 & [239] \\
\hline APP/PS1 mice & ß-caryophyllene & {$[240]$} \\
\hline $\begin{array}{l}\text { Male Sprague- } \\
\text { Dawdev_rats }\end{array}$ & MDA7 & {$[241]$} \\
\hline Tg APP, 5xFAD & NP137, NP43 & {$[186]$} \\
\hline
\end{tabular}


Table 3. Effects of CB2 agonists in animal models of cardiovascular disorders

\begin{tabular}{|c|c|c|c|c|}
\hline Disease/ in vivo model & $\begin{array}{l}\text { CB2 agonist } \\
\text { (Treatment) }\end{array}$ & $\begin{array}{l}\text { CB2 antagonist } \\
\text { (Block effect) }\end{array}$ & Results & $\operatorname{Ref}$ \\
\hline \multicolumn{5}{|l|}{ Atherosclerosis } \\
\hline Male $\mathrm{ApoE}^{-/-}$mice & $\mathrm{THC}$ & SR144528 & $\begin{array}{l}\Downarrow \text { Atherosclerotic lesions } \\
\Downarrow \text { Macrophage inflitration } \\
\Downarrow \text { Leukocyte adhesion }\end{array}$ & {$[254]$} \\
\hline Male $\mathrm{ApoE}^{-/-}$mice & WIN55212-2 & AM630 & $\begin{array}{l}\Downarrow \text { Atherosclerotic lesions } \\
\Downarrow \text { Macrophage inflitration } \\
\Downarrow_{\text {TNF- } \alpha \text {, IL-6 (inflammatory markers) }}\end{array}$ & [256] \\
\hline \multicolumn{5}{|l|}{ Myocardial I/R } \\
\hline $\begin{array}{l}\text { AMI induced by ligation of LAD } \\
\text { artery and I/R }\end{array}$ & HU308 & AM630 & $\begin{array}{l}\Downarrow \text { Infarct size } \\
\Downarrow \text { TNF- } \alpha \\
\Downarrow \text { ROS }\end{array}$ & [259] \\
\hline $\begin{array}{l}\text { Oclusion LADCA+reperfusion } \\
\text { rat model }\end{array}$ & WIN55212-2 & AM630 & $\begin{array}{l}\Downarrow \text { Myeloperoxidase } \\
\Downarrow \text { IL-1 } 1 \beta \text { band IL-8 } \\
\Downarrow \text { Infarct size }\end{array}$ & {$[265]$} \\
\hline $\begin{array}{l}\text { Oclusion LADCA+reperfusion } \\
\text { Mouse model }\end{array}$ & JWH-015 & SR144528 & $\Downarrow$ Infarct size & {$[261]$} \\
\hline $\begin{array}{l}\text { Oclusion LADCA+reperfusion } \\
\text { Mouse model }\end{array}$ & JWH-133 & AM630 & $\begin{array}{l}\Downarrow \text { Infarct size } \\
\Downarrow \text { Oxidative stress } \\
\Downarrow \text { Neutrophil inflitration }\end{array}$ & {$[266]$} \\
\hline $\begin{array}{l}\text { Oclusion LADCA+reperfusion } \\
\text { Mouse model and I/R CB2R }{ }^{-/-}\end{array}$ & JWH-133 & AM630 & $\begin{array}{l}\Downarrow \text { Infarct size (in I/R-WT) } \\
\text { No effect (in I/R CB2R } \mathrm{R}^{-/-} \text {) }\end{array}$ & [267] \\
\hline $\begin{array}{l}\text { Oclusion LADCA+reperfusion } \\
\text { rat model }\end{array}$ & JWH-133 & AM630 & $\begin{array}{l}\Downarrow \text { Infarct size } \\
\Downarrow \text { Apoptosis during ischemia/reperfusion } \\
\text { through inhibition of the pathway PI3K/Akt } \\
\text { signal }\end{array}$ & [268] \\
\hline $\begin{array}{l}\text { AMI induced by ligation of LAD } \\
\text { artery }\end{array}$ & AM1241 & - & $\begin{array}{l}\Downarrow \text { Fibrosis } \\
\Downarrow \text { TNF- } \alpha \text { and IL-6 } \\
\Downarrow \text { MDA (ROS) }\end{array}$ & [269] \\
\hline Oclusion LADCA+reperfusion & HU210 & SR144528 & $\Downarrow$ Infarct size & {$[270]$} \\
\hline
\end{tabular}




\begin{tabular}{|c|c|c|c|c|}
\hline \multirow{2}{*}{\multicolumn{5}{|c|}{$\Downarrow$ Incidence ventricular arrhythmias }} \\
\hline & & & & \\
\hline $\begin{array}{l}\text { MCAO } \\
\text { Mouse model }\end{array}$ & $0-3853 / 0-1966$ & - & $\begin{array}{l}\Downarrow \text { Cerebral infarction size } \\
\Uparrow \text { Motor function } \\
\Downarrow \text { Endothelial/leukocyte interactions }\end{array}$ & {$[271,272]$} \\
\hline $\begin{array}{l}\text { MCAO } \\
\text { Mouse model }\end{array}$ & $\begin{array}{l}\text { 0-1966 + SR141716 } \\
\text { (antagonist CB1) }\end{array}$ & SR144528 & $\begin{array}{l}W \downarrow \text { Cerebral infarction size } \\
\Uparrow \Uparrow \text { Motor function }\end{array}$ & [272] \\
\hline $\begin{array}{l}\text { MCAO } \\
\text { WT, CB2 } 2^{-/} \text {model and } \mathrm{CB}^{-/-} \\
\text {model }\end{array}$ & JWH-133 & - & $\begin{array}{l}\Downarrow \text { Cerebral infarction size }\left(\mathrm{WT}, \mathrm{CB} 1^{-/-}\right) \\
\Downarrow \text { Neutrophil recruiment } \\
\text { No effect in } \mathrm{CB}^{-/}\end{array}$ & [273] \\
\hline $\begin{array}{l}\text { MCAO } \\
\text { Mouse model }\end{array}$ & JWH-133 & & $\begin{array}{l}\Downarrow_{\text {Microglia and macrophage infiltration }} \\
\Downarrow_{\text {IL-6, MCP-1, MIP-1a, CCL-5 and TNF-a }} \\
\Downarrow_{\text {iNOS }}\end{array}$ & [274] \\
\hline $\begin{array}{l}\text { MCAO } \\
\text { Mouse model }\end{array}$ & WIN55212-2 & - & $\begin{array}{l}\Downarrow \text { Cerebral infarction size } \\
\Downarrow \quad \text { Microglial cells accumulation and } \\
\text { proliferation } \\
\Downarrow \text { Citokine expression }\end{array}$ & [275] \\
\hline
\end{tabular}



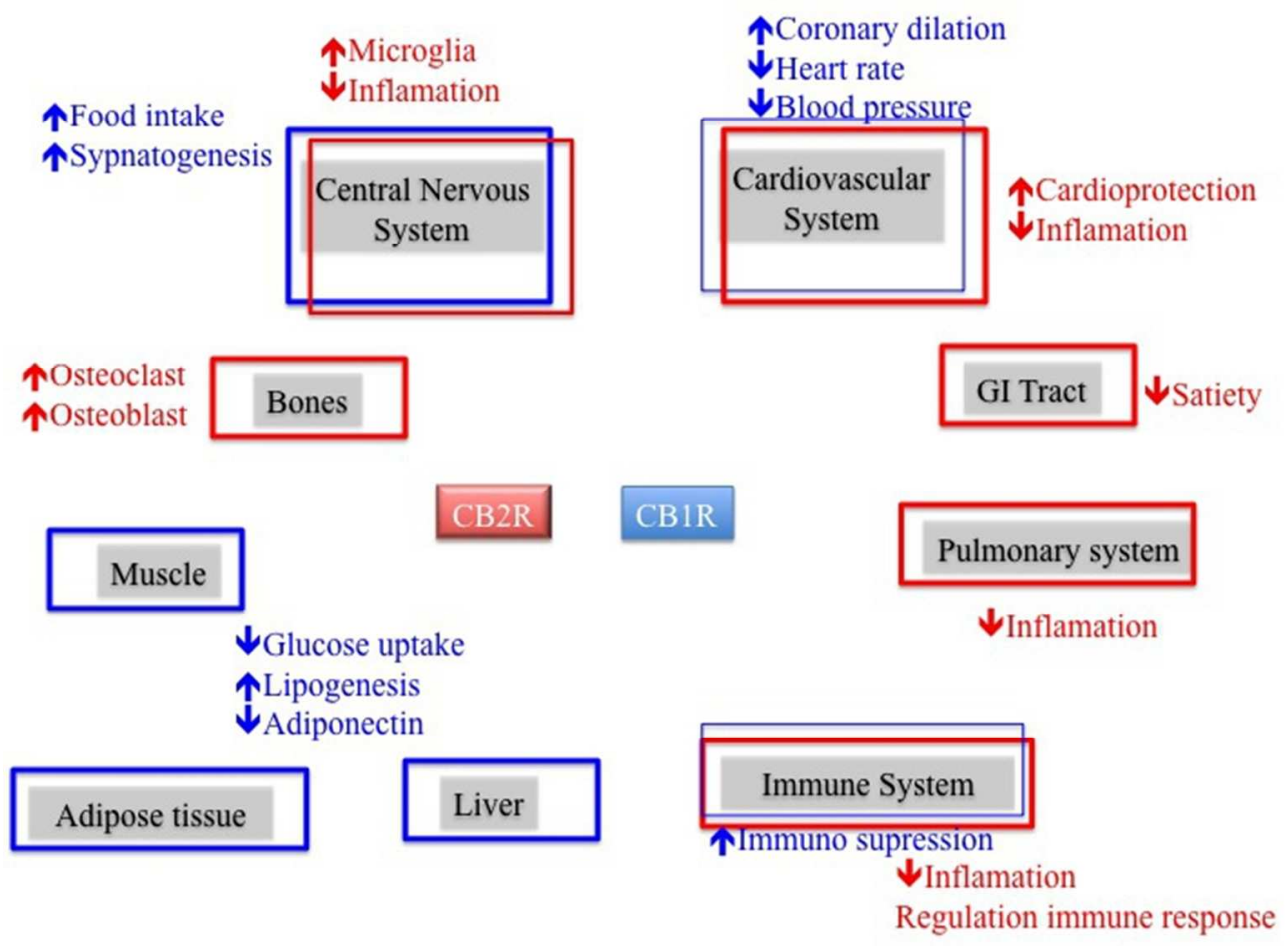

Schematic representation of the functional role of $\mathrm{CB} 1$ and $\mathrm{CB} 2$ receptors

$253 \times 191 \mathrm{~mm}(72 \times 72$ DPI $)$ 


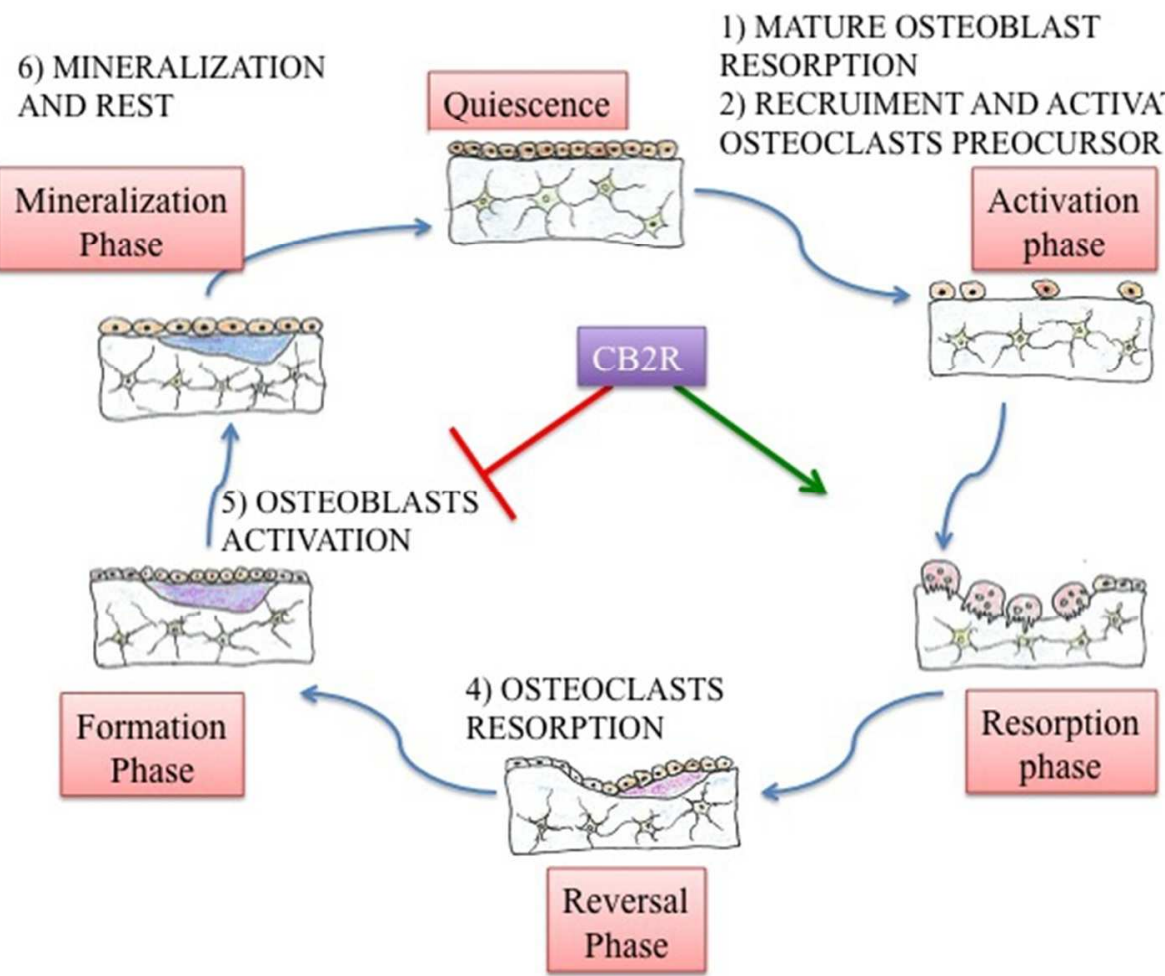

Bone formation phases

$228 \times 173 m m(72 \times 72$ DPI $)$ 
Table 1. Binding affinity and selectivity values of selected cannabinoid receptor agonists from CB1 and CB2 specific binding sites ${ }^{\mathrm{a}}$

\begin{tabular}{|c|c|c|c|c|}
\hline & $C B 1 K_{i}(n M)$ & $C B 2 K_{i}(n M)$ & CB1/CB2 & Ref. \\
\hline \multicolumn{5}{|c|}{ Endocannabinoids (Fig. 4) } \\
\hline Anandamide & $89 \pm 10$ & $371 \pm 102$ & & {$[143]$} \\
\hline $2 \mathrm{AG}$ & $472 \pm 55^{b}$ & $1400 \pm 172^{b}$ & & {$[62]$} \\
\hline Noladinether & $21.2 \pm 0.5^{\mathrm{a}}$ & $>3000^{\mathrm{a}}$ & & {$[66]$} \\
\hline \multicolumn{5}{|c|}{ Phytocannabinoid (Fig. 1) } \\
\hline$\Delta^{9}-\mathrm{THC}$ & 53.3 & 75.3 & & [61] \\
\hline$\Delta^{8}-\mathrm{THC}$ & $44 \pm 12$ & $44 \pm 17$ & 1.0 & {$[107]$} \\
\hline Cannabinol & 326 & 96.3 & 3.4 & {$[143]$} \\
\hline$\Delta^{9}-\mathrm{THCV}$ & 75.4 & 62.8 & 1.2 & [95] \\
\hline Cannabidiol & 4350 & 2860 & 1.5 & {$[143]$} \\
\hline (E)-ß-caryophyllene & $>10000$ & $155 \pm 4$ & 65 & [99] \\
\hline \multicolumn{5}{|l|}{ THC analogs (Fig. 8) } \\
\hline Nabilone & 1.84 & 2.19 & & {$[103]$} \\
\hline HU-210 & 0.06 & 0.52 & & [61] \\
\hline JWH-133 & $677 \pm 132$ & $3.4 \pm 1.0$ & 199 & {$[107]$} \\
\hline AM1714 & 400 & 0.82 & 490 & {$[110]$} \\
\hline \multicolumn{5}{|c|}{ CP 55940 analogs (Fig. 2) } \\
\hline CP 55940 & 3.72 & 2.55 & 1.5 & [61] \\
\hline HU-308 & $>10000^{b}$ & $22.7 \pm 3.9^{b}$ & $>440$ & [109] \\
\hline 1, O-1966A & $5055 \pm 984$ & $23 \pm 2.1$ & 220 & {$[111]$} \\
\hline 2 & 370 & 0.81 & 500 & {$[112]$} \\
\hline HU-910 & 1370 & 6 & 228 & [113] \\
\hline HU-433 & $>10000$ & 296 & $>34$ & {$[114]$} \\
\hline \multicolumn{5}{|c|}{ Five-member heterocyles (Fig. 9) } \\
\hline 3 (CBS055) & $4000^{c}$ & $2.9^{\mathrm{c}}$ & 1379 & {$[115]$} \\
\hline 4 & $2550^{d}$ & $5^{d}$ & 510 & {$[116]$} \\
\hline 5 (ALIAE809) & $>1000$ & $9.0 \pm 0.6$ & $>111$ & [117] \\
\hline 6 & $>3000$ & $60.8 \pm 6.9$ & $>49$ & {$[117]$} \\
\hline 7 & $3500^{c}$ & $13^{\mathrm{c}}$ & 269 & {$[118,119$} \\
\hline 9 & $220^{\mathrm{e}}$ & $1.7^{\mathrm{e}}$ & 129 & [120] \\
\hline 10 & $1430^{\mathrm{e}}$ & $7^{\mathrm{e}}$ & 204 & {$[121]$} \\
\hline
\end{tabular}




\begin{tabular}{|c|c|c|c|c|}
\hline 11 & $>30000^{\mathrm{f}}$ & $3.7^{\mathrm{f}}$ & $>8108$ & [122] \\
\hline \multicolumn{5}{|c|}{ Six-member heterocyles (Fig. 10, 11) } \\
\hline \multicolumn{5}{|l|}{ Piridine } \\
\hline 12 & $>30000$ & 79 & $>380$ & {$[125]$} \\
\hline 13 & $>2000^{f}$ & $10^{\mathrm{f}}$ & $>2000$ & {$[126]$} \\
\hline 14 (LEI-101) & $>10000$ & 32 & $>312$ & {$[127]$} \\
\hline 8 (S-777469) & 4627 & 36 & 129 & [128] \\
\hline 15 & $>3000$ & $20 \pm 3$ & $>150$ & [129] \\
\hline \multicolumn{5}{|l|}{ Piridazine (Fig. 11) } \\
\hline GW-842166X & $>30000^{f}$ & $63^{f}$ & $>476$ & {$[123,124$} \\
\hline 16 & $>30000^{f}$ & $79,4^{f}$ & $>378$ & [131] \\
\hline 17 & $8000^{f}$ & $10^{f}$ & 800 & [131] \\
\hline 18 & $>10000$ & $3.665 \pm 0.553$ & $>2729$ & [132] \\
\hline 19 & $>5000$ & 9 & $>550$ & {$[133]$} \\
\hline 20 & $2472^{\mathrm{d}}$ & $0.60^{\mathrm{d}}$ & 4120 & {$[136]$} \\
\hline \multicolumn{5}{|l|}{$[6+5]$ heterocycles } \\
\hline \multicolumn{5}{|l|}{ Indole (Fig. 6) } \\
\hline WIN55212-2 & $1.9 \pm 0.1$ & $0.3 \pm 0.2$ & 6.8 & {$[143]$} \\
\hline JWH-015 & $164 \pm 22$ & $13.8 \pm 4.6$ & 11.9 & {$[107]$} \\
\hline JWH-120 & $1054 \pm 31$ & $6.1 \pm 0.7$ & 172.8 & [108] \\
\hline JWH-151 & $>10000$ & $30 \pm 1.1$ & $>333$ & {$[108]$} \\
\hline L768242 (GW405833) & $1917 \pm 381$ & $12 \pm 0.2$ & 159.8 & [144] \\
\hline AM1241(R) & $5000 \pm 300$ & $15.1 \pm 4.18$ & $>330$ & {$[146]$} \\
\hline AM1241(S) & $>10000$ & $658 \pm 44.2$ & $>15$ & {$[146]$} \\
\hline 21 & 4000 & 8 & 500 & [149] \\
\hline A-796260 & 845 & 4.37 & 193 & {$[150]$} \\
\hline \multicolumn{5}{|c|}{ Benzo[d]imidazole (Fig. 12) } \\
\hline 22 & - & $0.3^{\mathrm{f}}$ & $4266^{\mathrm{f}}$ & {$[152]$} \\
\hline 23 & $>5000$ & 4.1 & 1220 & [153] \\
\hline 24 & $7500^{d}$ & $5.1^{\mathrm{d}}$ & 1471 & [154] \\
\hline 27 & $>10000^{f}$ & $11^{f}$ & $>909$ & {$[155]$} \\
\hline 26 & $>10000^{f}$ & $8.2^{\mathrm{f}}$ & $>1220$ & [156] \\
\hline 27 & $17000^{f}$ & $6.3^{\mathrm{f}}$ & 2698 & {$[157]$} \\
\hline 28 (RQ-00202730) & $>25000^{\mathrm{f}}$ & $19^{\mathrm{f}}$ & $>1316$ & {$[158]$} \\
\hline \multicolumn{5}{|c|}{ Pyrazolo[3,4-b]pyridine (Fig. 13) } \\
\hline 29 & 4752 & 11.6 & 432 & [159] \\
\hline
\end{tabular}




\begin{tabular}{|c|c|c|c|c|}
\hline \multicolumn{5}{|c|}{ Imidazo[4,5-c]pyridine (Fig. 13) } \\
\hline 30 & $17000^{g}$ & $58^{\mathrm{g}}$ & 293 & [160] \\
\hline 31 & $1068^{\mathrm{g}}$ & $11^{\mathrm{g}}$ & 97 & [160] \\
\hline \multicolumn{5}{|l|}{ Purine } \\
\hline 32 & & $37.5 \pm 4.8$ & 655 & {$[162]$} \\
\hline 33 & & $40.3 \pm 6.9$ & 4975 & [162] \\
\hline \multicolumn{5}{|c|}{ Isoxazolo[5,4-b]pyridine } \\
\hline 34 (MDA7) & $>10000$ & 422 & 24 & [163] \\
\hline \multicolumn{5}{|c|}{ [6+6] heterocycles (Fig. 14) } \\
\hline \multicolumn{5}{|l|}{ Quinoline } \\
\hline 35 & $>1000$ & $3.3 \pm 0.4$ & $>330$ & [164] \\
\hline 36 & $1925 \pm 179$ & $13.4 \pm 1.2$ & 143.7 & {$[165]$} \\
\hline 37 & 1220 & 6.3 & 1220 & [166] \\
\hline 38 & $>17000^{\mathrm{g}}$ & $6.1^{\mathrm{g}}$ & 2787 & {$[167]$} \\
\hline \multicolumn{5}{|l|}{ Naphthyridine } \\
\hline 39 (CB13) & $>1000$ & $50 \pm 4$ & $>20$ & [164] \\
\hline 40 (cis) & 1519 & 5.8 & 262 & {$[170]$} \\
\hline 41 & $1011 \pm 46.5$ & $1.36 \pm 0.053$ & 743 & [171] \\
\hline \multicolumn{5}{|c|}{ Tricyclyc heterocycles (Fig. 15) } \\
\hline \multicolumn{5}{|c|}{ Pyrido[4,3-b]indole } \\
\hline 42 & 120 & 9 & 13.3 & [172] \\
\hline \multicolumn{5}{|c|}{ Pyrazolo[4,3-c]quinoline } \\
\hline 43 & $>3000$ & 0.39 & $>77$ & [173] \\
\hline \multicolumn{5}{|c|}{ Benzo[b]quinolizine } \\
\hline $44(\mathrm{Sch} 35966)$ & $2633 \pm 829$ & $6.8 \pm 2.3$ & 387 & [174] \\
\hline \multicolumn{5}{|c|}{ Oxazino $[2,3,4-i j] q u i n o l i n e$} \\
\hline 45 (MT178) & $>10000$ & 8.12 & 1231 & [175] \\
\hline
\end{tabular}

${ }^{\text {a }}$ Affinity of compounds was evaluated using membranes from HEK-293 cells transfected and [ $\left.{ }^{3} \mathrm{H}\right] \mathrm{CP}-55,940$. ${ }^{\mathrm{b}}$ Experiments were performed with $\left[{ }^{3} \mathrm{H}\right] \mathrm{HU} 243$. ${ }^{\mathrm{c}}$ Binding affinity $\mathrm{IC}_{50}\left(\left[{ }^{3} \mathrm{H}\right] \mathrm{CP} 55,940\right.$ binding to rat spleen membranes). ${ }^{\mathrm{d}}$ Binding affinity $\mathrm{EC}_{50}\left(\left[{ }^{3} \mathrm{H}\right] \mathrm{CP} 55,940\right.$ binding to $\mathrm{CHO}$ cell membranes). ${ }^{\mathrm{e}} \mathrm{EC} 50[35 \mathrm{~S}] \mathrm{GTP} \gamma \mathrm{S}$ binding assay. ${ }^{\mathrm{f}} \mathrm{EC}_{50}$ values based on inhibition of forskolin-stimulated cAMP production in $\mathrm{CHO}$ cells expressing $\mathrm{CB} 2$ or $\mathrm{CB} 1$ receptor. ${ }^{\mathrm{g}} \mathrm{IC}_{50}(\mathrm{CHO}-\mathrm{K} 1$ cells, $\mathrm{AMP}$ detection). 
Table 2. Cannabinoid receptor agonists studied using in vivo models of Alzheimer's disease

\begin{tabular}{|c|c|c|}
\hline Animal Model & Drugs & Ref. \\
\hline $\begin{array}{l}\text { Male Wistar rats and } \\
\text { Swiss_mice }\end{array}$ & AEA, noladin ether & {$[231]$} \\
\hline 5XFAD APP mice & $\Delta^{9}-\mathrm{THC}$ & [232] \\
\hline $\mathrm{A} \beta \mathrm{PP} / \mathrm{PS} 1$ mice & $\Delta^{9}-\mathrm{THC}, \mathrm{CBD}$ & {$[233]$} \\
\hline $\mathrm{PK}-/-/ \mathrm{TauVLW}$ & $\Delta^{9}-\mathrm{THC}, \mathrm{CBD}$ & {$[234]$} \\
\hline C57BL/6J mice & $\mathrm{CBD}$ & {$[235]$} \\
\hline Tg APP & CBD; WIN55,212-2 & [221] \\
\hline Male Wistar rats & WIN55,212-2 & {$[201]$} \\
\hline Male Wistar rats & WIN55,212-2 & {$[222]$} \\
\hline Tg APP & JWH-133; WIN55,212- & {$[236]$} \\
\hline Tg APP & JWH-133; WIN55,212- & [237] \\
\hline $\mathrm{A} \beta \mathrm{PP} / \mathrm{PS} 1$ & JWH-133 & {$[238]$} \\
\hline APP23/PS45 mice & HU-210 & [239] \\
\hline APP/PS1 mice & B-caryophyllene & {$[240]$} \\
\hline $\begin{array}{l}\text { Male Sprague- } \\
\text { Dawlev_rats }\end{array}$ & MDA7 & {$[24$} \\
\hline Tg APP, 5xFAD & NP137, NP43 & [186] \\
\hline
\end{tabular}


Table 3. Effects of CB2 agonists in animal models of cardiovascular disorders

\begin{tabular}{|c|c|c|c|c|}
\hline Disease/ in vivo model & $\begin{array}{l}\text { CB2 agonist } \\
\text { (Treatment) }\end{array}$ & $\begin{array}{l}\text { CB2 antagonist } \\
\text { (Block effect) }\end{array}$ & Results & $\operatorname{Ref}$ \\
\hline \multicolumn{5}{|l|}{ Atherosclerosis } \\
\hline Male $\mathrm{ApoE}^{-/-}$mice & $\mathrm{THC}$ & SR144528 & $\begin{array}{l}\Downarrow \text { Atherosclerotic lesions } \\
\Downarrow \text { Macrophage inflitration } \\
\Downarrow \text { Leukocyte adhesion }\end{array}$ & {$[254]$} \\
\hline Male $\mathrm{ApoE}^{-/-}$mice & WIN55212-2 & AM630 & $\begin{array}{l}\Downarrow \text { Atherosclerotic lesions } \\
\Downarrow \text { Macrophage inflitration } \\
\Downarrow_{\text {TNF- } \alpha \text {, IL-6 (inflammatory markers) }}\end{array}$ & [256] \\
\hline \multicolumn{5}{|l|}{ Myocardial I/R } \\
\hline $\begin{array}{l}\text { AMI induced by ligation of LAD } \\
\text { artery and } I / R\end{array}$ & HU308 & AM630 & $\begin{array}{l}\Downarrow \text { Infarct size } \\
\Downarrow \text { TNF- } \alpha \\
\Downarrow \text { ROS }\end{array}$ & [259] \\
\hline $\begin{array}{l}\text { Oclusion LADCA+reperfusion } \\
\text { rat model }\end{array}$ & WIN55212-2 & AM630 & $\begin{array}{l}\Downarrow \text { Myeloperoxidase } \\
\Downarrow \text { IL-1 } 1 \beta \text { band IL-8 } \\
\Downarrow \text { Infarct size }\end{array}$ & {$[265]$} \\
\hline $\begin{array}{l}\text { Oclusion LADCA+reperfusion } \\
\text { Mouse model }\end{array}$ & JWH-015 & SR144528 & $\Downarrow$ Infarct size & {$[261]$} \\
\hline $\begin{array}{l}\text { Oclusion LADCA+reperfusion } \\
\text { Mouse model }\end{array}$ & JWH-133 & AM630 & $\begin{array}{l}\Downarrow \text { Infarct size } \\
\Downarrow \text { Oxidative stress } \\
\Downarrow \text { Neutrophil inflitration }\end{array}$ & {$[266]$} \\
\hline $\begin{array}{l}\text { Oclusion LADCA+reperfusion } \\
\text { Mouse model and I/R CB2R }\end{array}$ & JWH-133 & AM630 & $\begin{array}{l}\Downarrow \text { Infarct size (in I/R-WT) } \\
\text { No effect (in I/R CB2R }{ }^{-/-} \text {) }\end{array}$ & [267] \\
\hline $\begin{array}{l}\text { Oclusion LADCA+reperfusion } \\
\text { rat model }\end{array}$ & JWH-133 & AM630 & $\begin{array}{l}\Downarrow \text { Infarct size } \\
\Downarrow \text { Apoptosis during ischemia/reperfusion } \\
\text { through inhibition of the pathway PI3K/Akt } \\
\text { signal }\end{array}$ & [268] \\
\hline $\begin{array}{l}\text { AMI induced by ligation of LAD } \\
\text { artery }\end{array}$ & AM1241 & - & $\begin{array}{l}\Downarrow \text { Fibrosis } \\
\Downarrow \text { TNF- } \alpha \text { and IL-6 } \\
\Downarrow \text { MDA (ROS) }\end{array}$ & [269] \\
\hline Oclusion LADCA+reperfusion & HU210 & SR144528 & $\Downarrow$ Infarct size & {$[270]$} \\
\hline
\end{tabular}




\begin{tabular}{|c|c|c|c|c|}
\hline \multirow{2}{*}{\multicolumn{5}{|c|}{$\Downarrow$ Incidence ventricular arrhythmias }} \\
\hline & & & & \\
\hline $\begin{array}{l}\text { MCAO } \\
\text { Mouse model }\end{array}$ & $0-3853 / 0-1966$ & - & $\begin{array}{l}\Downarrow \text { Cerebral infarction size } \\
\Uparrow \text { Motor function } \\
\Downarrow \text { Endothelial/leukocyte interactions }\end{array}$ & {$[271,272]$} \\
\hline $\begin{array}{l}\text { MCAO } \\
\text { Mouse model }\end{array}$ & $\begin{array}{l}\text { 0-1966 + SR141716 } \\
\text { (antagonist CB1) }\end{array}$ & SR144528 & $\begin{array}{l}W \downarrow \text { Cerebral infarction size } \\
\Uparrow \Uparrow \text { Motor function }\end{array}$ & [272] \\
\hline $\begin{array}{l}\text { MCAO } \\
\text { WT, CB2 } 2^{-/} \text {model and } \mathrm{CB}^{-/-} \\
\text {model }\end{array}$ & JWH-133 & - & $\begin{array}{l}\Downarrow \text { Cerebral infarction size }\left(\mathrm{WT}, \mathrm{CB} 1^{-/-}\right) \\
\Downarrow \text { Neutrophil recruiment } \\
\text { No effect in } \mathrm{CB}^{-/}\end{array}$ & [273] \\
\hline $\begin{array}{l}\text { MCAO } \\
\text { Mouse model }\end{array}$ & JWH-133 & & $\begin{array}{l}\Downarrow_{\text {Microglia and macrophage infiltration }} \\
\Downarrow_{\text {IL-6, MCP-1, MIP-1a, CCL-5 and TNF-a }} \\
\Downarrow_{\text {iNOS }}\end{array}$ & [274] \\
\hline $\begin{array}{l}\text { MCAO } \\
\text { Mouse model }\end{array}$ & WIN55212-2 & - & $\begin{array}{l}\Downarrow \text { Cerebral infarction size } \\
\Downarrow \quad \text { Microglial cells accumulation and } \\
\text { proliferation } \\
\Downarrow \text { Citokine expression }\end{array}$ & [275] \\
\hline
\end{tabular}

